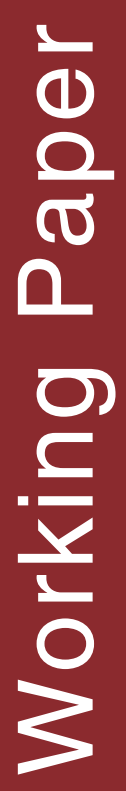

Riyandoko, Endri Martini, Aulia Perdana, Amirah Yumn, James M Roshetko 



\section{Situasi Terkini, Tantangan dan Kebutuhan Pelaksanaan Penyuluhan Kehutanan dan Agroforestri di Indonesia}

Riyandoko, Endri Martini, Aulia Perdana, Amirah Yumn, James M Roshetko 


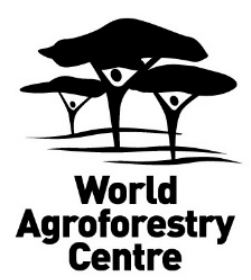

\section{Correct citation:}

Riyandoko, Martini E, Perdana A, Yumn A, Roshetko JM. 2016. Situasi Terkini, Tantangan dan Kebutuhan dari Pelaksanaan Penyuluhan Kehutanan dan Agroforestri di Indonesia. Working Paper no. 239. Bogor, Indonesia: World Agroforestry Centre (ICRAF) Southeast Asia Regional Program. DOI:

http://dx.doi.org/10.5716/WP16142.PDF

Titles in the Working Paper series aim to disseminate interim results on agroforestry research and practices, and stimulate feedback from the scientific community. Other publication series from the World Agroforestry Centre include: Technical Manuals, Occasional Papers and the Trees for Change Series.

Published by the World Agroforestry Centre

ICRAF Southeast Asia Regional Program

JL. CIFOR, Situ Gede, Sindang Barang, Bogor 16680

PO Box 161, Bogor 16001, Indonesia

Tel: +622518625415

Fax: +622518625416

Email: icraf-indonesia@cgiar.org

ICRAF Southeast Asia website: http://www.worldagroforestry.org/region/southeast-asia/

(C) World Agroforestry Centre 2016

Working Paper 239

\section{Photographs:}

The views expressed in this publication are those of the author(s) and not necessarily those of the World Agroforestry Centre.Articles appearing in this publication may be quoted or reproduced without charge, provided the source is acknowledged. All images remain the sole property of their source and may not be used for any purpose without written permission of the source. 


\section{Tentang Penulis}

Riyandoko adalah peneliti penyuluhan agroforestri untuk proyek penelitian kayu dan hasil hutan bukan kayu di World Agroforestry Centre (ICRAF) sejak tahun 2015. Sejak tahun 2003, beliau bekerja dalam bidang pendidikan, penyuluhan dan pemberdayaan masyarakat di Sumatera, Jawa, Kalimantan dan Sulawesi. Riyandoko menyandang gelar Sarjana Peternakan dari Universitas Wangsa Manggala Yogyakarta pada tahun 2006.

Endri Martini saat ini bekerja di World Agroforestry Centre (ICRAF) sebagai peneliti penyuluhan agroforestri sejak tahun 2011. Beliau bergabung dengan ICRAF sejak tahun 2001 dan bekerja dalam berbagai topik agroforestri seperti konservasi keanekaragaman hayati dan pemberdayaan masyarakat. Gelar S1 diperolehnya dari Jurusan Silvikultur di Fakultas Kehutanan, Institut Pertanian Bogor. Gelar S2 bidang Sumber Daya Alam dan Pengelolaan Lingkungan diperolehnya dari University of Hawaii at Manoa, Hawaii, USA.

Aulia Perdana adalah peneliti rantai nilai, pasar, dan UKM yang bekerja di World Agroforestry Centre (ICRAF) sejak tahun 2010. Aulia berpengalaman lebih dari sepuluh tahun di kegiatan penelitian dan pengembangan rantai nilai produk dan pemasaran, serta pengembangan usaha kecil. Pengalamannya dalam mengelola kegiatan penelitian dan pengembangan meliputi Jambi, Jawa Tengah, Kalimantan Selatan dan Kalimantan Tengah, Sulawesi, kepulauan Nusa Tenggara, dan Nepal. Saat ini ia memimpin proyek penelitian empat tahun (2013-2016) terkait integrasi produksi dan strategi pemasaran untuk produk kayu dan non-kayu di Indonesia. Aulia memperoleh gelar Master of Science di Bidang Manajemen dari Universitas Gadjah Mada.

Amirah Yumn adalah riset asisten Kanoppi projek yang saat ini bekerja di Center for International Forestry Research (CIFOR), sebelumnya beliau bekerja di World Agroforestry Centre sebagai Statistician dalam projek yang sama. Beliau bergabung dengan Kanoppi projek pada awal tahun 2014. Beliau banyak bekerja dengan analisa data pada bidang silvikultur, pemasaran, kebijakan dan penyuluhan. Gelar S1 diperolehnya dari Jurusan Statistika di Fakultas Matematika dan Ilmu Pengetahuan Alam, Institut Pertanian Bogor.

James M Roshetko adalah peneliti di bidang Sistem Agroforestri yang saat ini juga memiliki posisi sebagai Kepala Unit Trees and Market -World Agroforestry Centre (ICRAF) Asia Tenggara. Beliau memiliki pengalaman kerja 37 tahun, termasuk 19 tahun di Indonesia dan 28 di Asia Tenggara dan Asia Selatan. Fokus penelitiannya saat ini adalah sistem pertanian skala kecil yang berbasis pohon sebagai sebuah sistem pengelolaan pertanian dan sumber daya alam berkelanjutan yang berkontribusi secara nyata terhadap pengembangan ekonomi lokal sekaligus pelestarian lingkungan secara global. James menyandang gelar doktor dalam bidang Ilmu Bumi dan Pengelolaan Sumber Daya Alam dari 
University of Copenhagen, Denmark and gelar master dalam bidang Pengelolaan Hutan dan Agoroforestri dari Michigan State University, USA. 


\section{Abstrak}

Kayu dan hasil hutan bukan kayu (HHBK) adalah hasil hutan dan kebun agroforestri yang berpotensi sebagai sumber penghidupan petani. Apabila pengelolaan dilakukan secara berkelanjutan, produk tersebut dapat memberikan peningkatan pendapatan bagi petani. Guna mencapai pengelolaan yang berkelanjutan, petani membutuhkan akses ke informasi yang benar dan tepat melalui penyuluhan. Namun di wilayah terpencil, petani kecil dengan luas lahan yang sempit memiliki keterbatasan dalam mengakses informasi tersebut. Studi ini dilakukan dengan tujuan untuk memahami sistem penyuluhan kehutanan yang efektif dalam mendukung peningkatan akses informasi bagi petani hutan di Indonesia, terutama tentang pengembangan kayu dan HHBK sebagai sumber penghasilan petani. Wawancara dilakukan terhadap 500 petani, selain itu enam diskusi kelompok terarah dilakukan untuk membahas pendekatan penyuluhan kehutanan yang dilakukan baik oleh pihak pemerintah maupun swasta.

Observasi lapangan terhadap sistem penyuluhan kehutanan juga dilakukan untuk mengumpulkan data kualitatif dan kuantitatif yang mendukung. Studi dilakukan di tiga kabupaten yang tersebar di tiga provinsi di Indonesia, yaitu: Gunungkidul, Daerah Istimewa Yogyakarta; Sumbawa, Nusa Tenggara Barat; dan Timor Tengah Selatan, Nusa Tenggara Timur. Hasil menunjukkan bahwa sistem penyuluhan kehutanan saat ini masih belum optimal, terutama disebabkan oleh: a) kurangnya jumlah penyuluh pemerintah di lapangan untuk bidang kehutanan; b) kurangnya materi penyuluhan kehutanan yang disampaikan kepada petani; dan c) kurangnya anggaran penyuluhan kehutanan yang dialokasikan di tingkat kabupaten. Di beberapa wilayah studi yang terletak di daerah terpencil, peran penyuluh swasta cukup besar dalam menyebarluaskan informasi kehutanan. Untuk kedepannya, pelaksanaan penyuluhan kehutanan perlu dilakukan secara kolaboratif antara antara penyuluh pemerintah, penyuluh swadaya dan penyuluh swasta sehingga dapat mendukung efektifitas penyebarluasan informasi dan pembangunan kapasitas petani dalam pengelolaan hutan yang berkelanjutan.

Kata kunci: Gunungkidul, Sumbawa, Timor Tengah Selatan, Penyuluh Swasta, Penyuluh Swadaya 


\section{Ucapan Terima Kasih}

Studi ini terlaksana atas pendanaan dari Australian Centre for International Agricultural Research (ACIAR) pada proyek Pengembangan Produksi dan Strategi Pemasaran Kayu dan Hasil Hutan Bukan Kayu Untuk Peningkatan Penghidupan Petani Di Indonesia (KANOPPI). Penulis mengucapkan terima kasih kepada petani dari Desa Karangduwet, Desa Bejiharjo, Desa Bosen, Desa Fatumnasi, Desa Pelat dan Desa Batudulang; lembaga penyuluhan di Kabupaten Gunungkidul, Kabupaten Sumbawa dan Kabupaten Timor Tengah Selatan; Perkumpulan ARUPA, Perhimpunan Shorea; Helen Keller International-Indonesia selaku responden dan narasumber dalam studi. Rekan-rekan anggota proyek dari Dinas Kehutanan Kabupaten Gunungkidul, Kabupaten Timor Tengah Selatan, Kabupaten Sumbawa, CIFOR, WWF Indonesia Program Nusa Tenggara, Kelompok Kerja Hutan Lestari Kabupaten Gunungkidul, dan Universitas Mataram Nusa Tenggara Barat yang telah membantu dan memfasilitasi dalam pengumpulan data. 


\section{Daftar Isi}

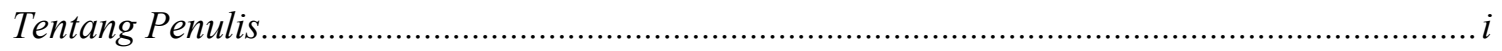

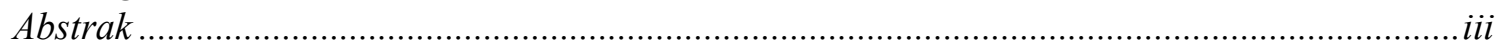

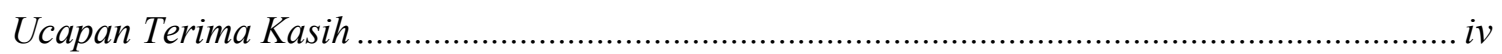

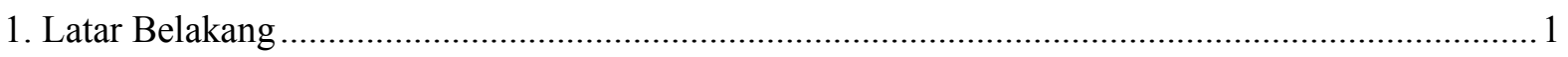

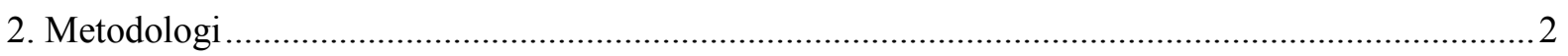

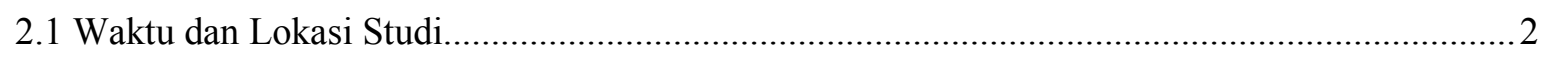

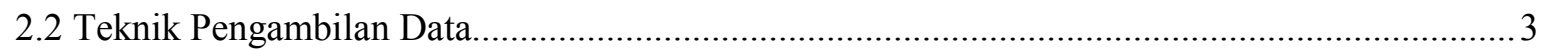

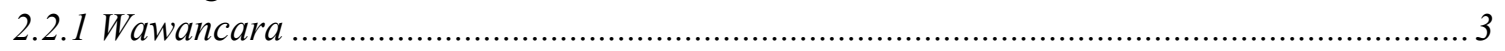

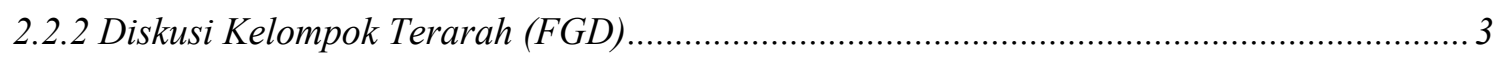

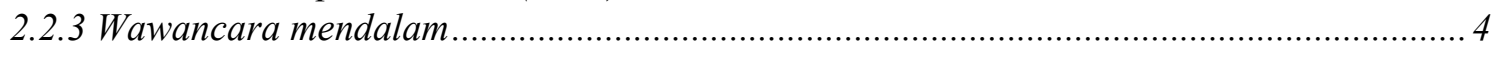

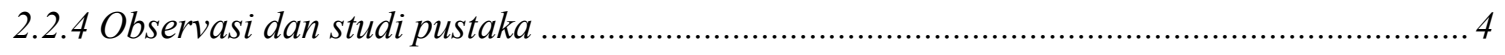

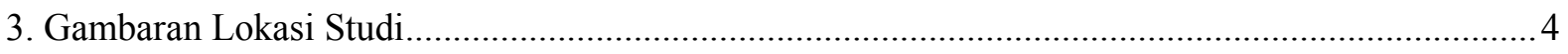

3.1 Kabupaten Gunungkidul, Provinsi Daerah Istimewa Yogyakarta ............................................. 4

3.2 Kabupaten Sumbawa, Provinsi Nusa Tenggara Barat ............................................................ 6

3.3 Kabupaten Timor Tengah Selatan, Nusa Tenggara Timur ......................................................

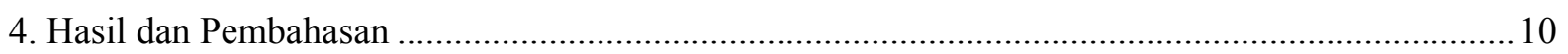

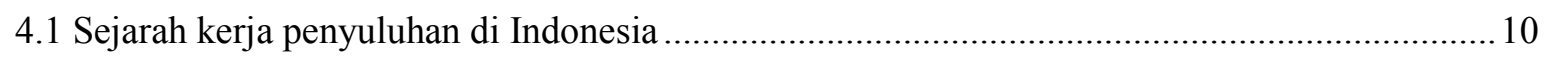

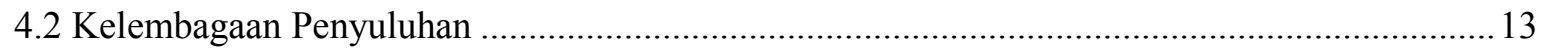

4.2.1 Kelembagaan Penyuluhan Pemerintah Pada Tingkat Kabupaten .................................... 14

4.2.2 Kelembagaan Penyuluhan Pemerintah Pada Tingkat Kecamatan ................................... 15

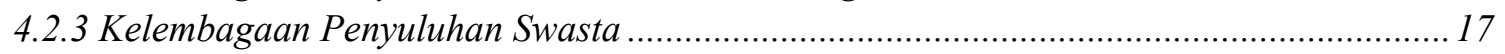

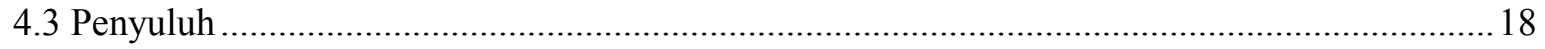

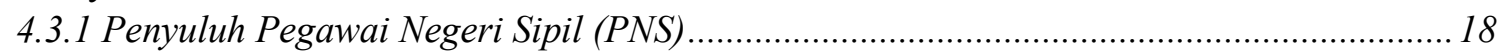

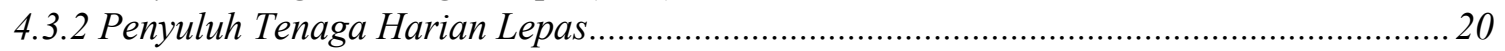

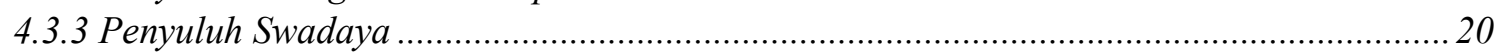

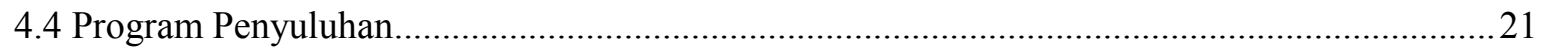

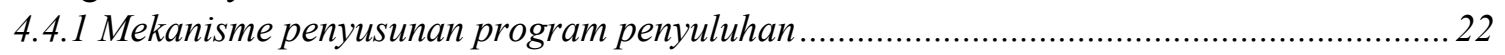

4.4.2 Program Penyuluhan Kehutanan Kabupaten Gunungkidul..............................................2. 23

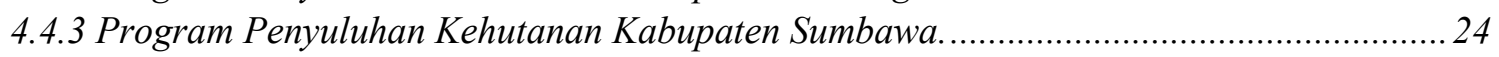

4.4.4 Program Penyuluhan Kehutanan Kabupaten Timor Tengah Selatan............................... 24

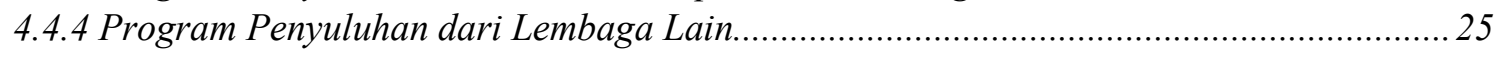

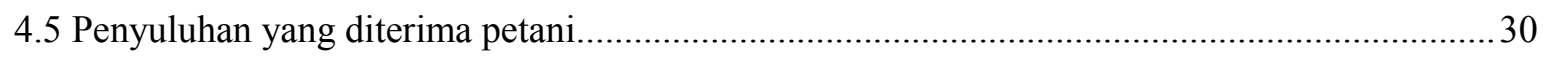

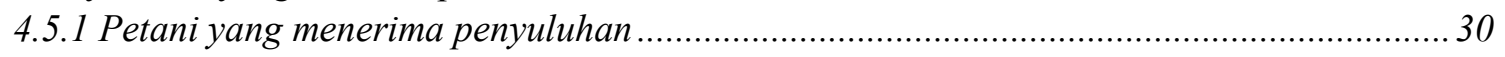

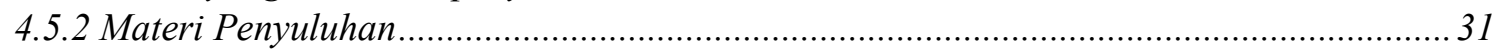

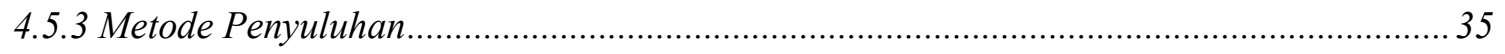

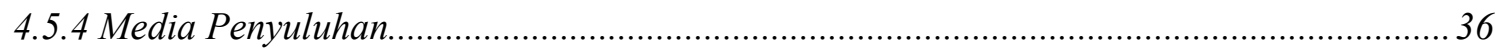

4.5.6 Sumber informasi bagi petani yang tidak menerima penyuluhan ..................................... 38

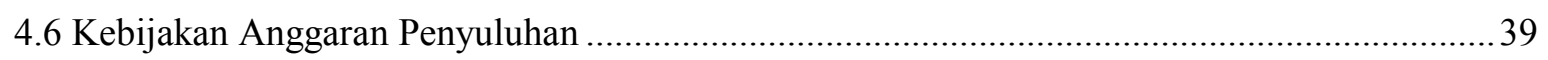

4.6.1 Anggaran Penyuluhan Kabupaten Gunungkidul, Daerah Istimewa Yogyakarta................ 39

4.6.2 Anggaran Penyuluhan Kabupaten Sumbawa, Nusa Tenggara Barat ............................... 40 
4.7 Kebutuhan dan Tantangan Penyuluhan Kehutanan dan Agroforestri........................................41

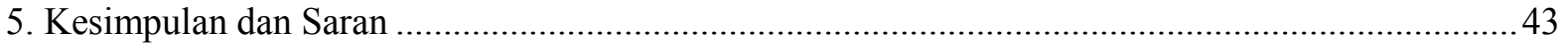

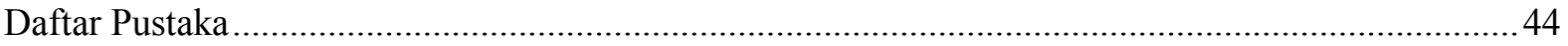

Lampiran 1. Keadaan wilayah, tujuan penyuluhan, materi dan metode pada program penyuluhan di Kabupaten Gunungkidul tahun 2014............................................................ 46

Lampiran 2. Keadaan wilayah, tujuan penyuluhan, materi dan metode pada program

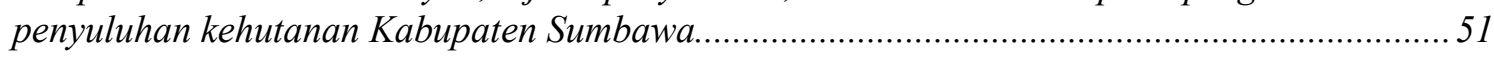




\section{Daftar Tabel}

Tabel 1. Produksi hasil hutan rakyat di Kabupaten Gunungkidul tahun 2012-2013

Tabel 2. Produksi kayu dan hasil hutan bukan kayu di Kabupaten Timor Tengah Selatan tahun 2011-2013

Tabel 3. Sejarah penyuluhan pertanian di Indonesia dari tahun 1900 hingga sekarang (2016).

Tabel 4. Kelembagaan Penyuluhan di Kabupaten Gunungkidul, Kabupaten Sumbawa dan Kabupaten Timor Tengah Selatan.

Tabel 5. Kelembagaan Penyuluhan Swasta di Kabupaten Gunungkidul, Kabupaten Sumbawa dan Kabupaten Timor Tengah Selatan.

Tabel 6. Materi penyuluhan yang diterima petani di Kabupaten Gunungkidul, Kabupaten

Sumbawa dan Kabupaten Timor Tengah Selatan

Tabel 7. Hasil identifikasi materi penyuluhan yang pernah diterima petani dalam 5 tahun terakhir di Kabupaten Gunungkidul, Kabupaten Sumbawa dan Kabupaten Timor Tengah Selatan.

\section{Daftar Gambar}

Gambar 1. Peta Kabupaten Gunungkidul, Daerah Istimewa Yogyakarta, Indonesia

Gambar 2. Peta Kabupaten Sumbawa, Nusa Tenggara Barat, Indonesia.

Gambar 3. Peta Kabupaten Timor Tengah Selatan, Nusa Tenggara Timur, Indonesia.

Gambar 4. Diagram kelembagaan penyuluhan pemerintah di Indonesia berdasarkan Peraturan Presiden No. 154/2014 tentang kelembagaan penyuluhan.

Gambar 5. Jumlah penyuluh PNS di Kabupaten Sumbawa, Kabupaten Gunungkidul dan Kabupaten Timor Tengah Selatan berdasarkan usia dan jenis kelamin.

Gambar 6. Jumlah penyuluh kehutanan di Kabupaten Gunungkidul, Kabupaten Sumbawa dan Kabupaten Timor Tengah Selatan berdasarkan tingkat pendidikan dan jenis kelamin.

Gambar 7. Petani yang pernah mengikuti penyuluhan dalam lima tahun terakhir di Kabupaten Gunungkidul, Kabupaten Sumbawa, Kabupaten Timor Tengah Selatan.

Gambar 8. Metode penyuluhan yang digunakan pada Kabupaten Gunungkidul, Kabupaten Sumbawa dan Kabupaten Timor Tengah Selatan.

Gambar 9. Bentuk media penyuluhan yang digunakan dalam kegiatan penyuluhan di Kabupaten Gunungkidul, Kabupaten Sumbawa dan Kabupaten Timor Tengah Selatan.....

Gambar 10. Sumber Informasi tentang pertanian dan kehutanan bagi petani yang tidak menerima penyuluhan. 



\section{Latar Belakang}

Kayu dan Hasil Hutan Bukan Kayu (HHBK) merupakan hasil agroforestri dan kehutanan yang berpotensi sebagai pilihan sumber penghidupan bagi petani hutan. Dari penelitian sebelumnya, kayu dan HHBK berkontribusi nyata dalam mendukung pendapatan petani. Menurut Rohadi et al (2012), penjualan kayu jati yang ditanam di kebun agroforestri oleh petani di Gunungkidul, Daerah Istimewa Yogyakarta berkontribusi sekitar 12\% untuk pendapatan rumah tangga. HHBK merupakan merupakan sumber penghasilan jangka pendek dan menengah yang penting bagi masyarakat pedesaan. Dari laporan proyek penelitian Smallholder Agribusiness Development Initiative (SADI)- Australian Centre for International Agriculture Research (ACIAR) menyatakan bahwa petani di Timor Barat belum menjadikan madu sebagai sumber penghasilan utama mereka, akan tetapi, saat ini lembaga penelitian merasa bahwa madu merupakan HHBK yang potensial sebagai sumber pendapatan keluarga, oleh karena itu perlu dilakukan penelitian lebih dalam untuk mendukung peningkatan produksi madu dengan menggunakan lebah lokal (Nimwegen et al 2009).

Praktik penanaman tanaman jati yang dikombinasikan dengan HHBK di Kabupaten Gunungkidul telah diinisiasi oleh petani sejak pertengahan tahun 1960-an. Data survei rumah tangga yang dilakukan ACIAR Teak Project tahun 2008 di Gunungkidul, menunjukkan bahwa sebagian besar petani menanam jati di lahan dengan luas kurang dari satu hektar (63\%) dan banyak juga yang menanam di lahan kurang dari 0,5 hektar (37\%). Hanya sebanyak $12 \%$ yang menanam jati di lahan lebih dari dua hektar. Petani Gunungkidul juga menanam pohon jati di lahan yang penggunaan utamanya untuk pertanian tanaman pangan (Rohadi et al 2012). Tanaman pangan yang sering ditumpangsarikan dengan jati adalah jagung, padi, singkong, dan tanaman berimpang (jahe, kunyit, kencur, temulawak).

Pengelolaan kayu dan HHBK jika dilakukan secara berkelanjutan akan dapat memberikan peningkatan dan penghasilan yang terus-menerus bagi petani. Informasi tentang produksi, pengolahan, pemasaran dan kebijakan yang berkaitan dengan kayu dan HHBK menjadi sebuah kebutuhan bagi petani dalam pengelolaan yang berkelanjutan dan menguntungkan. Petani di Gunungkidul masih belum banyak menerapkan teknik silvikultur (budidaya hutan), yang menyebabkan rendahnya kualitas kayu yang dihasilkan dari kebun petani. Kurangnya motivasi petani dalam melakukan teknik silvikultur dikarenakan terbatasnya pengetahuan, modal serta kurangnya intensif pasar (Roshetko et al 2013). Oleh karena itu, akses petani terhadap informasi yang akurat dan dapat dipercaya, diharapkan dapat membantu meningkatkan pengelolaan sumber daya alam yang berkelanjutan.

Penyuluhan merupakan salah satu cara petani mengakses informasi yang akurat dan dapat dipercaya. Dalam Undang-Undang Republik Indonesia No 16 Tahun 2006 (UU No 16/2006), penyuluhan 
merupakan proses pembelajaran bagi petani dan pelaku usaha lainnya agar mereka mau, mampu menolong dan mengorganisasi dirinya dalam mengakses informasi pasar, teknologi, permodalan, dan sumberdaya lainnya, sebagai upaya untuk meningkatkan produktivitas, efisiensi usaha, pendapatan, dan kesejahteraannya, serta meningkatkan kesadaran dalam pelestarian fungsi lingkungan hidup.

Studi ini merupakan bagian dari Proyek “ Development of timber and nontimber forest product' production and marketing strategies for improvement of smallholders' livelihoods in Indonesia" yang dilakukan oleh The World Agroforestry Center (ICRAF) dan Center of International Forestry Research (CIFOR) yang didanai oleh Australian Center for International Agriculture Research (ACIAR). Studi ini dilakukan untuk menjawab pertanyaan tentang karakteristik dari program penyuluhan pengelolaan kayu dan HHBK, produksi dan pemasarannya. Tujuan dari studi adalah memahami sistem penyuluhan kehutanan dan agroforestri yang mendukung pengembangan kayu dan HHBK sebagai alternatif sumber penghasilan bagi petani kecil di Indonesia. Harapannya hasil dari studi ini dapat membantu memetakan kebutuhan dan tantangan dari penciptaan penyuluhan kehutanan dan agroforestri yang efektif di Indonesia.

\section{Metodologi}

\subsection{Waktu dan Lokasi Studi}

Pengambilan data dilakukan melalui dua tahapan yaitu (i) pada September-Oktober 2013 untuk mengetahui persepsi petani hutan terhadap penyuluhan kehutanan yang pernah diterimanya, dan (ii) Januari-Maret 2015 untuk mengetahui persepsi lembaga-lembaga penyuluhan kehutanan di lokasi studi. Studi dilakukan di tiga kabupaten yang tersebar di tiga provinsi di Indonesia yaitu: Kabupaten Gunungkidul, Daerah Istimewa Yogyakarta; Kabupaten Sumbawa, Nusa Tenggara Barat; Kabupaten Timor Tengah Selatan, Nusa Tenggara Timur. Ketiga tempat ini dianggap mewakili tiga model pengelolaan produk kayu dan hasil hutan bukan kayu (HHBK) di Indonesia. Kabupaten Gunungkidul adalah wilayah yang mewakili model pengelolaan kayu dan HHBK yang didomestikasi (budidaya); Kabupaten Sumbawa adalah wilayah yang mewakili model pengelolaan ekstraksi kayu dari hutan dan HHBK domestikasi; dan Kabupaten Timor Tengah Selatan adalah wilayah yang mewakili model pengelolaan kayu domestikasi (penanaman) dan HHBK ektraksi dari hutan. 


\subsection{Teknik Pengambilan Data}

\subsubsection{Wawancara}

Wawancara dilakukan terhadap 500 petani dalam survei rumah tangga. Wawancara ini dilakukan untuk mendapatkan informasi mengenai: (i) Kegiatan penyuluhan yang diterima masyarakat dalam lima tahun terakhir; (ii) Proses penyebaran informasi selain melalui kegiatan penyuluhan formal; dan (iii) Harapan petani tentang penyuluhan kehutanan dan agroforestri. Wawancara dengan petani ini dilakukan di dua desa untuk masing-masing kabupaten yaitu: Desa Bejiharjo dan Desa Karangduwet di Kabupaten Gunungkidul; Desa Pelat dan Desa Batudulang di Kabupaten Sumbawa; Desa Bosen dan Desa Fatumnasi di Kabupaten Timor Tengah Selatan. Responden diambil secara acak, dimana jumlah masing-masing responden per kabupaten sebagai berikut: Kabupaten Gunungkidul 102 petani (perempuan: 36,3\%, laki-laki: 63,7\%); Kabupaten Sumbawa 167 petani (perempuan: 20,4\%, laki-laki: 79,6\%); Kabupaten Timor Tengah Selatan 129 petani (perempuan: 10,9\%, laki-laki: 89,1\%).

\subsubsection{Diskusi Kelompok Terarah (FGD)}

Dalam studi ini, 11 FGD dilakukan di lima kelompok penyuluh dan enam kelompok petani. FGD dengan penyuluh ditujukan untuk mendapatkan informasi mengenai: kelembagaan penyuluhan, program penyuluhan, kuantitas dan kualitas penyuluh, materi penyuluhan, metode penyuluhan, dan anggaran penyuluhan di masing-masing lokasi studi. Kelima kelompok FGD penyuluh tersebut adalah:

- Balai Penyuluhan Pertanian, Perikanan dan Kehutanan (BP3K) Kecamatan Paliyan, Kabupaten Gunungkidul;

- BP3K Kecamatan Karangmojo, Kabupaten Gunungkidul;

- BP3K Kecamatan Mollo Utara, Kabupaten Timor Tengah Selatan;

- Badan Pelaksana Penyuluhan Pertanian, Perikanan dan Kehutanan (BP4K) Kabupaten Timor Tengah Selatan;

- $\quad$ BP4K Kabupaten Sumbawa

Sedangkan FGD dengan petani dilakukan di semua desa lokasi studi. FGD petani ditujukan untuk mengkonfirmasi informasi yang diperoleh melalui wawancara rumah tangga dengan petani di masingmasing desa studi. Setiap FGD diikuti oleh 5-10 peserta, dengan 18\% peserta perempuan. 


\subsubsection{Wawancara mendalam}

Wawancara mendalam dilakukan dengan responden kunci yaitu: kepala badan pelaksana penyuluhan kabupaten; koordinator penyuluh BP3K kecamatan; lembaga penyuluh swasta; lembaga penyuluh swadaya; lembaga penelitian/perguruan tinggi. Wawancara mendalam ini ditujukan untuk mendapatkan data lebih detail mengenai kelembagaan penyuluhan, program penyuluhan, kuantitas dan kualitas penyuluh, materi penyuluhan, metode penyuluhan, dan anggaran penyuluhan pada masing-masing lokasi studi.

\subsubsection{Observasi dan studi pustaka}

Observasi dilakukan untuk memastikan dan mengurangi bias antara data wawancara, FGD dengan yang terjadi di lapangan. Observasi juga ditujukan untuk melengkapi data baik secara kualitas dan kuantitas. Hal-hal yang diobservasi antara lain:

- Bentuk kebun dan sistem pertanian kehutanan yang ada di lokasi studi.

- Media penyuluhan yang diproduksi dan digunakan oleh penyuluh.

- Media penyuluhan yang pernah diterima oleh petani.

Studi pustaka yang dilakukan adalah mempelajari dokumen-dokumen yang berhubungan dengan sistem dan teknik penyuluhan di Indonesia seperti: kebijakan yang berhubungan dengan penyuluhan; program penyuluhan dari masing-masing lokasi studi; paper dan artikel penyuluhan.

\section{Gambaran Lokasi Studi}

\subsection{Kabupaten Gunungkidul, Provinsi Daerah Istimewa Yogyakarta}

Gunungkidul adalah satu dari lima kabupaten/kota di Daerah Istimewa Yogyakarta. Kabupaten Gunungkidul berada di timur Kota Yogyakarta, dengan pusat pemerintahan dan perekonomian kabupaten terletak di Kota Wonosari. Kabupaten Gunungkidul memiliki luas wilayah 148.536 ha yang dibagi dalam 18 kecamatan dan 144 desa/kelurahan. Menurut estimasi sensus penduduk nasional tahun 2010, jumlah penduduk di Kabupaten Gunungkidul pada tahun 2013 sebanyak 683.735 jiwa dengan rasio jenis kelamin 330.461 laki-laki dan 353.274 perempuan (Badan Pusat Statistik (BPS) Gunungkidul 2014). 


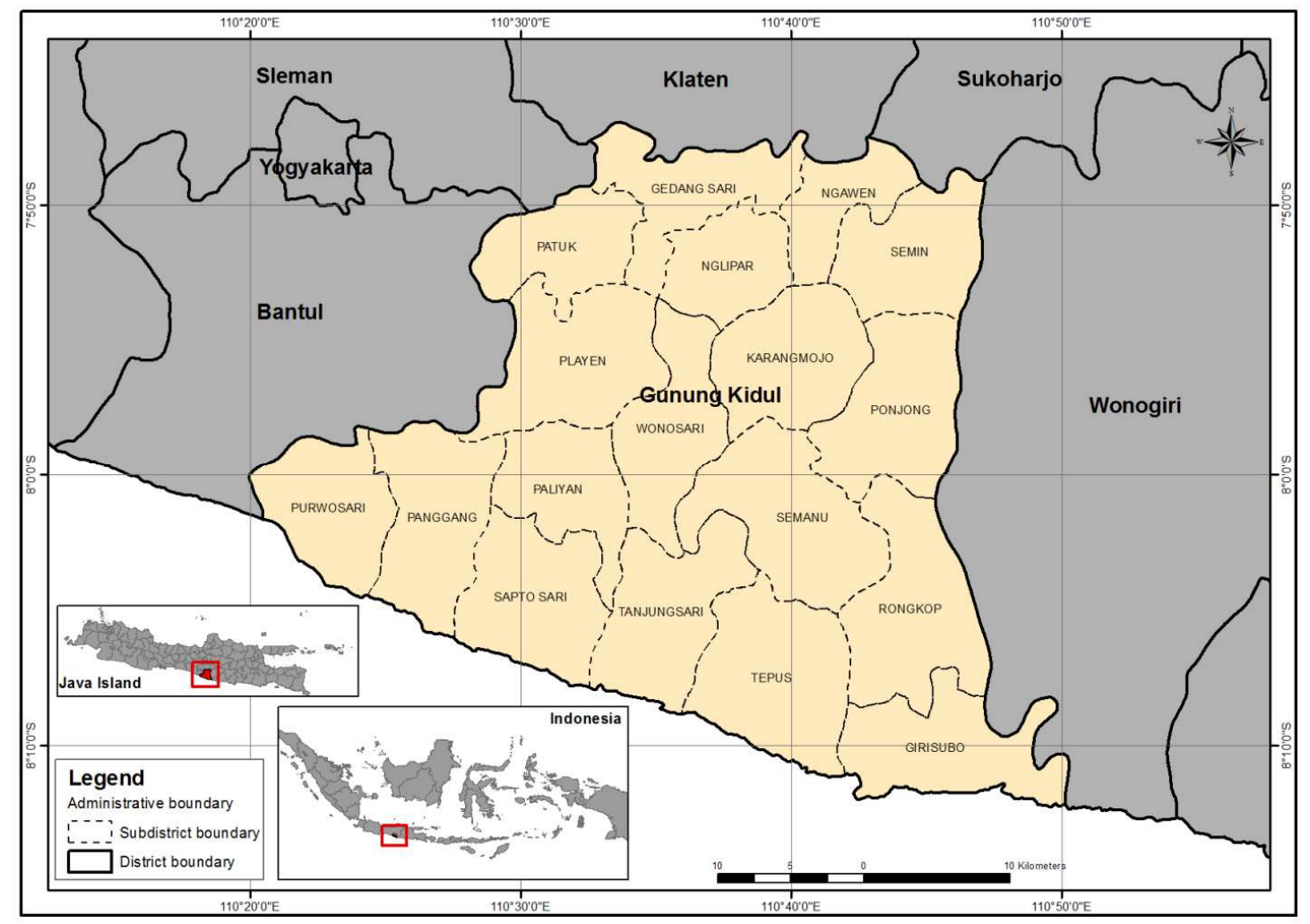

Gambar 1. Peta Kabupaten Gunungkidul, Daerah Istimewa Yogyakarta, Indonesia.

Kabupaten Gunungkidul berada di ketinggian antara 0-700 $\mathrm{m}$ dpl (meter di atas permukaan laut). Sebagian besar wilayah kabupaten ini, berada di perbukitan kapur terutama di bagian tengah dan utara. Bagian selatan Gunungkidul adalah dataran rendah yang berbatasan langsung dengan Samudera Hindia. Dalam rentang waktu tahun 2010-2013 curah hujan tertinggi di Gunungkidul terjadi pada bulan Januari (rata-rata 433,2 $\mathrm{mm}$ per bulan), dan terendah pada bulan Agustus (rata-rata 0,4 $\mathrm{mm}$ per bulan) (BPS Gunungkidul 2014).

Lahan di Gunungkidul yang diperuntukkan di bidang pertanian dan kehutanan yaitu: pertanian beririgasi 7.865 ha; pertanian tidak beririgasi 36.065 ha; pertanian berkelanjutan 5.500 ha; hutan produksi tetap 12.810 ha; hutan rakyat ${ }^{1} 38.444$ ha (Pemerintah Kabupaten Gunungkidul 2011). Hasil panen dari lahan sawah antara lain: padi, jagung, kacang tanah, kedelai, kapas. Sedangkan untuk hutan rakyat berupa kayu dan hasil hutan bukan kayu, dengan produksi pada tahun 2012-2013 seperti pada Tabel 1.

\footnotetext{
${ }^{1}$ Hutan rakyat berdasarkan Keputusan Menteri Kehutanan No. 49/Kpts.II/1997 adalah hutan yang dimiliki rakyat dengan luas minimal 0,25 ha dengan penutupan tajuk tanaman kayu-kayuan dan atau jenis lainnya lebih dari $50 \%$ dan atau pada tanaman tahun pertama dengan tanaman sebanyak 500 tanaman per hektar.
} 
Tabel 1. Produksi hasil hutan rakyat di Kabupaten Gunungkidul tahun 2012-2013

\begin{tabular}{rlcrr}
\hline \multicolumn{1}{c}{ No } & Hasil & satuan & Tahun 2012 & Tahun 2013 \\
\hline Kayu & & & & \\
\hline 1 & Kayu Jati & $\mathrm{m}^{3}$ & $55.958,5$ & $2.434,7$ \\
\hline 2 & Mahoni & $\mathrm{m}^{3}$ & $4.505,3$ & 285,2 \\
\hline 3 & Sonokeling & $\mathrm{m}^{3}$ & $4.338,2$ & 274,1 \\
\hline 4 & Akasia & $\mathrm{m}^{3}$ & $1.262,1$ & 73,8 \\
\hline Hasil Hutan & Bukan Kayu & & & 92,5 \\
\hline 5 & Madu & Liter & 241,0 & 541,9 \\
\hline 7 & Bambu & Batang & 541,9 & 7,8 \\
\hline
\end{tabular}

Sumber: BPS Kabupaten Gunungkidul, 2014

Studi ini dilakukan di dua desa yang berada di dua kecamatan di Kabupaten Gunungkidul yaitu: Desa Bejiharjo, Kecamatan Karangmojo dan Desa Karangduwet, Kecamatan Paliyan. Bejiharjo merupakan satu dari sembilan desa yang ada di Kecamatan Karangmojo. Desa ini berjarak $6 \mathrm{~km}$ dari pusat pemerintahan kabupaten yang berada di Wonosari (BPS Gunungkidul 2014). Wilayah Bejiharjo seluas 2.201 ha dengan jumlah penduduk 14.588 jiwa yang tersebar pada 20 dusun. Seperti halnya desa di Kecamatan Karangmojo lainnya, sebagian besar penduduk Desa Bejiharjo berkegiatan di sektor pertanian dan kehutanan. Dalam Rencana Tata Ruang Wilayah Kabupaten Gunungkidul 20102030 lahan yang dikelola sebagai Hutan Rakyat di Kecamatan Karangmojo seluas 1.869 ha, sedangkan Hutan Produksi Tetap seluas 946,7 ha (Pemerintah Kabupaten Gunugkidul 2011).

Desa Karangduwet masuk dalam wilayah administrasi Kecamatan Paliyan, yang berada di sebelah barat daya Wonosari. Desa ini berjarak 17,2 km dari Wonosari (BPS Gunungkidul 2014). Lahan di Kecamatan Paliyan yang diperuntukkan sebagai Hutan Rakyat seluas 1.140 ha dan Hutan Produksi Tetap seluas 2.224 ha (Pemerintah Kabupaten Gunungkidul 2011).

\subsection{Kabupaten Sumbawa, Provinsi Nusa Tenggara Barat}

Sumbawa merupakan satu dari lima kabupaten yang terletak di Pulau Sumbawa, Provinsi Nusa Tenggara Barat. Selain Sumbawa ada empat kabupaten/kota lainnya, yaitu: Kabupaten Sumbawa Barat, Kabupaten Dompu, Kabupaten Bima dan Kota Bima. Kabupaten Sumbawa memiliki luas wilayah 664.398 ha yang terdiri dari 24 kecamatan, 158 desa dan delapan kelurahan. Jumlah penduduk Kabupaten Sumbawa tahun 2012 sebanyak 419.989 jiwa yang terdiri dari 214.387 laki-laki dan 205.602 perempuan. Topografi Kabupaten Sumbawa cenderung berbukit-bukit dengan ketinggian antara 0-1.730 mdpl, dimana 41\% dari luas wilayahnya berada di ketinggian 100-500 mdpl. Jika dilihat dari penggunaan lahan, sebesar 42,\% dari luas wilayah Kabupaten Sumbawa adalah hutan negara, dan 23,9\% dipergunakan untuk sawah, kebun, ladang, perkebunan, tambak dan penggunaan 
lainnya. Secara terperinci penggunaan lahan di Kabupaten Sumbawa di sektor pertanian, perkebunan dan kehutanan sebagai berikut: sawah 51.588 ha; tegal/kebun 60.611 ha; ladang/huma 17.178 ha; perkebunan 26.496 ha. Curah hujan terbanyak di Kabupaten Sumbawa terjadi di Bulan Maret yaitu sebesar 465,5 mm per bulan (BPS Sumbawa 2013)

Kecamatan Batulanteh merupakan salah satu kecamatan di Kabupaten Sumbawa yang memiliki luas wilayah 39.140 ha, dengan jumlah penduduk 10.333 jiwa dengan jumlah laki-laki 5.399 jiwa dan perempuan 4.934 jiwa. Topografi Kecamatan Batulanteh secara umum adalah pegunungan dengan ketinggian 250-900 mdpl. Kecamatan Batulanteh berjarak 17 km dari pusat pemerintahan Kabupaten Sumbawa di Sumbawa Besar. Secara administrasi Kecamatan Batulanteh terdiri dari enam desa yaitu: Batu Rotok, Tangkal Pulit, Boa Desa, Tepal, Batudulang, Klungkung. Batudulang adalah salah satu desa yang terpilih untuk studi ini, dan berlokasi di hulu daerah aliran sungai. Desa ini cukup dekat dengan kawasan hutan lindung yang menjadi tangkapan air untuk Kabupaten Sumbawa (BPS Sumbawa 2013). Survei rumah tangga yang dilakukan Tim Kanoppi ICRAF-CIFOR (2014) menyatakan sebesar 48,6\% penduduk Desa Batudulang bekerja di lahan sendiri (pertanian), dimana lahan mereka dikelola sebagai tegalan/kebun angkum/kebun campuran. Kebun masyarakat Desa Batudulang biasanya ditanami tanaman kayu, kopi, kemiri, tanaman buah (nangka, mangga, alpukat, d1l). Selain melakukan kegiatan berkebun, sebagian penduduk Desa Batudulang juga mengumpulkan madu hutan.

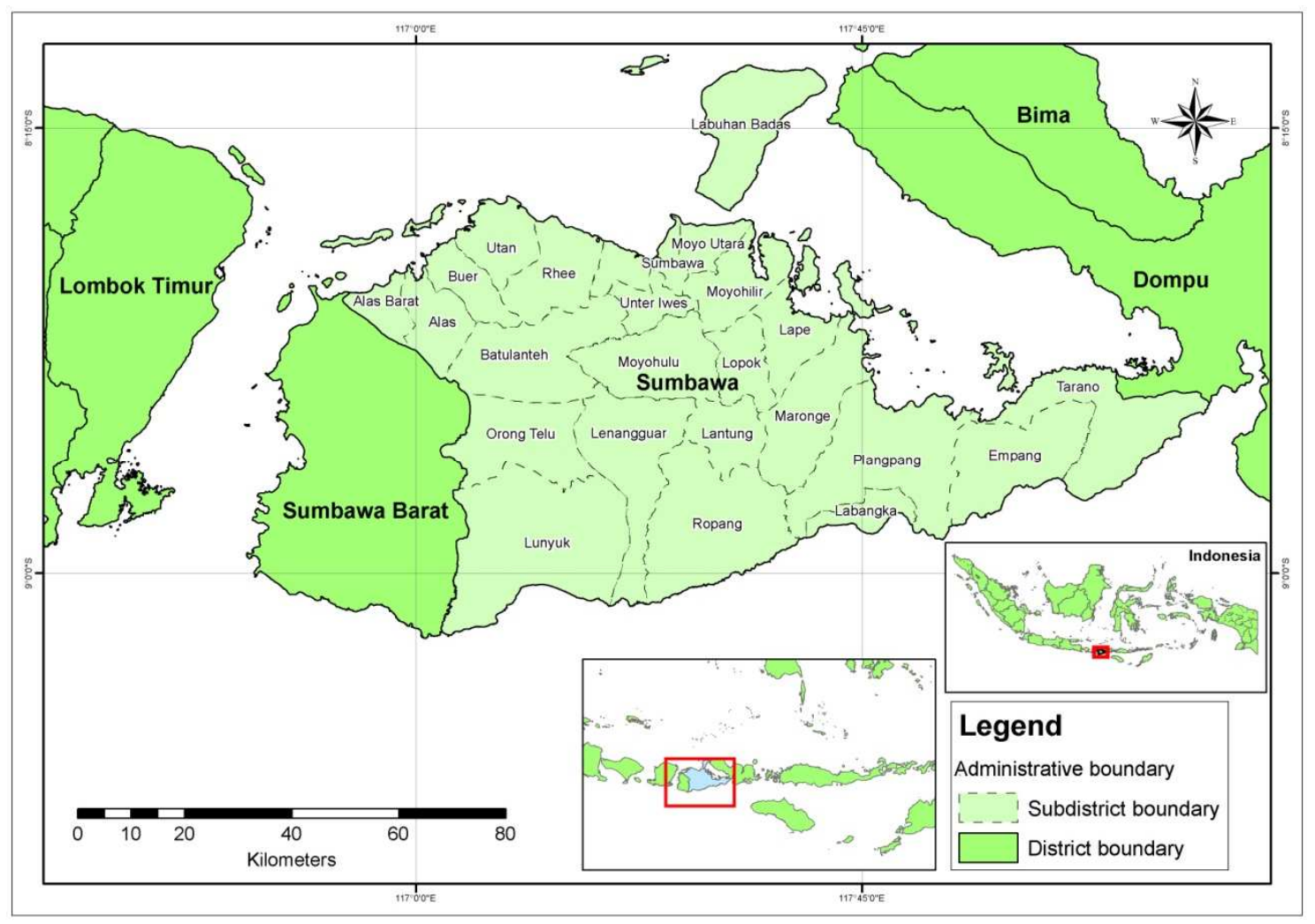

Gambar 2. Peta Kabupaten Sumbawa, Nusa Tenggara Barat, Indonesia. 
Berbeda dengan Kecamatan Batulanter yang jauh dari pusat pemerintahan Kabupaten Sumbawa, Kecamatan Unter Iwes hanya berjarak dua kilometer dengan pusat pemerintahan Kabupaten Sumbawa. Kecamatan ini memiliki luas wilayah 4.483 ha dengan jumlah penduduk pada tahun 2012 sebanyak 18.493 jiwa (9.530 laki-laki, 8.963 perempuan). Wilayah Kecamatan Unter Iwes berada pada ketinggian 21-113 mdpl. Secara admistrasi kecamatan ini dibagi dalam delapan desa yaitu: Pelat, Kerekeh, Boak, Jorok, Kerato, Uma Beringin, Pungka, dan Nijang (BPS Sumbawa 2013). Desa yang menjadi salah satu lokasi studi adalah Desa Pelat yang dapat ditempuh sekitar limabelas menit dari Kota Sumbawa Besar. Hasil survei rumah tangga tim Kanoppi (2014) menunjukkan sebagian besar penduduk Desa Pelat $(57,4 \%)$ bekerja di lahan sendiri di bidang pertanian. Mereka mengelola lahan dengan sistem tegalan/kebun campuran (37,5\%); kebun/gepang (30,9\%); sawah (27,2\%). Jenis tanaman yang sering ditemui adalah pohon penghasil kayu sebesar $21,7 \%$ dan palawija sebesar $28,3 \%$.

\subsection{Kabupaten Timor Tengah Selatan, Nusa Tenggara Timur}

Kabupaten Timor Tengah Selatan terletak di Pulau Timor dan beribukota di Kota Soe yang dapat ditempuh dalam waktu tiga jam perjalanan menggunakan mobil dari Kota Kupang. Kabupaten Timor Tengah Selatan memiliki luas wilayah 395.536 ha, dengan jumlah penduduknya 451.922 jiwa (222.490 laki-laki; 229.432 perempuan) dan 112.446 kepala keluarga. Secara administrasi, kabupaten ini terbagi dalam 32 kecamatan, 266 desa dan 12 kelurahan. Topografi Kabupaten Timor Tengah Selatan beragam mulai dari ketinggian 44-1.600 mdpl. Produk hasil kehutanan kayu, menurut data BPS Timor Tengah Selatan (2014) masih didominasi oleh kayu rimba campuran dan kayu jati (Tabel 2.). Sedangkan hasil hutan bukan kayu produksi Kabupaten Timor Tengah Selatan sebagai penghasil asam, kemiri dan madu.

Tabel 2. Produksi kayu dan hasil hutan bukan kayu di Kabupaten Timor Tengah Selatan tahun 2011-2013

\begin{tabular}{|c|c|c|c|c|c|}
\hline No & Jenis Produk & Satuan & Tahun 2011 & Tahun 2012 & Tahun 2013 \\
\hline \multicolumn{6}{|l|}{ Kayu } \\
\hline 1 & Kayu Rimba Campuran Olahan & $\mathrm{m}^{3}$ & $1.042,8$ & 822,8 & $1.547,5$ \\
\hline 2 & Kayu Jati Olahan & $\mathrm{m}^{3}$ & 346,1 & 116,4 & 486,6 \\
\hline 3 & Kayu Mahoni & $\mathrm{m}^{3}$ & 107,2 & 178,0 & 113,1 \\
\hline 4 & Kayu Merah & $\mathrm{m}^{2}$ & 25,2 & 7,2 & 31,00 \\
\hline \multicolumn{6}{|c|}{ Hasil Hutan Bukan Kayu } \\
\hline 1 & Asam & Ton & $1.693,7$ & $3.810,0$ & $39.000,0$ \\
\hline 2 & Kemiri & Ton & 537,0 & $3.014,0$ & $15.500,0$ \\
\hline
\end{tabular}

Sumber: BPS Kabupaten Timor Tengah Selatan, 2014 
Kecamatan Fatumnasi merupakan salah satu kecamatan dari tigapuluh dua kecamatan di Kabupaten Timor Tengah Selatan. Kecamatan ini berjarak 37 km dari Kota Soe. Kecamatan Fatumnasi memiliki luas wilayah 19.865 ha dengan jumlah penduduk 6.784 jiwa (3.346 laki-laki, 3.438 perempuan).

Kecamatan Fatumnasi berada di wilayah Pegunungan Mutis yang memiliki ketinggian rata-rata 1.480 mdpl. Kecamatan Fatumnasi secara administrasi terdiri dari lima desa yaitu Fatumnasi, Nenas, Naupin, Kuannoel dan Mutis. Kecamatan Fatumnasi merupakan salah satu penghasil sayuran di Kabupaten Timor Tengah Selatan. Hasil pertanian sayuran yang menjadi komoditas unggulan di Kecamatan Fatumnasi antara lain: wortel, kubis, bawang daun, kentang, bawang merah dan bawang putih. Sayuran tersebut biasanya dipasarkan ke pasar di sekitar Kecamatan Fatumnasi seperti Pasar Naupin, Pasar Kuannuel dan Pasar Kapan.

Kecamatan Mollo Utara berjarak 20,6 km dari ibukota kabupaten. Kecamatan Mollo Utara memiliki luas wilayah 20.822 ha dengan jumlah penduduk 23.917 jiwa (11.814 laki-laki, 12.103 perempuan). Kecamatan Mollo Utara berada di daerah perbukitan dengan ketinggian rata-rata $1.007 \mathrm{mdpl}$.

Kecamatan ini secara administrasi terdiri dari 18 desa, salah satunya adalah Desa Bosen yang menjadi lokasi studi.

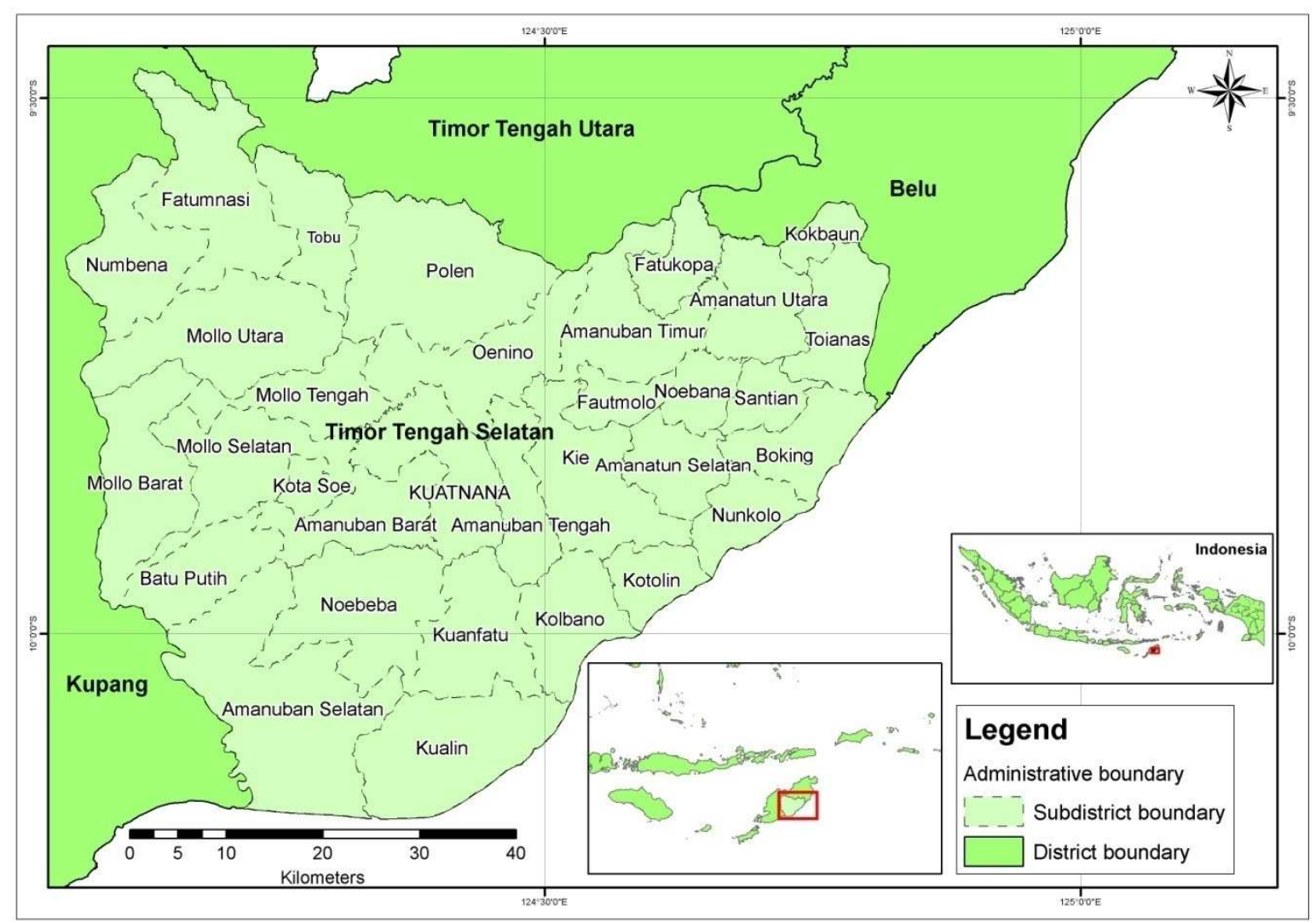

Gambar 3. Peta Kabupaten Timor Tengah Selatan, Nusa Tenggara Timur, Indonesia. 


\section{Hasil dan Pembahasan}

\subsection{Sejarah kerja penyuluhan di Indonesia}

Penyuluhan pertanian di Indonesia telah dimulai sejak tahun 1817, ketika Dr. CGL Reinwardt, mendirikan Kebun Raya Bogor dan memperkenalkan 50 jenis tanaman baru (Syufri 2011). Sejak itu sistem kerja penyuluhan di Indonesia terus berkembang dan berubah. Sejarah perkembangan kerja penyuluhan di Indonesia tidak bisa lepas dari kondisi politik dan pemerintahan di setiap periodenya (Tabel 3.). Pendekatan dan metode kerja penyuluhan mengalami perubahan yang cukup dinamis mulai dari pendekatan perorangan; pendekatan massal; pendekatan kelompok; pendekatan antar kelompok; hingga pendekatan partisipatif. Sistem penyuluhan pertanian, perikanan dan kehutanan di Indonesia saat ini diatur dalam Undang-Undang Republik Indonesia Nomor 16 Tahun 2006. Sebelum diterbitkannya UU No. 16/2006, penyuluhan dilakukan masing-masing sektoral dimana penyuluhan pertanian dilakukan oleh Dinas Pertanian, penyuluhan perikanan dilakukan Dinas Perikanan dan penyuluhan kehutanan dilakukan oleh Dinas Kehutanan.

Tabel 3. Sejarah penyuluhan pertanian di Indonesia dari tahun 1900 hingga sekarang (2016).

\begin{tabular}{|c|c|c|}
\hline Periode waktu & Gambaran Kerja Penyuluhan & Strategi Pendekatan yang digunakan \\
\hline $\begin{array}{l}\text { Pemerintahan } \\
\text { Kolonial } \\
\text { Belanda (1905- } \\
\text { 1942) }\end{array}$ & $\begin{array}{l}\text { Pada periode ini mulai di bentuk Departemen } \\
\text { Pertanian (Landbouw Nijverheid en Handel) } \\
\text { dan Dinas Penyuluhan Pertanian (Landbouw } \\
\text { Voorlichtings Dienst-LDV). Penyuluhan } \\
\text { dilakukan untuk melakukan modernisasi } \\
\text { usahatani berdasarkan hasil penelitian } \\
\text { meliputi: pengolahan tanah, pengairan, } \\
\text { pemupukan (hijau, kompos dan an-organik), } \\
\text { pemakaian benih unggul, dan } \\
\text { pemberantasan hama penyakit. }\end{array}$ & $\begin{array}{l}\text { - Pada tahun } 1905 \text { penyuluhan dilakukan } \\
\text { atas dasar perintah kepada petani. } \\
\text { - Mulai tahun } 1908 \text { mulai dirintis } \\
\text { pendekatan penyuluhan atas dasar } \\
\text { pendidikan dan kesukarelaan. } \\
\text { - Pendidikan pertanian formal dengan } \\
\text { membuka sekolah pertanian dan } \\
\text { pendidikan non formal dengan kursus } \\
\text { tani. } \\
\text { - Strategi penyuluhan dengan pendekatan } \\
\text { perorangan yang sering dikenal dengan } \\
\text { pendekatan "tetesan minyak" (olievlek- } \\
\text { sijsteem). }\end{array}$ \\
\hline $\begin{array}{l}\text { Pemerintahan } \\
\text { Jepang (1942- } \\
\text { 1945) }\end{array}$ & $\begin{array}{l}\text { Penyuluhan pada periode ini tidak berjalan } \\
\text { karena petani dipaksa untuk menghasilkan } \\
\text { bahan makanan dan bahan strategis lainnya. }\end{array}$ & \\
\hline 1945-1950 & $\begin{array}{l}\text { Rencana produksi pertanian tiga tahun dalam } \\
\text { Rencana Kasimo }{ }^{2} \text { tidak terlaksana karena } \\
\text { adanya revolusi fisik (perang paska } \\
\text { kemerdekaan). }\end{array}$ & \\
\hline
\end{tabular}

\footnotetext{
${ }^{2}$ Merupakan rencana produksi pertanian selama tiga tahun (1948-1950) yang digagas oleh menteri persediaan makanan rakyat pada saat itu I.J Kasimo. Rencana Kasimo berfokus pada: (i) penanaman lahan kosong di Sumatera Timur; (ii) melakukan intensifikasi di pulau Jawa dengan memeperbanyak penanaman bibit unggul; (iii) pencegahan penyembelihan ternak produktif; (iv) pembentukan kebun bibit di setiap desa; (v) Transmigrasi bagi 20 juta penduduk pulau Jawa ke Pulau Sumatera dalam waktu 10-20 tahun.
} 


\begin{tabular}{|c|c|c|}
\hline Periode waktu & Gambaran Kerja Penyuluhan & Strategi Pendekatan yang digunakan \\
\hline $1950-1959$ & $\begin{array}{l}\text { Rencana Kasimo yang belum terlaksana di } \\
\text { gabung dengan Rencana Wisaksono } \\
\text { menjadi Rencana Kesejahteraan Istimewa } \\
\text { (RKI). Pada periode ini didirikan Balai } \\
\text { Pendidikan Masyarakat Desa di setiap } \\
\text { kecamatan guna mendukung pelaksanaan } \\
\text { RKI. }\end{array}$ & $\begin{array}{l}\text { Pendekatan perorangan/ pendekatan } \\
\text { "tetesan minyak". }\end{array}$ \\
\hline $1960-1963$ & $\begin{array}{l}\text { Perubahan politik mempengaruhi target } \\
\text { produksi pertanian pada periode ini. Pada } \\
\text { pemerintahan demokrasi terpimpin, RKI } \\
\text { diganti dengan Pola Pembangunan Nasional } \\
\text { Semesta Berencana (PNSB) dimana salah } \\
\text { satu programnya adalah swasembada beras } \\
\text { dari tingkat nasional sampai pedesaan dalam } \\
\text { satu Komando Operasi Gerakan Makmur. }\end{array}$ & $\begin{array}{l}\text { Pendekatan massal, kampanye besar- } \\
\text { besaran dalam sistem komando. }\end{array}$ \\
\hline $1963-1974$ & $\begin{array}{l}\text { Di akhir masa demokrasi terpimpin dan } \\
\text { kegagalan swasembada beras, timbul } \\
\text { rencana mengembalikan kembali } \\
\text { penyuluhan ke azas semula yaitu: } \\
\text { kesukarelaan, pendidikan dan demokrasi. } \\
\text { - Perubahan politik dan masyarakat yang } \\
\text { menuju era pembangunan mentargetkan } \\
\text { swasembada beras dengan pola } \\
\text { intensifikasi khusus (Insus) padi. Dalam } \\
\text { pola Insus ini pemerintah menargetkan 2- } \\
3 \text { kali panen padi dalam satu hamparan } \\
\text { lahan yang sudah diberi fasilitasi irigrasi. }\end{array}$ & $\begin{array}{l}\text { - Demonstrasi Massal, Bimbingan Massal } \\
\text { dan Intensifikasi Massal. } \\
\text { - Pendekatan dilakukan melalui kelompok } \\
\text { tani. Pada pendekatan ini mulai di kenal } \\
\text { kontaktani yaitu petani unggulan yang } \\
\text { menjadi sukarelawan dalam melakukan } \\
\text { penyuluhan. } \\
\text { - Metode massal seperti siaran radio, } \\
\text { pertunjukan, pameran, kesenian } \\
\text { tradisional digunakan dalam periode ini. }\end{array}$ \\
\hline $1974-1983$ & $\begin{array}{l}\text { Pada periode ini dibentuk Badan Pendidikan } \\
\text { Pelatihan dan Penyuluhan yang berwenang } \\
\text { mengatur pendidikan pelatihan dan } \\
\text { penyuluhan di tingkat nasional. Pada tahun } \\
1976 \text { diterapkan sisten kerja latihan dan } \\
\text { kunjungan (LAKU). Sistem kerja penyuluh } \\
\text { diatur dalam sistem Penyuluhan Pertanian } \\
\text { Lapangan (PPL) di wilayah unit kerja desa. }\end{array}$ & $\begin{array}{l}\text { Penyuluhan dengan sistem kerja latihan dan } \\
\text { kunjungan dilakukan dengan pendekatan } \\
\text { pada kelompok tani dalam wilayah unit desa. }\end{array}$ \\
\hline $1983-1993$ & $\begin{array}{l}\text { Pada periode ini diterapkan pola Supra } \\
\text { Intensifikasi Khusus yang dikenal dengan } \\
\text { Supra Insus. Supra Insus sendiri } \\
\text { mengharuskan petani menggunakan hormon } \\
\text { pertumbuhan untuk mempercepat produksi. }\end{array}$ & $\begin{array}{l}\text { Pola Supra Insus dilakukan dengan } \\
\text { pendekatan kelompok tani dan } \\
\text { pendekatan antar kelompok tani dalam } \\
\text { satu wilayah kerja penyuluhan. Pada } \\
\text { periode ini diinisiasi Kontak Tani Nelayan } \\
\text { Andalan. Metode yang digunakan pada } \\
\text { pendekatan antar kelompok tani seperti: } \\
\text { mimbar bersama, temu teknologi, temu } \\
\text { wicara, temu karya. } \\
\text { Di tingkat nasional adanya Pekan } \\
\text { Penyuluhan Nasional. Sistem kerja } \\
\text { latihan dan kunjungan mulai dievaluasi }\end{array}$ \\
\hline
\end{tabular}

${ }^{3}$ Wiksaksono Wirodhiharjo (Walikota Bogor), pada tahun 1951 oleh Wakil Presiden Moh Hatta dianggkat menjadi Kepala Balai Perguruan Tinggi Rebuplik Indonesia yang mengurusi bidang pertanian dan perikanan untuk wilayah negara-negara bagian/federal yang dibina oleh Belanda. Dalam melaksanakan tugasnya beliau menyusun rencana kerja yang di kenal dengan Rencana Wiksaksono. 


\begin{tabular}{|c|c|c|}
\hline Periode waktu & Gambaran Kerja Penyuluhan & Strategi Pendekatan yang digunakan \\
\hline & & $\begin{array}{l}\text { dan di modifikasi dengan pendekatan } \\
\text { yang lebih holistik, yaitu: pertanian, } \\
\text { industri kecil, kesehatan, pendidikan, } \\
\text { perkoperasian. }\end{array}$ \\
\hline $1993-1997$ & $\begin{array}{l}\text { Periode ini orientasi pembangunan pertanian } \\
\text { di Indonesia mulai mengarah ke pendekatan } \\
\text { agrobisnis, sehingga kegiatan penyuluhan } \\
\text { juga mulai berubah. Partisipasi dan } \\
\text { kemandirian petani dan kelompok menjadi } \\
\text { sasaran dalam program penyuluhan. }\end{array}$ & $\begin{array}{l}\text { Pendekatan partisipatif dan cost sharing } \\
\text { mulai digunakan pada periode ini. Pelatihan } \\
\text { petani mulai menerapkan metode andragogic } \\
\text { (pendidikan orang dewasa) seperti: sekolah } \\
\text { lapang usahatani agrobisnis, sekolah lapang } \\
\text { pengendalian hama terpadu. }\end{array}$ \\
\hline $1998-2006$ & $\begin{array}{l}\text { Pada periode ini kegiatan penyuluhan } \\
\text { diserahkan ke pemerintah Kabupaten/Kota } \\
\text { sebagai bentuk dari otonomi daerah. Dengan } \\
\text { adanya otonomi daerah penyuluhan dan } \\
\text { lembaganya tergantung pada kepala daerah } \\
\text { masing-masing. }\end{array}$ & $\begin{array}{l}\text { Pendekatan yang digunakan masih } \\
\text { mengikuti periode-periode sebelumnya atau } \\
\text { disesuaikan dengan kebutuhan daerah. }\end{array}$ \\
\hline $\begin{array}{l}\text { 2006-sekarang } \\
(2016)\end{array}$ & $\begin{array}{l}\text { Diterbitkan UU Nomor } 6 \text { Tahun } 2006 \text { tentang } \\
\text { Sistem Penyuluhan Pertanian, Perikanan dan } \\
\text { Kehutanan di Indonesia. }\end{array}$ & $\begin{array}{l}\text { Pendekatan dengan program } 1 \text { penyuluh } 1 \\
\text { desa. }\end{array}$ \\
\hline
\end{tabular}

Sumber: Ahmad, 2011.

Kerja penyuluhan di Indonesia sebelum diterbitkan UU No. 16/2006 lebih banyak pada sektor produksi tanaman pangan terutama padi dibandingkan pada budidaya kehutanan maupun perikanan. Hal tersebut dipengaruhi oleh prioritas pembangunan pertanian di Indonesia dalam bidang pertanian, yaitu swasembada beras. Pendekatan dan metode yang digunakan dalam penyuluhan tanaman pangan memiliki karakter yang berbeda dengan penyuluhan kehutanan dan agroforestri. Hal tersebut dipengaruhi oleh tipe tanaman dan keragaman tanaman yang berbeda. Penyuluhan tanaman pangan pada era yang lalu relatif hanya satu jenis tanaman (monokultur) dengan waktu budidaya yang pendek. Budidaya tanaman kehutanan (kayu) relatif membutuhkan waktu yang panjang dan tenaga yang lebih banyak karena adanya teknik pemangkasan ranting maupun penjarangan pohon guna hasil yang baik secara kuantitas dan kualitas. Pada pengelolaan agroforestri cenderung memiliki komoditi tanaman yang lebih dari satu jenis yang ditumpangsarikan antara tanaman kehutanan, tanaman perkebunan dan tanaman pangan.

Masih sedikitnya praktik penyuluhan kehutanan dan agroforestri dibanding dengan penyuluhan pertanian menjadi tantangan dalam mengembangkan produksi dan pemasaran produk kehutanan dan agroforestri. Pendekatan dan metode yang pernah digunakan dalam penyuluhan pertanian di Indonesia dapat dijadikan salah satu rujukan dalam mengembangkan penyuluhan kehutanan dan agroforestri di Indonesia. 


\subsection{Kelembagaan Penyuluhan}

Sejak diterbitkannya UU No. 16/2006 pelaksanaan penyuluhan pertanian, perikanan dan kehutanan di Indonesia dilakukan oleh kelembagaan penyuluhan yang dibentuk dari tingkat pusat sampai dengan kecamatan. Kegiatan penyuluhan yang dahulunya berada di bawah masing-masing kementerian dan dinas di daerah sekarang dikoordinasi dan bekerja di bawah naungan kelembagaan penyuluhan yang berupa Badan Penyuluhan. Koordinasi lintas sektoral dan peran penyuluh yang polivalen menjadi tantangan pelaksanaan penyuluhan dari diterbitkannya UU No. 16/2006.

Perubahan kelembagaan penyuluhan memerlukan waktu untuk bisa dilaksanakan sepenuhnya di tingkat pemerintah daerah. Banyak kabupaten/kota yang baru membentuk Badan Pelaksana Penyuluhan pada tahun kelima setelah undang-undang disahkan. Penamaan Badan Pelaksanaan di tingkat kabupaten masih berbeda-beda, ada yang bernama Badan Pelaksana Penyuluhan dan Ketahanan Pangan (BP2KP), Badan Ketahanan Pangan dan Penyuluhan (BKP2), ataupun Badan Pelaksana Penyuluhan Pertanian, Perikanan dan Kehutanan (BP4K). Ketidakseragaman tersebut disesuaikan dengan kebutuhan dan kondisi masing-masing daerah. Pada tahun 2014 terbit Peraturan Presiden (Perpres) No. 154 tentang kelembagaan penyuluhan yang mengatur tentang kelembagaan penyuluhan dari tingkat pusat sampai dengan tingkat kecamatan. Dalam Perpres ini dijelaskan dan diatur fungsi dan tugas setiap kelembagaan penyuluhan dan tata kerja dari lembaga penyuluhan.

Menurut Perpres No. 154/2014 kelembagaan penyuluhan pemerintah sebagai berikut:

- Kelembagaan penyuluhan pada tingkat pusat yaitu: Badan Penyuluhan dan Pengembangan Sumber Daya Manusia (BP2SDM) di Kementerian Pertanian; Badan Pengembangan Sumber Daya Manusia (BPSDM) di Kementerian Perikanan dan Kelautan; dan Badan Penyuluhan dan Pengembangan Sumber Daya Manusia (BP2SDM) di Kementerian Lingkungan Hidup dan Kehutanan. Bertanggung jawab kepada menteri dan dipimpin oleh Kepala Badan.

- Kelembagaan penyuluhan pada tingkat provinsi yaitu: Badan Koordinasi Penyuluhan (Bakorluh) dimana bertanggung jawab kepada presiden melalui menteri. Bakorluh diketuai oleh gubernur.

- Kelembagaan penyuluhan di tingkat kabupaten/kota yaitu: Badan Pelaksana Penyuluhan Pertanian, Perikanan dan Kehutanan (BP4K) bertanggung jawab kepada Bupati atau Walikota dan dipimpin oleh kepala setingkat ekselon II b.

- Kelembagaan penyuluhan di tingkat kecamatan yaitu: Balai Penyuluhan Pertanian, Perikanan dan Kehutanan (BP3K) yang bertanggung jawab kepada Kepala BP4K. 
Kementerian Pertanian; Kementerian Kelautan dan Perikanan; Kementerian Lingkungan Hidup dan Kehutanan

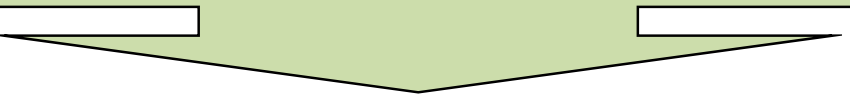

Badan Penyuluhan dan Pengembangan Sumber Daya Manusia Kementerian Pertanian;

Badan Pengembangan Sumber Daya Manusia Kementerian Kelautan dan Perikanan;

Badan Penyuluhan dan Pengembangan Sumber Daya Manusia Kementerian Lingkungan Hidup dan Kehutanan (Tingkat Nasional)

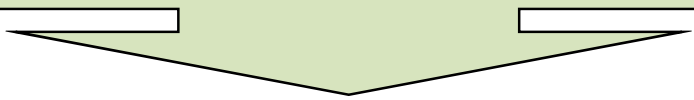

Badan Koordinasi Penvuluhan (Tinakat Provinsi)

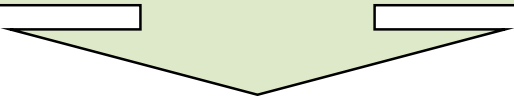

Badan Pelaksana Penyuluhan Pertanian, Perikanan dan Kehutanan (Tingkat Kabupaten Kota)

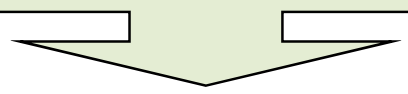

Balai Penyuluhan Pertanian, Perikanan dan Kehutanan (Tingkat Kecamatan)

Gambar 4. Diagram kelembagaan penyuluhan pemerintah di Indonesia berdasarkan Peraturan Presiden No. $154 / 2014$ tentang kelembagaan penyuluhan.

\subsubsection{Kelembagaan Penyuluhan Pemerintah Pada Tingkat Kabupaten}

Kelembagaan penyuluhan di ketiga lokasi studi ini memiliki karakter yang berbeda baik dari penamaan, struktur organisasi dan program penyuluhannya (Tabel 4.).

Tabel 4. Kelembagaan Penyuluhan di Kabupaten Gunungkidul, Kabupaten Sumbawa dan Kabupaten Timor Tengah Selatan.

\begin{tabular}{|c|c|c|c|}
\hline Item & Kabupaten Gunungkidul & Kabupaten Sumbawa & $\begin{array}{l}\text { Kabupaten Timor Tengah } \\
\text { Selatan }\end{array}$ \\
\hline $\begin{array}{l}\text { Nama } \\
\text { Kelembagaan } \\
\text { Penyuluhan } \\
\text { Kabupaten }\end{array}$ & $\begin{array}{l}\text { Badan Pelaksana } \\
\text { Penyuluhan dan Ketahanan } \\
\text { Pangan (BP2KP). }\end{array}$ & $\begin{array}{l}\text { Badan Pelaksana } \\
\text { Penyuluhan Pertanian, } \\
\text { Perikanan dan Kehutanan } \\
\text { (BP4K). }\end{array}$ & $\begin{array}{l}\text { Badan Ketahanan Pangan } \\
\text { dan Penyuluhan (BKP2). }\end{array}$ \\
\hline Tahun dibentuk & 2008 (Perda No. 12/2008) & 2010 (Perda No. 3/2010) & 2012 \\
\hline Tugas & $\begin{array}{l}\text { Melaksanakan urusan } \\
\text { pemerintahan daerah dan } \\
\text { tugas perbantuan di bidang } \\
\text { penyuluhan pertanian, } \\
\text { perikanan dan kehutanan } \\
\text { serta ketahanan pangan. }\end{array}$ & $\begin{array}{l}\text { Melaksanakan penyusunan } \\
\text { dan pelaksanaan kebijakan } \\
\text { daerah di bidang } \\
\text { penyuluhan pertanian, } \\
\text { perikanan dan kehutanan. }\end{array}$ & $\begin{array}{l}\text { Melaksanakan urusan } \\
\text { pemerintah daerah di bidang } \\
\text { ketahan pangan, } \\
\text { penyuluhan pertanian, } \\
\text { perikanan dan kehutanan. }\end{array}$ \\
\hline
\end{tabular}




\begin{tabular}{|c|c|c|c|}
\hline Item & Kabupaten Gunungkidul & Kabupaten Sumbawa & $\begin{array}{l}\text { Kabupaten Timor Tengah } \\
\text { Selatan }\end{array}$ \\
\hline $\begin{array}{l}\text { Bidang yang } \\
\text { ada }\end{array}$ & $\begin{array}{l}\text { - Bidang Kelembagaan } \\
\text { dan Ketenagaan; } \\
\text { - Bidang Program, Sarana } \\
\text { dan Prasarana; } \\
\text { - Bidang Ketahanan } \\
\text { Pangan. }\end{array}$ & $\begin{array}{l}\text { - Bidang Pembinaan } \\
\text { Kelembagaan; } \\
\text { - Bidang Sumberdaya } \\
\text { Manusia dan } \\
\text { Penyelenggaraan } \\
\text { Penyuluhan; } \\
\text { - Bidang Sarana, } \\
\text { Prasarana dan } \\
\text { Kerjasama } \\
\text { Penyuluhan. }\end{array}$ & $\begin{array}{l}\text { - Bidang Penyuluhan } \\
\text { Pertanian, Peternakan } \\
\text { dan Perkebunan; } \\
\text { - Bidang Penyuluhan } \\
\text { Perikanan dan } \\
\text { Kehutanan; } \\
\text { - Bidang Ketersediaan, } \\
\text { Keamanan, Kerawanan } \\
\text { dan Konsumsi Pangan. }\end{array}$ \\
\hline
\end{tabular}

Sumber: Hasil studi berdasarkan FGD dengan penyuluh, 2015

Di Kabupaten Gunungkidul dan Kabupaten Timor Tengah Selatan, Badan Pelaksana Penyuluhan masih menjadi satu dengan ketahanan pangan, sehingga selain memiliki tugas dalam pelaksanaan penyuluhan pertanian, perikanan dan kehutanan juga memiliki tugas dalam bidang ketahanan pangan. Di Kabupaten Sumbawa, Badan Pelaksana Penyuluhan sudah spesifik bertugas untuk bidang penyuluhan pertanian, perikanan dan kehutanan. Pembentukan badan pelaksana penyuluhan tersebut diatur dengan peraturan di daerah masing-masing. Jika melihat dari tahun dibentuknya badan pelaksana penyuluhan di ketiga Kabupaten (2008, 2010, 2012), landasan hukum yang digunakan adalah UU No. 16/2006. Sedangkan Peraturan Presiden yang mengatur tentang Kelembagaan Penyuluhan Pertanian, Perikanan dan Kehutanan baru diterbitkan pada tahun 2014 yaitu Perpres No. 154. Dalam Perpres No. 154/2014 sebenarnya tidak disebutkan secara spesifik tentang penamaan badan pelaksana penyuluhan di tingkat kabupaten/kota. Pasal 12 Perpres No. 154/2014 berbunyi, "Kelembagaan penyuluhan di tingkat kabupaten/kota berbentuk badan pelaksana penyuluhan". Pada pasal 15 dijelaskan juga bahwa pembentukan badan pelaksana penyuluhan diatur melalui peraturan daerah. Pembentukan badan juga berdasarkan kriteria potensi wilayah bidang pembangunan pertanian, perikanan, atau kehutanan.

Jika dilihat dari tahun pembentukan Badan Pelaksanaan Penyuluhan di masing-masing kabupaten bahwa implementasi UU No. 16/2006 relatif lebih dahulu di kabupaten yang berada di wilayah Pulau Jawa dibanding di wilayah kepulauan Nusa Tenggara. Di Kabupaten Timor Tengah Selatan, pembentukan Badan Ketahan Pangan dan Penyuluhan pada tahun 2012, hal tersebut menunjukkan bahwa implementasi undang-undang tersebut setelah enam tahun ditetapkan. Akses informasi, intensitas sosialisasi UU No. 16/2006, dan kesiapan sarana prasarana daerah mempengaruhi implementasi dari undang-undang tersebut.

\subsubsection{Kelembagaan Penyuluhan Pemerintah Pada Tingkat Kecamatan}

Kelembagaan penyuluhan pada tingkat kecamatan di Kabupaten Gunungkidul bernama Balai Penyuluhan Pertanian, Perikanan dan Kehutanan (BP3K). BP3K dikoordinasi oleh seorang 
koordinator penyuluh, dibantu seorang supervisor penyuluh. Selain tenaga penyuluh BP3K ada satu orang mantri tani dan satu orang pengamat organisme pengganggu tanaman. Kabupaten Gunungkidul memiliki 18 BP3K yang ada di masing-masing kecamatan. BP3K Kecamatan Paliyan dan Kecamatan Karangmojo yang menjadi sampel studi memiliki struktur organisasi yang sama. Menurut Wagimin, S.ST (laki-laki, 58 th), koordinator penyuluh BP3K Kecamatan Karangmojo, bahwa tugas dan fungsi lembaga BP3K adalah: 1) Melaksanakan penyuluhan pertanian-tanaman pangan, perkebunan dan peternakan-kepada petani; 2) Melaksanakan penyuluhan perikanan kepada petani; 3) Melaksanakan penyuluhan kehutanan kepada petani; 4) Melakukan pendampingan kepada kelompok tani; dan 5) Sebagai pusat koordinasi tenaga penyuluh di kecamatan. Dalam menjalankan tugasnya BP3K bertanggungjawab kepada Kepala Badan Pelaksana Penyuluhan dan Ketahanan Pangan (BP2KP) Kabupaten Gunungkidul.

Sedangkan untuk Kabupaten Sumbawa, dalam melaksanakan tugasnya di tingkat kecamatan, BP4K Kabupaten Sumbawa memiliki Unit Pelaksana Teknis yaitu Balai Penyuluhan Pertanian, Perikanan dan Kehutanan (BP3K). BP3K dipimpin oleh seorang koordinator balai yang secara struktural bertanggungjawab kepada Kepala BP4K Kabupaten Sumbawa. Di Kabupaten Sumbawa terdapat 18 BP3K, dengan jumlah kecamatan sebanyak 24 kecamatan. Jadi ada BP3K yang memiliki wilayah kerja di dua kecamatan. BP3K Unter Iwes adalah salah satu BP3K yang wilayah kerjanya meliputi dua kecamatan yaitu Kecamatan Unter Iwes dan Kecamatan Batu Lanteh, di Kabupaten Sumbawa. BP3K Unter Iwes beralamat di Jalan Raya Semongkat, Sering Unter Iwes, Kabupaten Sumbawa. Desa Pelat dan Desa Batudulang yang menjadi lokasi studi secara administrasi berada di wilayah kerja BP3K Unter Iwes.

Kelembagaan penyuluhan pada tingkat kecamatan di Kabupaten Timor Tengah Selatan bernama Balai Penyuluhan Kecamatan (BPK). BPK dipimpin oleh seorang kepala balai yang salah satu tugasnya mengkoordinasi tenaga penyuluh yang ada di kecamatan. Kabupaten Timor Tengah Selatan memiliki 32 BPK yang ada di setiap kecamatan. Menurut Baltasar Dara, S.ST (laki-laki, 53 th), kepala BPK Mollo Utara, BPK memiliki tugas pokok dan fungsi sebagai berikut: 1) Pelaksana penyuluhan pertanian, peternakan, perikanan dan kehutanan; 2) Penyusunan programa penyuluhan kecamatan; dan 3) Identifikasi potensi wilayah. Berdasarkan pada Surat Keputusan Bupati Timor Tengah Selatan Nomor: BKD.820/107/3/2012 tentang Penempatan Penyuluh Pada Wilayah Kerja di Kabupaten Timor Tengah Selatan, tenaga penyuluh selain memiliki fungsi sebagai penyuluh mereka juga memiliki tugas sebagai tenaga struktural di masing-masing BPK.

Kelembagaan penyuluhan pada tingkat kecamatan di Kabupaten Gunungkidul dan Sumbawa menggunakan nama Balai Penyuluhan Pertanian, Perikanan dan Kehutanan (BP3K), sedangkan di Kabupaten Timor Tengah Selatan menggunakan nama Balai Penyuluhan Kecamatan (BPK). Berdasarkan Perpres No. 154/2014 pasal 17, Kelembagaan Penyuluhan pada tingkat kecamatan 
berbentuk Balai Penyuluhan, Pertanian, Perikanan dan Kehutanan yang bertanggung jawab kepada Kepala Badan Pelaksana Penyuluhan di tingkat Kabupaten/Kota.

Dari hasil studi hanya Kabupaten Sumbawa yang belum memiliki BP3K di setiap kecamatan. Kabupaten Sumbawa memiliki 6 BP3K yang wilayah kerjanya di dua kecamatan. Sedangkan di Kabupaten Gunungkidul dan Kabupaten Timor Tengah Selatan, BP3K/BPK ada di setiap kecamatan. Secara jangkauan, layanan BP3K yang ada di setiap kecamatan lebih mudah diakses oleh petani dibandingkan dengan BP3K yang wilayah kerjanya meliputi dua kecamatan. Seperti BP3K Unter Iwes yang memiliki wilayah kerja dua kecamatan yaitu Unter Iwes dan Batulanteh, jarak yang jauh ke Desa Batudulang di Kecamatan Batulanteh menjadikan penyuluh jarang berkunjung ke desa dan sebaliknya, petani jarang berkunjung ke BP3K. Menurut Perpres No. 154/2014, BP3K berfungsi sebagai tempat pertemuan penyuluh, pelaku utama dan pelaku usaha. Berfungsinya BP3K sebagai tempat bertemunya penyuluh dan petani untuk melakukan kegiatan penyuluhan dipengaruhi oleh jarak, kemudahan transportasi (jalan dan kendaraan), dan sarana- prasarana BP3K, sebagai contoh kondisi gedung BP3K di Kabupaten Timor Tengah Selatan masih kurang memadai jika dibandingkan dengan gedung BP3K di Kabupaten Sumbawa dan Kabupaten Gunungkidul.

\subsubsection{Kelembagaan Penyuluhan Swasta}

Selain kelembagaan penyuluhan pemerintah di ketiga lokasi studi juga terdapat kelembagaan penyuluhan swasta. Kelembagaan penyuluhan swasta yang diidentifikasi adalah perusahaan dan atau lembaga yang melakukan kegiatan penyuluhan dan pendampingan kepada petani. Lembaga penyuluhan swasta yang teridentifikasi di ketiga lokasi studi disajikan pada Tabel 5. Lembaga penyuluhan swasta dalam melakukan kegiatan lebih dapat menjangkau daerah yang relatif terpencil. Program penyuluhan dan pendampingan yang dilakukan oleh lembaga penyuluhan swasta lebih mendalam dengan intensitas penyuluhan yang lebih sering dibandingkan dengan penyuluhan pemerintah. Sayangnya koordinasi antara lembaga penyuluhan swasta dengan lembaga penyuluhan pemerintah belum berjalan dengan baik. Koordinasi dan kerjasama antar lembaga penyuluhan tersebut jika berjalan dengan baik kemungkinan dapat menjadikan penyuluhan berjalan lebih efektif. 
Tabel 5. Kelembagaan Penyuluhan Swasta di Kabupaten Gunungkidul, Kabupaten Sumbawa dan Kabupaten Timor Tengah Selatan.

\begin{tabular}{|c|c|c|c|}
\hline Kelembagaan Penyuluh & Kabupaten Gunungkidul & Kabupaten Sumbawa & $\begin{array}{l}\text { Kabupaten Timor Tengah } \\
\text { Selatan }\end{array}$ \\
\hline $\begin{array}{l}\text { Kelembagaan Penyuluh } \\
\text { Swasta }\end{array}$ & $\begin{array}{l}\text { - PT Rimba Partikel } \\
\text { Indonesia } \\
\text { - PT Dipantara } \\
\text { Yogyakarta } \\
\text { - Perkumpulan ARuPA } \\
\text { - Perhimpunan Shorea } \\
\text { - Lembaga Javlec }\end{array}$ & $\begin{array}{l}\text { - UD Makassar Utama } \\
\text { - WWF - Indonesia } \\
\text { - Jaringan Madu Hutan } \\
\text { Sumbawa (JMHS) }\end{array}$ & $\begin{array}{l}\text { - } \text { Yayasan Mitra Tani } \\
\text { - Helen Keller } \\
\text { International- } \\
\text { Indonesia } \\
\text { - Sanggar Suara } \\
\text { Perempuan Soe } \\
\text { - Threads of Life } \\
\text { - } \text { WWF - Indonesia }\end{array}$ \\
\hline
\end{tabular}

Sumber: Hasil studi berdasarkan FGD dengan petani dan wawancara mendalam dengan lembaga penyuluhan swasta/ swadaya.

\subsection{Penyuluh}

Penyuluh adalah individu yang melakukan kegiatan penyuluhan. Berdasarkan UU No. 16/2006, penyuluh terdiri dari penyuluh pemerintah, penyuluh swadaya dan penyuluh swasta. Penyuluh pemerintah secara status kepegawaian terdiri dari penyuluh Pegawai Negeri Sipil (PNS) dan penyuluh Tenaga Harian Lepas (THL).

\subsubsection{Penyuluh Pegawai Negeri Sipil (PNS)}

Penyuluh PNS adalah penyuluh yang secara status kepegawaian sebagai pegawai negeri sipil. Penempatan penyuluh pada wilayah kerjanya di masing-masing kabupaten ditetapkan melalui Surat Keputusan Bupati. Pernah ada wacana bahwa penyuluh akan bertugas secara polivalen, yaitu penyuluh akan melakukan penyuluhan untuk pertanian, perikanan dan kehutanan. Di Kabupaten Sumbawa penyuluh polivalen pernah dicoba namun tidak berjalan efektif. Hal tersebut disebabkan pengetahuan penyuluh masih terspesialisasi pada satu sektor. Sehingga saat ini, penyuluh melakukan penyuluhan kembali ke spesialisasinya yaitu penyuluh pertanian memberikan penyuluhan pertanian; penyuluh perikanan melakukan penyuluhan perikanan dan penyuluh kehutanan melakukan penyuluhan kehutanan.

Secara umum ketiga lokasi studi, jumlah penyuluh masih cukup rendah dibandingkan dengan desa yang harus didampinginya. Terkhusus penyuluh kehutanan, di ketiga lokasi studi memiliki jumlah yang terbatas, yaitu 22 orang (lelaki semua) di Kabupaten Sumbawa, 22 orang (20 lelaki dan 2 perempuan) di Kabupaten Gunungkidul, dan 16 orang (12 lelaki dan 4 perempuan) di Kabupaten Timor Tengah Selatan (Gambar 5). Hal yang menarik adalah rata-rata umur penyuluh tersebut di atas 45 tahun. Ketidakseimbangan proporsi penyuluh muda dan tua bisa mengakibatkan tidak adanya proses regenerasi dari para penyuluh yang sudah tua, sehingga keberlanjutan penyuluhan kehutanan yang efektif menjadi terhambat. 
Dalam diskusi kelompok di Kabupaten Sumbawa, penyuluh yang telah berusia di atas 50 tahun menyatakan bahwa motivasi mereka dalam memberikan penyuluhan sudah berkurang, hal tersebut disebabkan oleh kondisi fisik yang tidak mendukung jika melakukan perjalanan jauh. Jangkauan wilayah kerja di Kabupaten Sumbawa dan Timor Tengah Selatan relatif jauh dengan kondisi jalan yang rusak dan berbukit.

Masa pensiun juga menjadi permasalahan ketika tidak ada penerimaan dan regenerasi penyuluh. Dalam 5 tahun ke depan diperkirakan jumlah penyuluh akan berkurang banyak, jika tidak ada rekrutmen atau regenerasi. Penambahan masa kerja bagi penyuluh juga tidak efektif, karena kegiatan penyuluhan terutama di wilayah yang terpencil membutuhkan tenaga penyuluh yang dinamis dan bermotivasi tinggi.

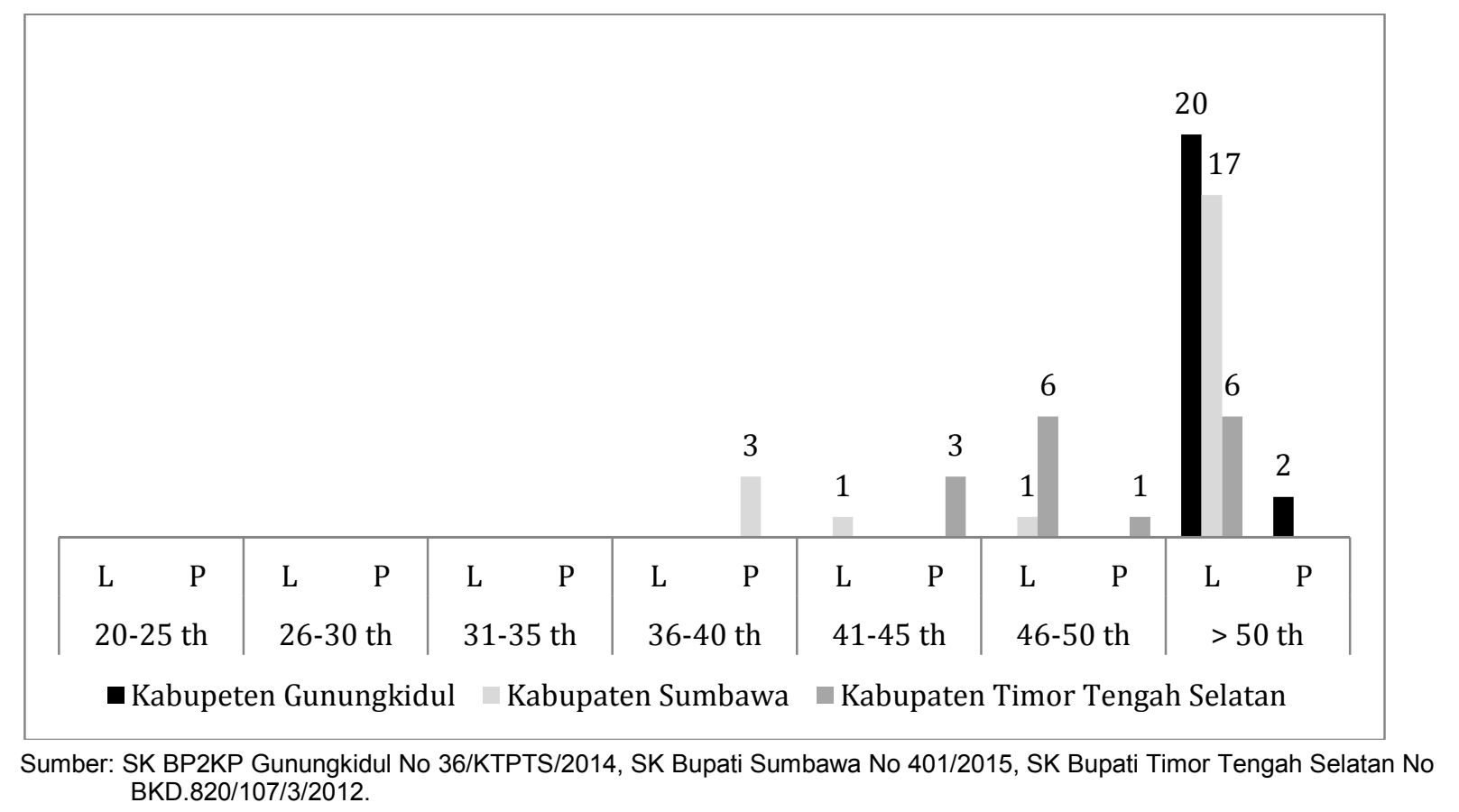

Gambar 5. Jumlah penyuluh PNS di Kabupaten Sumbawa, Kabupaten Gunungkidul dan Kabupaten Timor Tengah Selatan berdasarkan usia dan jenis kelamin

Dari sisi pendidikan, penyuluh kehutanan di ketiga lokasi studi sebagian besar berpendidikan Sekolah Penyuluh Kehutanan atau setingkat Sekolah Menengah Atas (SMA) (Gambar 6.). Di Kabupaten Gunungkidul ada 14 orang (63,6\%); Kabupaten Sumbawa 12 orang $(54,6 \%)$; dan Kabupaten Timor Tengah Selatan 13 orang (81,3\%). Dilihat dari data, angka tertinggi untuk penyuluh kehutanan yang berpendidikan SPK/SMA ada di Kabupaten Timor Tengah Selatan (81,3\%). Penyuluh yang berpendidikan sarjana/strata 1 tertinggi dari ketiga kabupaten ada di Kabupaten Sumbawa dengan jumlah 10 orang (45,5\%); kemudian Kabupaten Gunungkidul 8 orang (36,4\%) dan Kabupaten Timor Tengah Selatan 3 orang $(18,8 \%)$. 


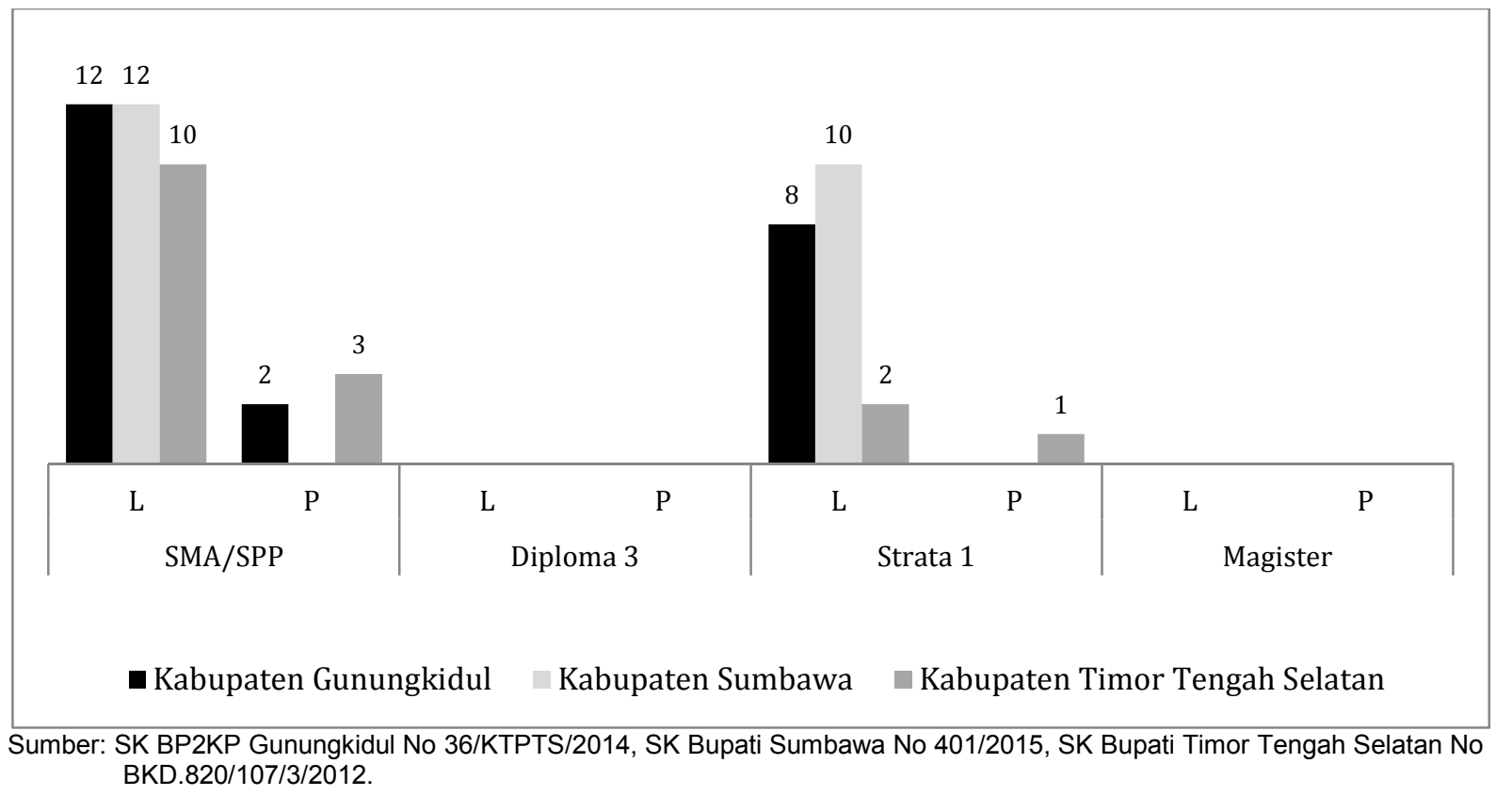

Gambar 6. Jumlah penyuluh kehutanan di Kabupaten Gunungkidul, Kabupaten Sumbawa dan Kabupaten Timor Tengah Selatan berdasarkan tingkat pendidikan dan jenis kelamin.

Tingkat pendidikan sering digunakan sebagai indikator kualitas Sumber Daya Manusia (SDM), terlepas dari pengalaman kerja dan pendidikan non formal lainya. Untuk meningkatkan kualitas SDM penyuluh di ketiga kabupaten, yang terlihat nyata adalah di Kabupaten TTS yang telah mengirimkan 3 penyuluh kehutanannya untuk tugas pendidikan menyelesaikan program sarjana. Bentuk peningkatan kapasitas penyuluh yang sering dilakukan di ketiga kabupaten yaitu bimbingan teknis dan pelatihan yang diselenggarakan balai pelatihan maupun pemerintah daerah.

\subsubsection{Penyuluh Tenaga Harian Lepas}

Penyuluh Tenaga Harian Lepas (THL) di ketiga kabupaten lokasi studi hanya ada untuk sektor pertanian yaitu Tenaga Harian Lepas Tenaga Bantu Penyuluh Pertanian (THL-TBPP) yang direkrut oleh Kementerian Pertanian menggunakan Anggaran Pendapatan dan Belanja Negara (APBN). THLTBPP bertugas membantu penyuluhan BP4K, dimana wilayah kerjanya diatur melalui Surat Keputusan Bupati atau Surat Keputusan Badan Pelaksanaan Penyuluhan. Pada sektor kehutanan tidak ada penyuluh THL terdaftar di ketiga kabupaten.

\subsubsection{Penyuluh Swadaya}

Penyuluh swadaya adalah petani yang berhasil dalam usahanya atau warga masyarakat lainnya yang dengan kesadarannya sendiri mau dan mampu menjadi penyuluh. Penyuluh swadaya di sektor kehutanan dikenal dengan Penyuluh Kehutanan Swadaya Masyarakat (PKSM). 
Menurut Riyadi (42 th, lelaki) dirinya menjadi penyuluh swadaya diajukan oleh Dinas Kehutanan dan Perkebunan Kabupaten Gunungkidul dan disahkan dengan Surat Keputusan Kepala BP2KP Kabupaten Gunungkidul. Saat ini ada sebanyak 33 PKSM yang tersebar di 18 kecamatan di Kabupaten Gunungkidul. Selama ini Riyadi melakukan kegiatan penyuluhan kehutanan yang ada di sepanjang Pantai Kukup, Kecamatan Tanjungsari, Kabupaten Gunungkidul. Beliau mengajak petani lain untuk melakukan kegiatan penghijauan dan budidaya di sepanjang pantai. Kegiatan penyuluhan yang pernah dilakukan oleh Riyadi antara lain: teknis penanaman sengon laut (Paraserianthes falcataria); teknis penanaman nyamplung atau bintangur (Calophyllum inophyllum); penanaman jahe emprit (Zingiber officinale var.amarum) di bawah tegakan sengon laut; dan pendampingan kebun bibit rakyat.

Untuk Kabupaten Sumbawa, penyuluh kehutanan PNS yang berjumlah 22 orang dianggap belum bisa melingkupi petani yang ada di semua kecamatan. Oleh karena itu pada tahun 2013 pemerintah Kabupaten Sumbawa melalui Surat Keputusan Kepala Badan Pelaksana Penyuluhan Pertanian, Perikanan, dan Kehutanan (BP4K), menunjuk dan menetapkan penyuluh kehutanan swadaya. Penyuluh swadaya tersebut bertugas membantu pelaksanaan penyuluhan di tingkat kecamatan tempat tinggalnya. Penyuluh kehutanan swadaya yang ditunjuk dan ditetapkan oleh Kepala BP4K sebanyak 35 orang yang semuanya laki- laki, dan khusus untuk Kecamatan Unter Iwes dan Kecamatan Batulanteh masing-masing ditunjuk 30 PKSM. Kegiatan pokok dari PKSM adalah melaksanakan dan mendampingi pembuatan kebun bibit rakyat dan penanaman hutan rakyat yang menjadi program BP4K dan Dinas Kehutanan dan Perkebunan Kabupaten Sumbawa.

Penyuluh kehutanan swadaya masyarakat di Kabupaten Timor Tengah Selatan menurut Mariah Elisabeth Magang (perempuan, 43 th), koordinator penyuluh kehutanan Kabupaten Timor Tengah Selatan, ada satu orang di setiap kelurahan/desa. Penyuluh kehutanan swadaya tersebut belum ditetapkan melalui Surat Keputusan Bupati ataupun Surat Keputusan Kepala Badan Pelaksana Penyuluhan. Penyuluh kehutanan swadaya bertugas membantu pelaksanaan penyuluh kehutanan di kelurahan/desa masing-masing seperti pendampingan hutan rakyat, monitoring kegiatan penghijauan rehabilitasi dan konservasi yang dilaksanakan oleh Dinas Kehutanan dan Badan Ketahanan Pangan dan Penyuluhan Kabupaten Timor Tengah Selatan. Selama ini penyuluh swadaya dikoordinasi oleh penyuluh kehutanan di masing-masing BP3K.

Jumlah tenaga penyuluh kehutanan yang kurang seharusnya dapat didukung dengan adanya penyuluh swadaya, namun pengelolaan penyuluh swadaya di kabupaten masih perlu banyak perbaikan.

Peningkatan kapasitas bagi penyuluh swadaya saat ini masih kurang bahkan tidak ada.

\subsection{Program Penyuluhan}

Program penyuluhan adalah rencana tertulis yang disusun secara sistematis untuk memberikan arah dan pedoman sebagai alat pengendali pencapaian tujuan penyuluhan (UU No. 16/2006). Menyusun 
program penyuluhan merupakan salah satu fungsi dari kelembagaan penyuluhan di tingkat pusat, provinsi, kabupaten dan kecamatan. Studi ini menyajikan dan membahas program penyuluhan kehutanan. Dalam Peraturan Menteri Kehutanan (Permenhut) Nomor 78 tahun 2014, bentuk program penyuluhan kehutanan secara umum terdiri dari matrik dan narasi. Matrik program penyuluhan seperti matrik program kegiatan pada umumnya yang terdiri dari: keadaan wilayah; tujuan penyuluhan; permasalahan; sasaran penyuluhan; dan cara mencapai tujuan penyuluhan. Cara mencapai tujuan penyuluhan ini akan diturunkan dalam kegiatan penyuluhan dimana ada acuan tentang materi penyuluhan, metode, lokasi penyuluhan, waktu pelaksanaan, rencana pembiayaan, sumber pembiyaan, pelaksana dan penanggung jawab.

\subsubsection{Mekanisme penyusunan program penyuluhan}

Penyusunan program penyuluhan di tingkat kecamatan difasilitasi oleh Kepala BP3K, yang disusun oleh penyuluh bersama perwakilan pelaku utama (petani) dan pelaku usaha. Penyusunan program penyuluhan dimulai dengan mengidentifikasi potensi wilayah dengan menggunakan metode dan alat seperti Participatory Rural Appraisal (PRA), Impact Point, Focus Group Discussion (FGD) atau teknik identifikasi keadaan wilayah lainnya.

Penyusunan program penyuluhan di tingkat kabupaten/kota difasilitasi oleh Kepala BP4K, yang diikuti oleh penyuluh bersama perwakilan pelaku utama dan pelaku usaha. Penyusunan di kabupaten dimulai dengan melakukan rekapitulasi program penyuluhan tingkat kecamatan (Permenhut No. 78/2014, tentang Pedoman Penyusunan Program Penyuluhan Kehutanan).

Mekanisme penyusunan program penyuluhan di Kabupaten Gunungkidul dimulai dengan melakukan identifikasi potensi wilayah di desa. Pelibatan pelaku utama melalui perwakilan kelompok tani dan gabungan kelompok tani juga telah dilakukan untuk mengidentifikasi potensi dan menyusun rencana penyuluhan di tingkat desa. Pelibatan pelaku usaha, penyuluh swasta dan penyuluh swadaya masih belum dilakukan di wilayah Kabupeten Gunungkidul. Proses penyusunan program penyuluhan ini dilakukan kurang lebih tiga bulan dimulai bulan Februari-April setiap tahunnya.

Di Kabupaten Sumbawa program penyuluhan disusun untuk satu tahun. Berdasarkan dari program penyuluhan tersebut penyuluh menyusun rencana kerja tahunan yang akan digunakan sebagai dasar pelaksanaan kegiatan penyuluhan di masing-masing wilayah kerjanya.

Di Kabupaten Timor Tengah Selatan mekanisme penyusunan program penyuluhan ada dua jalur yaitu: jalur internal BKP2 dan jalur Musyawarah Perencanaan Pembangunan (musrenbang). Program penyuluhan yang disusun di internal Badan Ketahanan Pangan dan Penyuluhan (BKP2) dimulai dari persiapan rancangan rencana penyuluhan di masing-masing bidang. Rencana masing-masing bidang akan dibahas dalam gelaran rapat BKP2. Hasil gelar rapat akan dibahas kembali dengan Kepala BKP2 bersama tim program, setelah disetujui Kepala BKP2, maka program penyuluhan diajukan ke Badan 
Perencanaan Daerah untuk diajukan ke Rapat Anggaran DPRD. Jalur musrenbang dilakukan dengan mekanisme bertahap mulai dari musrenbang desa hingga musrenbang kabupaten. Jalur musrenbang ini melibatkan multi pihak pada setiap tingkatan wilayah administrasi.

\subsubsection{Program Penyuluhan Kehutanan Kabupaten Gunungkidul}

Menurut Sugeng Raharjo (laki-laki, 53th) sekretaris BP2KP Gunungkidul, setiap tahunnya BP2KP menyusun program penyuluhan yang terdiri dari program penyuluhan pertanian, program penyuluhan perikanan dan program penyuluhan kehutanan. Dalam studi ini akan disajikan penjabaran dari salah satu contoh matrik program penyuluhan kehutanan di BP2KP Kabupaten Gunungkidul. Penjabaran matrik program diambil dari program penyuluhan Kabupaten Gunungkidul tahun 2014, sebagai acuan program penyuluhan yang telah dilaksanakan.

Program penyuluhan kehutanan di Kabupaten Gunungkidul meliputi lima aspek yaitu: teknis budidaya tanaman kehutanan; pengendalian aliran permukaan; kelembagaan kelompok tani kehutanan; ekonomi kehutanan; dan kesejahteraan petani (Lampiran 1).

Tujuan penyuluhan kehutanan di BP2KP Kabupaten Gunungkidul lebih pada meningkatkan pengetahuan petani terutama pada aspek teknis budidaya tanaman kehutanan dan aspek pengendalian aliran permukaan. Perubahan sikap dan peningkatan keterampilan masih belum terlihat dari kedua aspek tersebut jika dilihat dari tujuan penyuluhan. Hal yang akan dicapai dalam proses penyuluhan adalah adanya perubahan pengetahuan (kognisi), keterampilan (psikomotorik) dan sikap (afeksi). Salah satu hal yang penting dalam mencapai tujuan penyuluhan adalah materi yang sesuai dan metode penyuluhan yang digunakan. Dari materi penyuluhan (Lampiran 1.) terlihat bahwa materi bertujuan untuk meningkatkan pengetahuan dan keterampilan (teknis). Metode penyuluhan yang digunakan dalam program penyuluhan sebagian besar adalah ceramah, diskusi, demontrasi plot (Lampiran 1), dimana metode-metode tersebut lebih sering digunakan untuk meningkatkan pengetahuan peserta penyuluhan. Pelatihan dan temu usaha biasa digunakan untuk menyebarluaskan teknologi dan meningkatkan motivasi yang mempengaruhi perubahan sikap dari petani. Hal penting dari perubahan sikap petani tidak lepas dari proses pendampingan yang intensif dan berkelanjutan.

Sumber anggaran program penyuluhan kehutanan BP2KP Kabupeten Gunungkidul berasal dari Anggaran Pendapatan dan Belanja Daerah (APBD) Kabupaten Gunungkidul; APBD Provinsi Daerah Istimewa Yogyakarta; Dana Keistimewaan; Anggaran Pendapatan dan Belanja Negara (APBN); dana alokasi khusus dan swadaya. Anggaran tersebut dialokasikan dan dikelola oleh beberapa lembaga yang juga bertindak sebagai pelaksana kegiatan penyuluhan di bawah pengawasan dan koordinasi BP2KP Kabupaten Gunungkidul. Pelaksana program penyuluhan kehutanan di Kabupaten Gunungkidul yaitu: BP2KP Kabupaten Gunungkidul, Dinas Kehutanan dan Perkebunan Kabupaten 
Gunungkidul, Bina Pengelolaan Daerah Aliran Sungai, Kelompok Tani Kehutanan dan Kelompok Tani Penghijauan.

\subsubsection{Program Penyuluhan Kehutanan Kabupaten Sumbawa.}

Focus Group Discussion (FGD) dengan penyuluh kehutanan Kabupaten Sumbawa diperoleh informasi bahwa program penyuluhan disusun untuk satu tahun. Selama ini program penyuluhan kehutanan Kabupaten Sumbawa disusun oleh masing-masing penyuluh kehutanan di BP3K.

Dokumentasi tentang program penyuluhan dalam lima tahun terakhir tidak diperoleh melalui studi ini. Pada proses FGD hanya diperoleh informasi tentang program penyuluhan kehutanan Kabupeten Sumbawa tahun 2016, yang baru selesai disusun dan diajukan ke BP4K oleh Koordinator Penyuluh Kehutanan Kabupaten Sumbawa. Program penyuluhan kehutanan tahun 2016 tidak terlalu relevan untuk melihat kegiatan penyuluhan kehutanan yang telah dilakukan oleh BP4K di Kabupaten Sumbawa. Penyajian program penyuluhan kehutanan tahun 2016 bisa digunakan untuk melihat kebutuhan dan tantangan penyuluhan kehutanan di Kabupaten Sumbawa. Garis besar program penyuluhan kehutanan di Kabupaten Sumbawa disajikan pada Lampiran 2.

Tujuan penyuluhan kehutanan di Kabupaten Sumbawa jika dikelompokkan terdiri dari aspek konservasi hutan dan sumber daya air, teknik budidaya tanaman hutan, hasil hutan bukan kayu, kelembagaan kelompok tani dan regulasi penatausahaan hutan hak. Tujuan program penyuluhan Kabupaten Sumbawa adalah untuk meningkatkan kesadaran, kemampuan, perilaku dan sikap dari petani. Jika melihat dari metode yang digunakan adalah ceramah, diskusi, dan demonstrasi, dimana metode tersebut digunakan untuk meningkatkan pengetahuan dan motivasi petani ke arah perubahan kesadaran. Untuk melakukan perubahan keterampilan umumnya menggunakan metode bimbingan dan pelatihan teknis. Sedangkan untuk perubahan sikap umumnya memerlukan waktu yang lebih panjang dengan proses pendampingan yang intensif dan berkelanjutan.

Sumber anggaran program penyuluhan kehutanan Kabupaten Sumbawa berasal dari APBD Kabupaten Sumbawa, APBD Provinsi Nusa Tenggara Barat dan APBN. Berdasarkan sumber anggaran tersebut program penyuluhan kehutanan di Kabupaten Sumbawa pelaksanaannya dilakukan oleh BP3K/BP4K Kabupaten Sumbawa, Dinas Kehutanan dan Perkebunan Kabupaten Sumbawa dan Kesatuan Pengelolaan Hutan (KPH) di bawah Kementerian Lingkungan Hidup dan Kehutanan.

\subsubsection{Program Penyuluhan Kehutanan Kabupaten Timor Tengah Selatan.}

Dokumen program penyuluhan kehutanan di Kabupeten Timor Tengah Selatan tidak diperoleh pada kegiatan studi ini. Informasi tentang kegiatan penyuluhan kehutanan yang telah dilakukan di Kabupaten Timor Tengah Selatan dalam lima tahun terakhir (2010-2015) diperoleh dari wawancara dengan Mariah Elisabeth Magang (perempuan, 43 th), koordinator penyuluh kehutanan Kabupaten 
Timor Tengah Selatan. Kegiatan penyuluhan yang dilakukan di Kabupaten Timor Tengah Selatan berdasarkan dari hasil wawancara yaitu:

a. Budidaya lebah madu, dilakukan di Kecamatan Nae bebu. Metode penyuluhan ini dilakukan dengan kunjungan, ceramah dan diskusi dengan petani lebah.

b. Pengembangan lebah madu, dilakukan di Kecamatan Amanuban Tengah, dilakukan dengan pendampingan kelompok lebah madu.

c. Pengembangan ulat sutra dilakukan pada tahun 2010-2011 di Kecamatan Soe. Kegiatan dilakukan oleh Dinas Kehutanan dengan memberikan bantuan telur ulat sutera dan pendampingan kelompok budidaya ulat sutera.

d. Budidaya tanaman kehutanan, materi ini tergantung pada musim. Jika musim kemarau dilakukan untuk budidaya tanaman untuk konservasi. Pada musim penghujan penyuluhan dilakukan kolaborasi dengan penyuluh tanaman pangan untuk materi tanaman sela.

e. Kegiatan demonstrasi plot hutan rakyat, dilakukan setiap tahun di masing-masing kecamatan.

Sumber anggaran penyuluhan pada program penyuluhan di Kabupaten Timor Tengah Selatan berasal dari APBD Kabupaten, APBD Provinsi, APBN. Pada rentang waktu 2010-2011 sebelum BKP2 Kabupaten Timor Tengah Selatan dibentuk pelaksanaan penyuluhan kehutanan di bawah koordinasi Dinas Kehutanan dan Perkebunan. Setelah tahun 2012-2015 pelaksana penyuluhan dilakukan BKP2 yang masih berkoordinasi dengan Dinas Kehutanan dan Perkebunan Kabupaten Timor Tengah Selatan.

\subsubsection{Program Penyuluhan dari Lembaga Lain}

Kerja penyuluhan di ketiga lokasi studi selain dilaksanakan oleh lembaga penyuluhan pemerintah juga dilaksanakan oleh lembaga penyuluh swasta maupun lembaga pemerintah lainnya. Kerja penyuluhan yang dilakukan oleh lembaga-lembaga tersebut cukup berpengaruh terhadap peningkatan pengetahuan, keterampilan dan sikap petani di wilayah studi. Gambaran lembaga tersebut dan programnya sebagai berikut:

\section{Lembaga Penyuluhan Swasta di Kabupaten Gunungkidul}

\section{a. PT. Rimba Partikel Indonesia}

PT. Rimba Partikel Indonesia merupakan salah satu anak perusahaan Sumitomo Group. Program penyuluhan PT. Rimba Partikel Indonesia yaitu tentang Pelestarian Suaka Margasatwa Paliyan dan Penanaman kayu di luar Kawasan Suaka Margasatwa Paliyan. Bentuk kegiatan penyuluhan yang dilakukan oleh PT. Rimba Partikel Indonesia menurut Gunawan Setiaji (laki-laki, 40 th)-manajer proyek PT. Rimba Partikel Indonesia- adalah kampanye tentang pelestarian Suaka Margasatwa 
Paliyan dan pendampingan pembibitan tanaman kayu bagi petani mitra. Pendampingan tersebut meliputi: penyiapan benih, pengolahan lahan dan pemupukan. Kampanye pelestarian Suaka Margasatwa Paliyan dilakukan bersama Balai Konservasi Sumber Daya Alam (BKSDA) Yogyakarta, dengan melakukan pertemuan warga dan presentasi di balai desa penyangga kawasan sebulan sekali. Kampanye tersebut menggunakan media film, slide presentasi dan brosur. Wilayah kerja penyuluhan PT. Rimba Partikel Indonesia berada di empat desa yaitu: Desa Karangduwet dan Desa Karangasem di Kecamatan Paliyan; Desa Jetis dan Desa Nglipar di Kecamatan Saptosari. Desa Karangduwet merupakan salah satu wilayah studi ini. Dalam melakukan kegitan penyuluhan PT. Rimba Partikel Indonesia didukung oleh tujuh penyuluh yang semuanya laki-laki. Penyuluh ini direkrut dari sekitar desa penyangga kawasan Suaka Margasatwa Paliyan.

\section{b. Perkumpulan ARUPA (Aliansi Relawan Untuk Penyelamatan Alam)}

Perkumpulan ARUPA merupakan satu lembaga yang melakukan kegiatan penyuluhan kehutanan di Kabupaten Gunungkidul. Program penyuluhan lembaga ini meliputi: pelestarian sumber daya alam, microfinance, sistem verivikasi legalitas kayu dan pendampingan hasil hutan kayu. Fokus pendampingan lembaga ini dilakukan pada petani hutan rakyat di Kecamatan Nglipar, Dengok, dan Panggang. Perkumpulan ARUPA memiliki enam penyuluh-fasilitator yang terdiri dari empat laki-laki dan dua perempuan. Metode yang digunakan penyuluh-fasilitator yaitu:(i) pertemuan warga guna memetakan kebutuhan dan menyusun rencana kegiatan; (ii) pelatihan bagi pelatih (Training of Trainer); (iii) bimbingan teknis; (iv) studi banding. Guna lebih mendalami karakteristik petani dan wilayah, penyuluh-fasilitator Perkumpulan ARUPA menggunakan pendekatan tinggal di wilayah dampingan. Media penyuluhan yang diproduksi dan digunakan oleh Perkumpulan ARUPA antara lain: slide presentasi, film tutorial, buku, dan brosur.

\section{c. Perhimpunan Shorea}

Perhimpunan Shorea melakukan penyuluhan melalui pendekatan pendampingan hutan rakyat, hutan kemasyarakatan $(\mathrm{HKm})$ dan hutan desa. Materi penyuluhan yang disampaikan kepada petani antara lain: pengelolaan hutan rakyat yang lestari; penguatan kelembagaan petani kehutanan; kelola usaha dan kelola kawasan. Perhimpunan Shorea memiliki tiga penyuluh-fasilitator yang ditinggal di wilayah kerja guna melakukan pendekatan ke petani. Saat melakukan tugas di wilayah kerja penyuluhfasilitator menyelenggarakan pertemuan rutin dan pertemuan khusus yang terjadwal dengan paguyuban petani. Selain melakukan pertemuan rutin, kegiatan penyuluhan yang dilakukan adalah: pelatihan, temu usaha, dan kunjungan belajar. Wilayah kerja Perhimpunan Shorea di Kabupaten Gunungkidul yaitu: Kecamatan Dengok, Kecamatan Wonosari, Kecamatan Semanu, Kecamatan Tepus, Kecamatan Giriselo dan Kecamatan Saptosari. 


\section{d. International Centre Research of Agroforestry (ICRAF) dan Center of International Forestry Research (CIFOR)}

ICRAF yang bermitra dengan CIFOR menjalankan proyek penelitian tentang jati yang didanai oleh Australian Centre for International Agriculture Research (ACIAR) pada tahun 2007-2011. Tujuan dari proyek tersebut yaitu: memperkenalkan teknologi dan adaptasi teknologi silvikultur guna meningkatkan produksi jati petani kecil; mengidentifikasi dan merancang skema keuangan yang intensif bagi petani kecil untuk produksi jati yang menguntungkan; dan meningkatkan akses pasar bagi hasil jati petani kecil. Proyek penelitian ini dilaksanakan di 8 desa di Kabupaten Gunungkidul. Beberapa kegiatan peningkatan kapasitas yang dilakukan oleh proyek ini melalui: kunjungan lapangan; pelatihan; pendampingan kepada organisasi keuangan petani. Pelatihan yang dilakukan oleh proyek ini pada aspek produksi berupa teknik budidaya tanaman jati dalam kegiatan Kunjungan Lapang atau Farmer Field Day. Dalam FGD di Desa Bejiharjo dan Desa Karangduwet petani menyatakan mereka mengetahui teknik pemangkasan cabang dan penjarangan pohon dari pelatihan dan kunjungan belajar yang difasilitasi oleh ICRAF.

\section{Lembaga Penyuluhan Swasta di Kabupaten Sumbawa \\ a. WWF Indonesia}

WWF Indonesia program Nusa Tenggara pada tahun 2010-2015 menjadi mitra pelaksana dalam dua proyek yang di danai ACIAR di wilayah Sumbawa. Proyek tersebut yaitu Community Based Commercial Forestry (CBCF) (2011-2015) dan Development of timber and non-timber forest products' production and marketing strategies for improvement of smallholders' livelihoods in Indonesia (2013-2016). Dalam proyek CBCF di Sumbawa WWF bekerjasama dengan pemerintah Kabupaten Sumbawa pada 28 April-2 Mei 2014 melakukan program pelatihan Master Tree Grower (MTG) di Desa Semamung Kecamatan Moyo Hulu Kabupaten Sumbawa. Master Tree Grower merupakan sebuah pelatihan bagi petani untuk mengoptimalkan pertumbuhan tanaman kayu sehingga menghasilkan kayu yang baik secara kuantitas dan kualitas. Peserta dari pelatihan MTG selain memiliki kemampuan membudidaya tanaman kayu yang baik untuk diri sendiri juga dapat menjadi tutor atau pendamping bagi petani lain yang tidak mengikuti pelatihan.

Dalam Proyek Development of timber and nontimber forest product' production and marketing strategies for improvement of smallholders' livelihoods in Indonesia, WWF Indonesia menginisiasi pemebentukan kelompok kerja kebijakan kayu dan hasil hutan bukan kayu di Kabupaten Sumbawa. WWF Indonesia juga melakukan pendampingan untuk peningkatan kapasitas dan penguatan kelembagaan kelompok kerja tersebut. 


\section{b. Kesatuan Pengelolaan Hutan (KPH) Sumbawa}

KPH Sumbawa dibagi dalam dua wilayah kerja yaitu KPH Batulanteh dan KPH Puncak Ngengas. Wilayah kerja KPH Batulanteh meliputi delapan kecamatan dimana diantaranya adalah lokasi studi yaitu: Kecamatan Batulanteh dan Kecamatan Unter Iwes.

Rencana dan kegiatan yang pernah dan akan dilaksanakan oleh KPH Batulanteh berfokus pada rencana pengelolaan hutan produksi dan rencana pengelolaan hutan lindung. Rencana pengelolaan hutan produksi meliputi: inventarisasi kawasan hutan produksi; pemeliharaan tegakan pada hutan produksi; rehabilitasi pada hutan produksi bekas penjarahan; pengembangan tanaman kayu putih untuk mengoptimalkan lahan kritis; optimalisasi pemanfaatan lahan di bawah tegakan. Rencana pengelolaan hutan lindung: melaksanakan identifikasi perubahan, memantau dan evaluasi perkembangan hutan lindung secara berkala minimal satu tahun sekali; melakukan penyusunan rencana reboisasi pada kawasan hutan lindung; melibatkan masyarakat desa dalam pengelolaan kawasan hutan lindung; dan memberikan alokasi hutan kemasyarayakatan ( $\mathrm{HKm})$ untuk masyarakat desa (KPH 2012).

\section{c. Jaringan Madu Hutan Sumbawa (JMHS)}

Jaringan Madu Hutan Sumbawa (JMHS) merupakan salah satu jaringan dari Jaringan Madu Hutan Indonesia (JMHI). JMHS pada awalnya diinsisiasi oleh beberapa pengumpul madu hutan di Sumbawa dan difasilitasi oleh KPH Sumbawa dalam berjejaring dengan JMHI. JMHI memberikan pendampingan dan peningkatan kapasitas anggota JMHS dalam teknik pengolahan madu, keorganisasian dan pemasaran. Saat ini JMHS telah dapat beroperasi dan melakukan beberapa kegiatan penyuluhan bagi pengumpul/petani madu di Kabupaten Sumbawa. Kegiatan penyuluhan yang pernah dilakukan oleh JMHS di Desa Batudulang berdasar FGD dengan petani yaitu: pelatihan membuat lilin dari madu; pembuatan sabun berbahan madu; pengelolaan madu hutan dengan cara tiris sampai dengan pengemasan; pendampingan pemasaran hasil madu hutan melalui koperasi di wilayah Sumbawa hingga Jakarta. Salah satu wilayah yang menjadi tempat kegiatan penyuluhan JMHS yang juga menjadi lokasi studi yaitu Desa Batudulang, Kecamatan Batulanteh, Sumbawa.

\section{d. UD. Makassar Utama}

UD. Makassar Utama adalah satu-satunya industri primer di Kabupaten Sumbawa. Sebagai industri primer yang menerima kayu dari petani, UD. Makassar Utama juga merasa berkepentingan untuk memperoleh kualitas dan kuantitas kayu yang bagus dan legal dari petani. Maka dari itu UD.

Makassar Utama melakukan pendampingan bagi petani yang menjadi mitranya dalam hal pengurusan surat-surat legalitas kayu (Ijin Pemanfaatan Kayu Tanah Milik atau Surat Keterangan Asal Usul Kayu). UD. Makassar Utama juga melakukan pendampingan kepada pemuda Desa Semamung, Kecamatan Moyo Hulu dalam pengolahan limbah kayu menjadi mebel atau peralatan rumah tangga. 
UD. Makkassar Utama selain bekerjasama dengan Desa Semamung juga membuka peluang untuk bekerjasama dengan desa lain.

\section{Lembaga Penyuluhan Swasta di Kabupaten Timor Tengah Selatan \\ a. Yayasan Mitra Tani Mandiri (YMTM)}

Berdasarkan diskusi kelompok terarah diperoleh informasi bahwa lembaga ini secara rutin mendampingi petani di Desa Fatumnasi dalam bidang pengembangan pertanian terpadu (pertanian, peternakan dan kehutanan). Lembaga ini berkantor di Jalan Basuki Rahmat, Kefamenanu, Kabupaten Timor Timur Utara. Salah satu responden petani menyampaikan bahwa kegiatan yang dilakukan YMTM di Desa Fatumnasi yaitu: (i) mendampingi petani dalam membuat rencana kerja kelompok; (ii) mendampingi pertemuan rutin sebagai kelas pembelajaran pertanian; (iii) melakukan pendampingan teknis dalam hal budidaya pertanian, manajemen ternak; (iv) melakukan pendampingan pemasaran hasil pertanian dan peternakan yang berkeadilan. Dalam melaksanakan programnya YMTM menugaskan satu fasilitator untuk tinggal di Desa Fatumnasi.

\section{b. Sanggar Suara Perempuan (SSP) Soe}

Merupakan pusat informasi dan komunikasi gender yang berkantor di jalan Beringin No.1 Kesetnana, Soe, Kabupaten Timor Tengah Selatan. Lembaga ini melakukan pendampingan bagi kaum perempuan di Desa Bosen, Mollo Utara, melalui pendekatan pendampingan pertanian skala rumah tangga bagi kaum perempuan. Dari FGD yang dilakukan di Desa Bosen diperoleh informasi tentang kegiatan Sanggar Suara Perempuan Soe antara lain: bantuan pupuk, bantuan mesin air, dan pendampingan teknis budidaya tanaman pangan. Sanggar Suara Perempuan Soe secara rutin melakukan kegiatan di Desa Bosen dengan durasi satu sampai tiga bulan sekali.

\section{c. WWF Indonesia}

WWF Indonesia program Nusa Tenggara menjalankan program hasil hutan bukan kayu di wilayah Gunung Mutis, Kabupaten Timor Tengah Selatan. Lembaga ini menginisiasi pembentukan kelompok pengumpul madu alam di desa-desa penyangga Cagar Alam Gunung Mutis. WWF juga melakukan pendampingan teknis untuk pengolahan madu alam sampai dengan pemasarannya. Salah satu yang sampai sekarang masih berjalan adalah Jaringan Kelompok Masyarakat Mutis, dimana salah satu kegiatannya adalah pemasaran madu alam. WWF Indonesia di Provinsi Nusa Tenggara Timur berkantor di Jalan Srikandi No 6 Kota Kupang. 


\section{d. Helen Keller International - Indonesia (HKI-Indonesia)}

Salah satu lembaga non pemerintah yang berkerja untuk isu kesehatan, nutrisi dan pendidikan. Di Kabupaten Timor Tengah Selatan HKI-Indonesia menjalankan program produksi pangan skala rumah tangga dan pendidikan nutrisi sejak tahun 2012. Dari wawancara dengan Program Koordinator HKI Indonesia di Soe -Ibu Dian-, program HKI- Indonesia berfokus pada kegiatan pendidikan nutrisi; pendampingan teknis pertanian dan peternakan skala rumah tangga di 18 Kecamatan dan 66 desa di Kabupaten Timor Tengah Selatan. Kecamatan program HKI-Indonesia yang juga menjadi wilayah kerja Proyek Kanoppi yaitu Kecamatan Fatumnasi (Desa Nuapin, Desa Mutis, Desa Koanoel). Di Kabupaten Timor Tengah Selatan HKI -Indonesia berkantor di Jalan Bougenvile RT 003 RW 02 Kelurahan Soe, Kecamatan Kota Soe.

\subsection{Penyuluhan yang diterima petani}

\subsubsection{Petani yang menerima penyuluhan}

Penerima manfaat penyuluhan adalah para petani, oleh karena itu untuk mengetahui penyuluhan yang diterima petani dalam lima tahun terakhir maka dilakukan wawancara dengan 500 rumah tangga petani di ketiga kabupaten lokasi studi. Dari hasil wawancara, diketahui rata-rata hanya $28 \%$ dari total petani yang diwawancara yang pernah menerima penyuluhan. Persentase tertinggi dari petani yang pernah menerima penyuluhan adalah di Gunungkidul $(41,2 \%)$ dan terendah di Timor Tengah Selatan $(14,7 \%)$ (Gambar 7.).

Rendahnya angka petani yang pernah menerima penyuluhan di Kabupaten Timor Tengah Selatan dikarenakan terbatasnya jumlah penyuluh terutama untuk mencapai desa-desa terpencil seperti dua lokasi desa studi di Kabupaten Timor Tengah Selatan yaitu Fatumnasi dan Bosen. Petani di Desa Bosen, Mollo Utara dalam FGD menginformasikan bahwa sejak tahun 2012 belum ada kegiatan penyuluhan yang dilakukan oleh penyuluh pemerintah. Sejak pergantian penyuluh pada tahun tersebut belum ada lagi penyuluh yang datang ke desa untuk melakukan penyuluhan atau pendampingan ke desa. Sama halnya di Desa Fatumnasi kegiatan penyuluhan dari pemerintah terakhir ada pada tahun 2013, yaitu saat ada kegiatan pembagian bibit kayu cendana (Santalum album) dan jati putih (Gmelina arborea) oleh Dinas Kehutanan Kabupaten Timor Tengah Selatan. Jumlah penyuluh yang kurang juga menjadi tantangan sehingga jumlah petani yang belum pernah menerima penyuluhan cukup tingggi $(>50 \%)$ di ketiga lokasi. Kekurangan jumlah penyuluh pemerintah dinilai belum mampu menjangkau semua wilayah di masing-masing kabupaten terutama di wilayah yang relatif terpencil dan jauh. Peran dari lembaga lain (lembaga swasta dan lembaga swadaya) dinilai membantu dalam kerja penyuluhan di ketiga lokasi yang mempengaruhi jumlah petani yang menerima penyuluhan. 


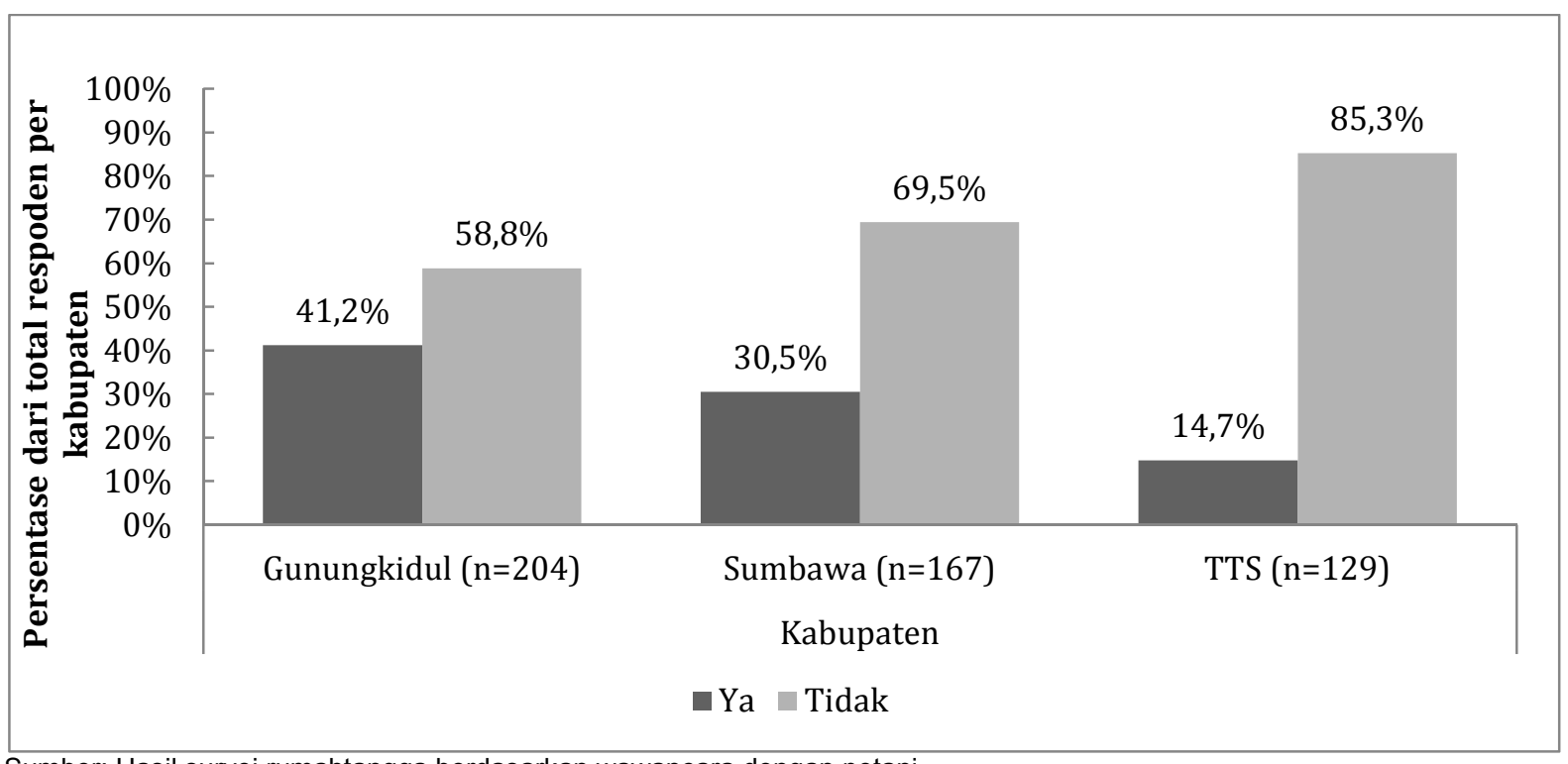

Sumber: Hasil survei rumahtangga berdasarkan wawancara dengan petani

Gambar 7. Petani yang pernah mengikuti penyuluhan dalam lima tahun terakhir di Kabupaten Gunungkidul, Kabupaten Sumbawa, Kabupaten Timor Tengah Selatan.

\subsubsection{Materi Penyuluhan}

Berdasarkan hasil diskusi dengan petani, secara umum di Kabupaten Timor Tengah Selatan, materi penyuluhan yang paling sering diterima oleh petani adalah tentang pertanian. Sedangkan materi penyuluhan tentang kehutanan lebih sering diterima oleh petani di Gunungkidul, seperti materi tentang kayu dan manajemen tanaman kayu. Materi penyuluhan tentang HHBK paling sering diterima oleh petani di Kabupaten Sumbawa. Perbedaan materi di setiap kabupaten menunjukkan kebutuhan dan karakterisktik pola pertanian kehutanan yang berbeda antar lokasi (Tabel 6.).

Di Gunungkidul dapat dikatakan sebagai kabupaten penghasil kayu jati $\left(2.434,70 \mathrm{~m}^{3}\right.$ pada tahun 2013) daripada kedua kabupaten lain. Sehingga kebutuhan informasi tentang kehutanan lebih tinggi. Hal tersebut juga didukung bahwa sebagian besar masyarakatnya mengelola hutan rakyat secara tumpang sari dengan tanaman pangan. Dukungan dari BP2KP, Dinas Kehutanan dan lembaga penyuluh swasta yang melakukan penyuluhan dan penelitian tentang hutan rakyat dan budidaya jati, mempengaruhi materi penyuluhan tentang kehutanan yang sering diterima oleh petani. 
Tabel 6. Materi penyuluhan yang diterima petani di Kabupaten Gunungkidul, Kabupaten Sumbawa dan Kabupaten Timor Tengah Selatan

\begin{tabular}{|c|c|c|c|}
\hline \multirow{2}{*}{$\begin{array}{l}\text { Materi Penyuluhan yang } \\
\text { diterima Petani }\end{array}$} & \multicolumn{3}{|c|}{ Responden yang menerima materi penyuluhan per kabupaten } \\
\hline & Gunungkidul $(n=84)$ & Sumbawa $(n=51)$ & TTS $(n=19)$ \\
\hline Hasil Hutan Bukan Kayu & Tidak spesifik & $\begin{array}{c}15,7 \% \\
\text { (Tentang produksi } \\
\text { madu) }\end{array}$ & $\begin{array}{l}10,5 \% \\
\text { (Tentang pemanenan dan } \\
\text { produksi madu hutan) }\end{array}$ \\
\hline Kehutanan & $\begin{array}{c}34,5 \% \\
\text { (Tentang silvikultur, } \\
\text { pemanenan, hutan } \\
\text { rakyat, Hutan } \\
\text { Kemasyarakatan) }\end{array}$ & $\begin{array}{l}9,8 \% \\
\text { (Tentang pemanenan } \\
\text { kayu dan silvikultur) }\end{array}$ & Tidak spesifik \\
\hline Pertanian & $\begin{array}{c}61,9 \% \\
\text { (Tentang pertanian } \\
\text { secara umum) }\end{array}$ & $\begin{array}{c}66,7 \% \\
\text { (Tentang budidaya } \\
\text { kopi) }\end{array}$ & $\begin{array}{c}73,7 \% \\
\text { (Tentang pertanian secara } \\
\text { umum) }\end{array}$ \\
\hline
\end{tabular}

Sumber: Hasil survei rumahtangga berdasarkan wawancara dengan petani

Di Kabupaten Sumbawa merupakan wilayah yang sedang berkembang untuk pengelolaan hasil hutan bukan kayu seperti madu hutan dan pengembangan lebah trigona, sehingga materi penyuluhan HHBK lebih tinggi di banding kabupaten lain. Jaringan Hutan Madu Sumbawa dan KPH Batulanteh adalah lembaga yang sering menjalankan program penyuluhan tentang madu terutama di Desa Pelat dan Desa Batudulang.

Kabupaten Timor Tengah Selatan adalah salah satu kabupaten dengan pendapatan masyarakatnya pada sektor pertanian, sehingga penyuluhan pertanian yang paling tinggi diterima oleh petani. Selain program penyuluhan pemerintah peran serta lembaga penyuluhan swasta -YMTM, Sanggar Suara Perempuan Soe, dan HKI Indonesia dalam kegiatan penyuluhan berperan dalam penerimaan materi pertanian terutama di wilayah terpencil seperti Mollo Utara dan Fatumnasi.

FGD dan wawancara mendalam yang dilakukan dengan penyuluh dan petani telah mengidentifikasi materi penyuluhan yang pernah diterima petani di ketiga kabupaten adalah: teknik budidaya kehutanan/agroforestri; kayu dan hasil hutan bukan kayu (HHBK); teknologi pengolahan kayu dan HHBK; pemasaran kayu dan HHBK; dan kebijakan yang terkait dengan kayu dan HHBK (Tabel 7.). 
Tabel 7. Hasil identifikasi materi penyuluhan yang pernah diterima petani dalam 5 tahun terakhir di Kabupaten Gunungkidul, Kabupaten Sumbawa dan Kabupaten Timor Tengah Selatan.

\begin{tabular}{|c|c|c|c|}
\hline \multirow{2}{*}{$\begin{array}{l}\text { Materi } \\
\text { Penyuluhan }\end{array}$} & \multicolumn{3}{|c|}{ Kabupaten } \\
\hline & Gunungkidul & Sumbawa & TTS \\
\hline $\begin{array}{l}\text { Teknik Budidaya } \\
\text { Kehutanan/ } \\
\text { Agroforestri }\end{array}$ & $\begin{array}{l}\text { Pengkayaan hutan } \\
\text { rakyat dengan tanaman } \\
\text { jati; } \\
\text { - Silvikultur pada Hutan } \\
\text { Rakyat; } \\
\text { - Budidaya empon-empon } \\
\text { di bawah tegakan } \\
\text { tanaman jati; } \\
\text { - Pembibitan tanaman } \\
\text { mahoni, sengon, akasia. }\end{array}$ & $\begin{array}{l}\text { - Teknik pembibitan } \\
\text { tanaman lokal (Kebun } \\
\text { Bibit Rakyat); } \\
\text { - Silvikultur dan } \\
\text { manajemen kebun jati }\end{array}$ & $\begin{array}{l}\text { Budidaya pinus, } \\
\text { budidaya jati putih } \\
\text { (Gmelina arborea), } \\
\text { budidaya jeruk } \\
\text { keprok, dan budidaya } \\
\text { tanaman sela (jahe, } \\
\text { kunyit) di bawah } \\
\text { tegakan tanaman } \\
\text { kayu (Mollo Utara). } \\
\text { Budidaya kayu } \\
\text { cendana dan jati } \\
\text { putih (Fatumnasi) }\end{array}$ \\
\hline $\begin{array}{l}\text { Kayu dan Hasil } \\
\text { Hutan Bukan } \\
\text { Kayu }\end{array}$ & $\begin{array}{l}\text { Pengembangan hasil } \\
\text { hutan bukan kayu } \\
\text { dengan komoditi bambu } \\
\text { dan madu (Kecamatan } \\
\text { Paliyan dan Kecamatan } \\
\text { Karangmojo); } \\
\text { Budidaya lebah madu. }\end{array}$ & $\begin{array}{l}\text { - Budidaya gaharu dan } \\
\text { lebah madu } \\
\text { - Penyuluhan mengenai } \\
\text { pengembangan lebah } \\
\text { madu Trigona sp dan } \\
\text { Apis cerana } \\
\text { - Tatalaksana pemanenan } \\
\text { madu hutan yang lestari }\end{array}$ & $\begin{array}{l}\text { - Pengelolaan madu } \\
\text { hutan di Kecamatan } \\
\text { Fatumnasi } \\
\text { - } \quad \text { Budidaya tanaman } \\
\text { bamboo } \\
\text { - Pelatihan budidaya } \\
\text { kayu cendana }\end{array}$ \\
\hline $\begin{array}{l}\text { Teknologi } \\
\text { pengolahan kayu } \\
\text { dan HHBK }\end{array}$ & $\begin{array}{l}\text { Pengolahan jahe instan } \\
\text { dan kunyit instan } \\
\text { (Kecamatan Paliyan). } \\
\text { Di Kecamatan } \\
\text { Karangmojo belum } \\
\text { pernah ada. }\end{array}$ & $\begin{array}{l}\text { Pembuatan lilin dan } \\
\text { sabun dari hasil } \\
\text { sampingan madu } \\
\text { (Batudulang). } \\
\text { - Pengolahan madu } \\
\text { dengan cara tiris sampai } \\
\text { dengan pegemasan } \\
\text { (Batudulang). } \\
\text { - Pembuatan jahe instan } \\
\text { (Batudulang). } \\
\text { - Pelatihan ayaman dari } \\
\text { rumput ketak } \\
\text { (Batudulang). }\end{array}$ & $\begin{array}{l}\text { Pengolahan madu } \\
\text { hutan dengan cara } \\
\text { tiris (Fatumnasi). } \\
\text { - Pengolahan jahe dan } \\
\text { kunyit instan } \\
\text { (Fatumnasi). }\end{array}$ \\
\hline $\begin{array}{l}\text { Pemasaran Kayu } \\
\text { dan HHBK }\end{array}$ & $\begin{array}{l}\text { - Jarang ada } \\
\text { - PT Dipantara } \\
\text { Yogyakarta pernah } \\
\text { menyampaikan } \\
\text { perhitungan kubikasi } \\
\text { kayu, harga kayu }\end{array}$ & $\begin{array}{l}\text { Pemasaran Madu (oleh } \\
\text { Jaringan Madu Hutan } \\
\text { Sumbawa) }\end{array}$ & $\begin{array}{l}\text { - Pemasaran madu } \\
\text { (oleh WWF di } \\
\text { Fatumnasi) }\end{array}$ \\
\hline $\begin{array}{l}\text { Kebijakan Kayu } \\
\text { dan HHBK }\end{array}$ & $\begin{array}{l}\text { - Surat Keterangan Asal } \\
\text { Usul (SKAU) Kayu } \\
\text { - Sistem verifikasi legalitas } \\
\text { kayu }\end{array}$ & - Belum ada & $\begin{array}{l}\text { - SKAU } \\
\text { - Larangan menebang } \\
\text { di hutan lindung }\end{array}$ \\
\hline
\end{tabular}

Sumber: Hasil studi berdasarkan wawancara dan FGD dengan petani.

Berdasarkan informasi dari petani, materi penyuluhan yang jarang disampaikan oleh penyuluh pemerintah adalah tentang pemasaran dan kebijakan kayu/hasil hutan bukan kayu. Menurut 
koordinator penyuluh BP3K Kecamatan Karangmojo Kabupaten Gunungkidul, materi pemasaran kayu dan hasil hutan bukan kayu biasanya dilakukan oleh Dinas Perindustrian dan Perdagangan. Selama ini koordinasi antara Dinas Perindustrian dan Perdagangan Gunungkidul dengan Badan Pelaksana Penyuluhan dan Ketahanan Pangan Kabupaten Gunungkidul belum terjalin. Dalam FGD dengan petani di Desa Bejiharjo diperoleh informasi bahwa di kalangan petani informasi tentang pemasaran kayu pernah diperoleh dari lembaga swasta seperti PT Dipantara Yogyakarta dan Perkumpulan ARUPA yang melakukan pendampingan kepada petani hutan rakyat dan pernah menyampaikan tentang penghitungan kubikasi kayu dan harga kayu.

Materi penyuluhan tentang kebijakan kayu dan hasil hutan bukan kayu sampai saat ini belum pernah disampaikan oleh tenaga penyuluh dari BP3K Kecamatan Karangmojo dan BP3K Kecamatan Paliyan. Menurut petani di Desa Karangasem Kecamatan Paliyan dalam dua tahun terakhir mereka pernah memperoleh informasi tentang kebijakan kehutanan mengenai ijin tebang, Surat Keterangan Asal Usul (SKAU) kayu, serta sistem verifikasi legalitas kayu (SVLK). Materi tersebut petani peroleh dari Dinas Kehutanan dan Perkebunan Kabupaten Gunungkidul, Perkumpulan ARUPA dan Perhimpunan Shorea.

Di Kabupaten Sumbawa, materi pemasaran belum pernah disampaikan oleh penyuluh pemerintah. Menurut petani, pemasaran kayu dan hasil hutan bukan kayu adalah hal yang perlu diketahui. Saat ini informasi dan pengetahuan tentang pemasaran lebih terbatas dibandingkan dengan pengetahuan tentang produksi dan teknik budidaya. Materi kebijakan tentang kayu dan hasil hutan bukan kayu belum pernah disampaikan oleh penyuluh kehutanan BP4K Sumbawa. Sebagian besar peserta yang mengikuti diskusi kelompok di Desa Batudulang belum mengetahui tentang kebijakan yang berhubungan dengan kayu dan hasil hutan bukan kayu.

Di Kabupaten Sumbawa ada dua landasan hukum yang digunakan sebagai pijakan dalam kebijakan kayu yaitu: Perda No. 26 tahun 2006 tentang Ijin Pemanfaatan Kayu Tanah Milik (IPKTM) dan Peraturan Menteri Kehutanan No. 30 tahun 2012 tentang Penatausahaan Hasil Hutan Dari Hutan Hak. Menurut Nurdin Hamid (laki-laki) yang mengetahui tentang kebijakan dari mengikuti seminar dan lokakarya yang dilakukan oleh WWF Indonesia dan CIFOR menyatakan bahwa Perda No. 26/2006 tentang IPKTM lebih menguntungkan pengusaha. Peraturan Menteri Kehutanan No. 30/2012 menurut beliau belum terlaksana di desa-desa di Kabupaten Sumbawa. Hal tersebut disebabkan sebagian besar petani belum memiliki sertifikat tanah, yang menjadi salah satu syarat dalam pembuatan Surat Keterangan Asal Asul (SKAU). Pejabat penerbit SKAU juga belum ada di setiap desa, dimana hal tersebut menyebabkan terjadinya manipulasi dan penyelewengan penggunaan SKAU yang disebut dengan "SKAU terbang".

Di Kabupaten Timor Tengah Selatan, penyuluh pemerintah belum pernah menyampaikan materi penyuluhan tentang pemasaran kayu dan hasil hutan bukan kayu. Materi penyuluhan tentang pemasaran madu pernah disampaikan oleh WWF Indonesia di Desa Fatumnasi. Penyampaian materi 
pemasaran madu dilakukan dengan mendampingi kelompok masyarakat yang memanfaatkan madu alam di Gunung Mutis. Materi kebijakan kayu dan hasil hutan bukan kayu yang pernah disampaikan oleh penyuluh kehutanan di Kabupaten Timor Tengah Selatan adalah tentang SKAU oleh Dinas Kehutanan Kabupaten Timor Tengah Selatan. Penyuluhan tentang pemanfaatan hasil hutan bukan kayu di hutan lindung Gunung Mutis pernah dilakukan oleh Balai Konservasi Sumber Daya Alam (BKSDA) setempat.

\subsubsection{Metode Penyuluhan}

Dalam penyuluhan, agar materi dapat diterima oleh petani atau pelaku utama lainnya maka diperlukan metode atau cara penyampaian yang sesuai. Metode penyuluhan yang paling sering digunakan di ketiga kabupaten adalah diskusi dan praktik, sedangkan metode kunjungan lapang masih kurang digunakan (Gambar 8.)

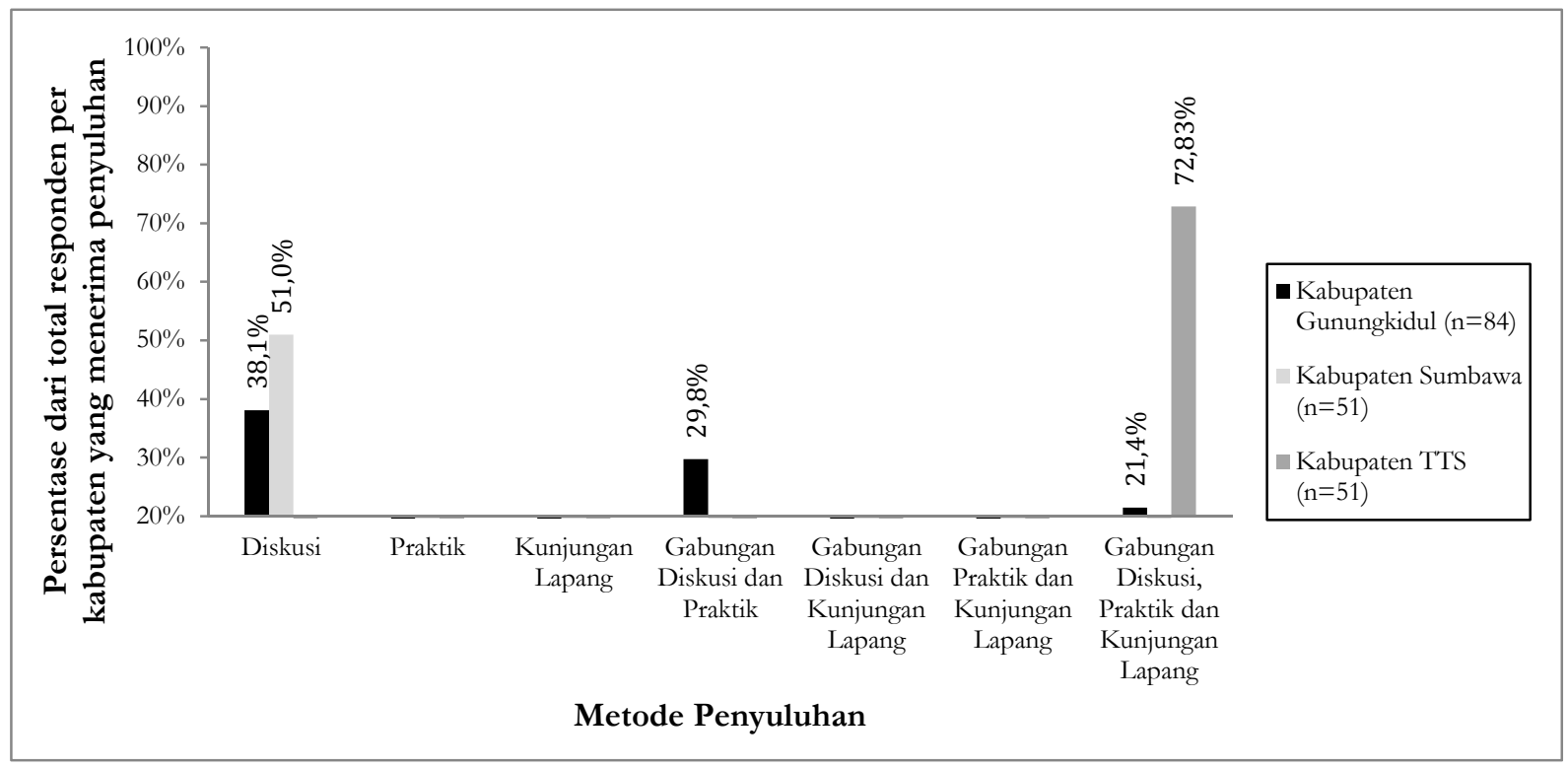

Sumber: Hasil survei rumahtangga berdasarkan wawancara dengan petani

Gambar 8. Metode penyuluhan yang digunakan pada Kabupaten Gunungkidul, Kabupaten Sumbawa dan Kabupaten Timor Tengah Selatan.

Metode penyuluhan yang sering dilakukan oleh tenaga penyuluh dalam menyampaikan materi cukup beragam di Kabupaten Gunungkidul. Dari FGD dan wawancara mendalam dengan penyuluh metode yang teridentifikasi pernah dilakukan yaitu: ceramah, diskusi, simulasi, demonstrasi plot, sekolah lapang (SL), praktik lapangan dan studi banding. Hal tersebut sesuai dengan metode yang sering muncul dalam program penyuluhan kehutanan kabupaten Gunungkidul yaitu ceramah dan diskusi. Metode ceramah dan diskusi biasanya digunakan untuk menyampaikan sebuah informasi guna meningkatkan pengetahuan petani. Sedangkan metode praktik digunakan untuk memperdalam pengetahuan dan meningkatkan keterampilan petani. 
Pendampingan kelompok bibit rakyat merupakan metode penyuluhan yang sering digunakan oleh penyuluh kehutanan di Kabupaten Sumbawa. Dalam menyampaikan materi biasanya penyuluh melakukan ceramah dan dilanjut dengan melakukan praktik. Menurut peserta diskusi kelompok di Desa Batudulang penyuluh lebih sering menyampaikan teori dengan ceramah ketika melakukan penyuluhan. Kegiatan praktik kadang disampaikan meski tidak sering. Petani lebih senang jika penyuluhan dilakukan dengan penyampaian teori dan praktik. Menurut Nurdin Hamid persentase penyampaian teori dan praktik yang menurut beliau pas adalah seimbang.

Metode penyuluhan yang telah dilakukan oleh penyuluh di Kabupaten Timor Tengah Selatan dalam menyampaikan materi ada beberapa seperti: diskusi, ceramah, sekolah lapang, demontrasi plot, kebun contoh, dan demonstrasi cara. Penyuluh pemerintah lebih sering menggunakan metode diskusi, ceramah, sekolah lapang dan demontrasi plot. Penyuluh-fasilitator dari lembaga penyuluh swasta lebih sering menggunakan metode yang melibatkan partisipasi peserta, seperti permainan, kebun percontohan, demonstrasi cara dan diskusi kelompok.

\subsubsection{Media Penyuluhan}

Bentuk media penyuluhan yang paling sering digunakan dalam kegiatan penyuluhan di Kabupaten Gunungkidul, Kabupaten Sumbawa dan Kabupaten Timor Tengah Selatan adalah buku (Gambar 9.). Buku paling sering digunakan di Kabupaten Sumbawa $(82,4 \%)$ dan leaflet paling sering digunakan di Kabupaten Gunungkidul (12,0\%) (Gambar 9).

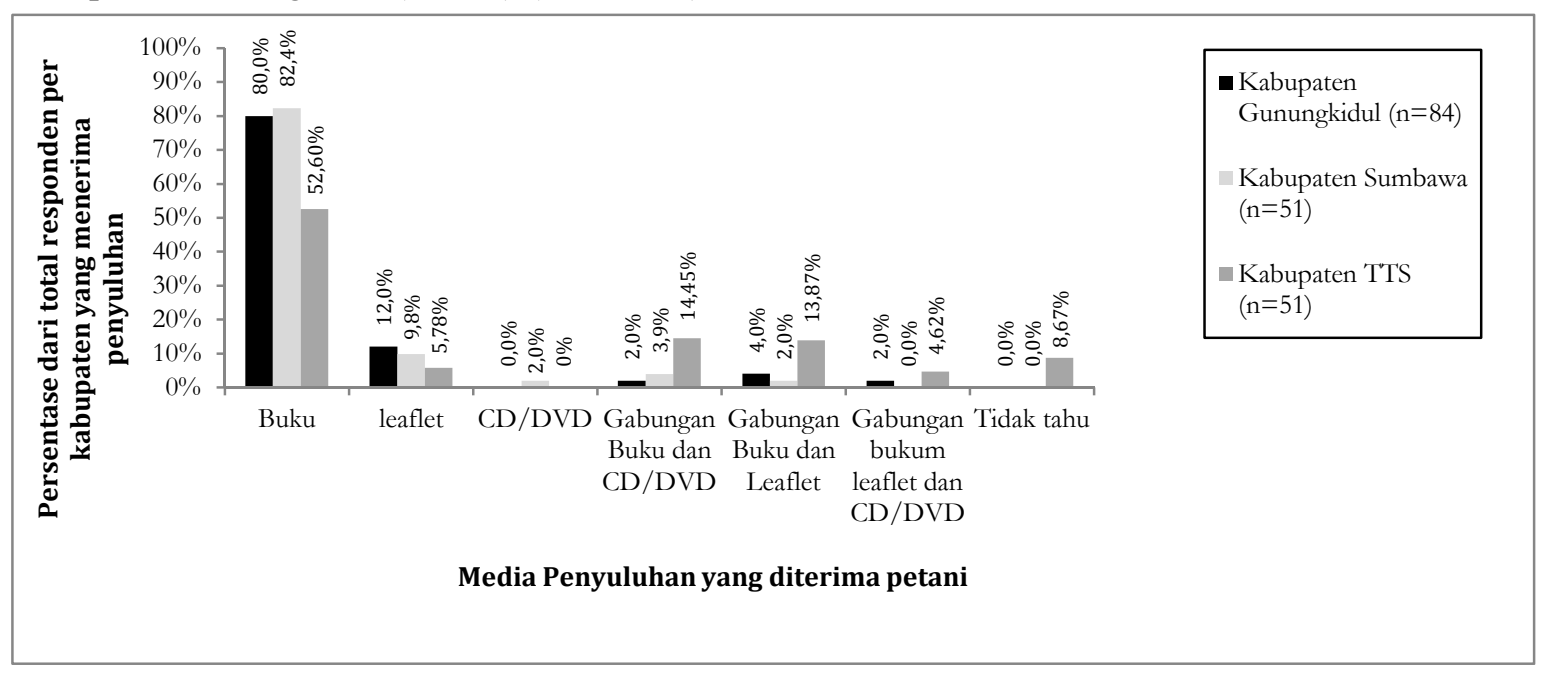

Sumber: Hasil survei berdasarkan wawancara dengan petani

Gambar 9. Bentuk media penyuluhan yang digunakan dalam kegiatan penyuluhan di Kabupaten Gunungkidul, Kabupaten Sumbawa dan Kabupaten Timor Tengah Selatan

Berdasarkan hasil diskusi kelompok dan wawancara dengan tenaga penyuluh di BK3P Kecamatan Karangmojo dan Kecamatan Paliyan, Kabupaten Gunungkidul bahwa media penyuluhan yang sering digunakan adalah buku panduan dan leaflet. BP2KP Kabupaten Gunungkidul dalam lima tahun 
terakhir ini telah memproduksi materi penyuluhan berupa leaflet. Leaflet yang diproduksi sebagaian besar tentang isu-isu ketahanan pangan seperti: pangan lokal, sumber pangan alternatif. Sedangkan media penyuluhan pertanian yang diproduksi oleh BP2KP adalah leaflet tentang budidaya kedelai. BP2KP kabupaten Gunungkidul, BP3K Karangmojo dan BP3K Paliyan saat ini belum memproduksi materi penyuluhan tentang kehutanan.

Penyuluh di Karangmojo dan Paliyan selama ini menggunakan media penyuluhan yang diproduksi oleh BP2KP Kabupaten Gunungkidul dan media-media penyuluhan yang diproduksi oleh lembaga lain seperti: Badan Ketahanan Pangan dan Penyuluhan Daerah Istimewa Yogyakarta; Balai Pengkajian Teknologi Pertanian Yogyakarta.

BP3K Kecamatan Karangmojo pada tahun 2014 mencetak leaflet tentang Cara Tanam Jajar Legowo Padi Lahan Sawah. Materi leaflet tersebut disusun oleh tenaga penyuluh pertanian BP3K Kecamatan Karangmojo yang kemudian akan dilakukan editing oleh koordinator penyuluh sebelum dicetak. Distribusi leaflet dilakukan ke kelompok tani dampingan di Kecamatan Karangmojo. Pendistribusian akan dilakukan secepatnya sampai dengan satu tahun setelah cetak.

Dalam FGD yang dilakukan di Desa Karangduwet dan Bejiharjo, petani menilai bahwa leaflet yang dibuat dan gunakan oleh penyuluh selama ini kurang efektif. Sedikitnya gambar dan banyaknya tulisan yang berukuran kecil menjadikan petani enggan untuk membacanya. Menurut petani media yang menarik adalah media yang lebih banyak gambar dan tulisan singkat.

Selain media cetak BP2KP Gunungkidul juga menggunakan media audio berupa siaran feature dan talkshow radio. Sayangnya ketika diklarifikasi dalam kegiatan FGD sebagian besar petani sudah jarang mengakses radio. Ada satu petani di Desa Bejiharjo yang masih mengakses radio untuk mendengarkan informasi tentang pertanian. Petani lebih senang mengakses media televisi dari pada radio. Media yang cukup diminati oleh petani adalah audio visual. Perkumpulan ARUPA memproduksi film tutorial "Menghitung Karbon Hutan Rakyat" dan PT. Rimba Partikel Indonesia juga menggunakan media slideshow dan film dalam menyampaikan informasi tentang Suaka Margasatwa Paliyan dan profil perusahaannya.

Hingga saat ini penyuluh kehutanan BP4K Kabupaten Sumbawa belum pernah memproduksi media penyuluhan. Mereka menggunakan media penyuluhan yang berupa brosur dari Badan Koordinasi Penyuluhan Provinsi Nusa Tengggara Barat. Penyuluh mengambil materi dan informasi untuk penyuluhan dari buletin kehutanan, majalah dan buku saku. Sebagian besar penyuluh kehutanan di Kabupaten Sumbawa masih kurang mampu mengakses internet dan mengoperasikan komputer.

Badan Ketahanan Pangan dan Penyuluhan Kabupaten Timor Tengah Selatan sejak tahun 2012 belum pernah memproduksi media untuk penyuluhan. Selama ini penyuluh menggunakan media yang dicetak pada sebelum tahun 2012. Beberapa leaflet yang digunakan penyuluh di Kecamatan Mollo 
Utara adalah leaflet yang diproduksi oleh Sekretariat Penyuluhan Pertanian Dinas Pertanian dan Ketahanan Pangan Kabupaten Timor Tengah Selatan Tahun 2011. BPK Mollo Utara pernah mencetak leaflet tentang panduan budidaya wortel dan kentang pada tahun 2006, dan masih digunakan hingga saat ini.

Media penyuluhan kehutanan belum pernah diproduksi oleh BKP2 Kabupaten Timor Tengah Selatan. Selama ini penyuluh kehutanan menggunakan materi dari lembaga lain seperti leaflet dari Dinas Kehutanan dan Perkebunan Kabupaten Timor-Tengah Selatan dan Kementerian Kehutanan. Menurut Mariah Elisabeth Magang, materi untuk media penyuluhan sebenarnya sudah ada, namun anggaran untuk mencetaknya yang tidak ada. Untuk menyisatinya penyuluh akan memfotokopi materi yang mereka buat di atas kertas berwarna. Leaflet tersebut akan mereka bagikan kepada petani. Dalam setahun penyuluh menyusun 2-3 materi untuk penyuluhan.

Helen Keller International-Indonesia (HKI-Indonesia) menggunakan beberapa media dalam kegiatan edukasinya tentang kesehatan dan nutrisi. Media yang mereka cetak antara lain: kartu makanan, permaianan ulartangga, poster, buku menu masakan bergizi, factsheet, dan kalender tanaman sayuran untuk kebun percontohan. Media yang dicetak oleh HKI-Indonesia penuh warna, mudah dilihat dan lebih banyak gambar dari pada tulisan. Menurut Koordinator Proyek HKI-Indonesia pembuatan media diawali dengan melakukan survei bersama dengan masyarakat yang akan menerima manfaat. Seperti pemilihan warna, simbol tradisional, dan materi informasi dalam kalender tanaman sayuran dilakukan dengan proses diskusi bersama masyarakat.

Menurut petani media yang mudah mereka terima adalah media yang dapat mereka dengar, media yang dapat dilihat seperti gambar dan film. Sebagian besar petani yang menjadi peserta FGD di Desa Bosen dan Desa Fatumnasi sudah sangat jarang mendengarkan radio, mereka lebih sering melihat televisi. Ada satu stasiun radio di Soe yang menyiarkan acara pertanian yaitu Radio Pemerintah Daerah Timor Tengah Selatan di Soe, namun pendengarnya terbatas. Kebiasaan petani di kedua desa tersebut akan menempelkan poster atau informasi bergambar lainnya di rumah ketika mereka mendapatkannya.

\subsubsection{Sumber informasi bagi petani yang tidak menerima penyuluhan}

Petani yang tidak menerima penyuluhan, mengakses informasi tentang pertanian dan kehutanan secara turun-temurun dan dari teman/tetangga (Gambar 10). Seseorang memperoleh informasi pertama kali cenderung dari orang terdekat mereka. Keluarga atau orang yang dalam ikatan keturunan adalah sumber informasi pertama sebelum seseorang menerima informasi dari pihak lain/luar. Di Kabupaten yang berada di luar Pulau Jawa seperti Sumbawa dan Timor Tengah Selatan menunjukkan bahwa sumber informasi yang di terima petani berasal dari dua hal yaitu secara turuntemurun/keluarga dan teman/tetangga. Sedangkan di Kabupaten Gunungkidul yang berada di Pulau 
Jawa menunjukkan adanya sumber informasi lain yaitu media. Di sini terlihat bahwa pembangunan sarana prasarana juga berpengaruh pada petani dalam mengakses sumber informasi.

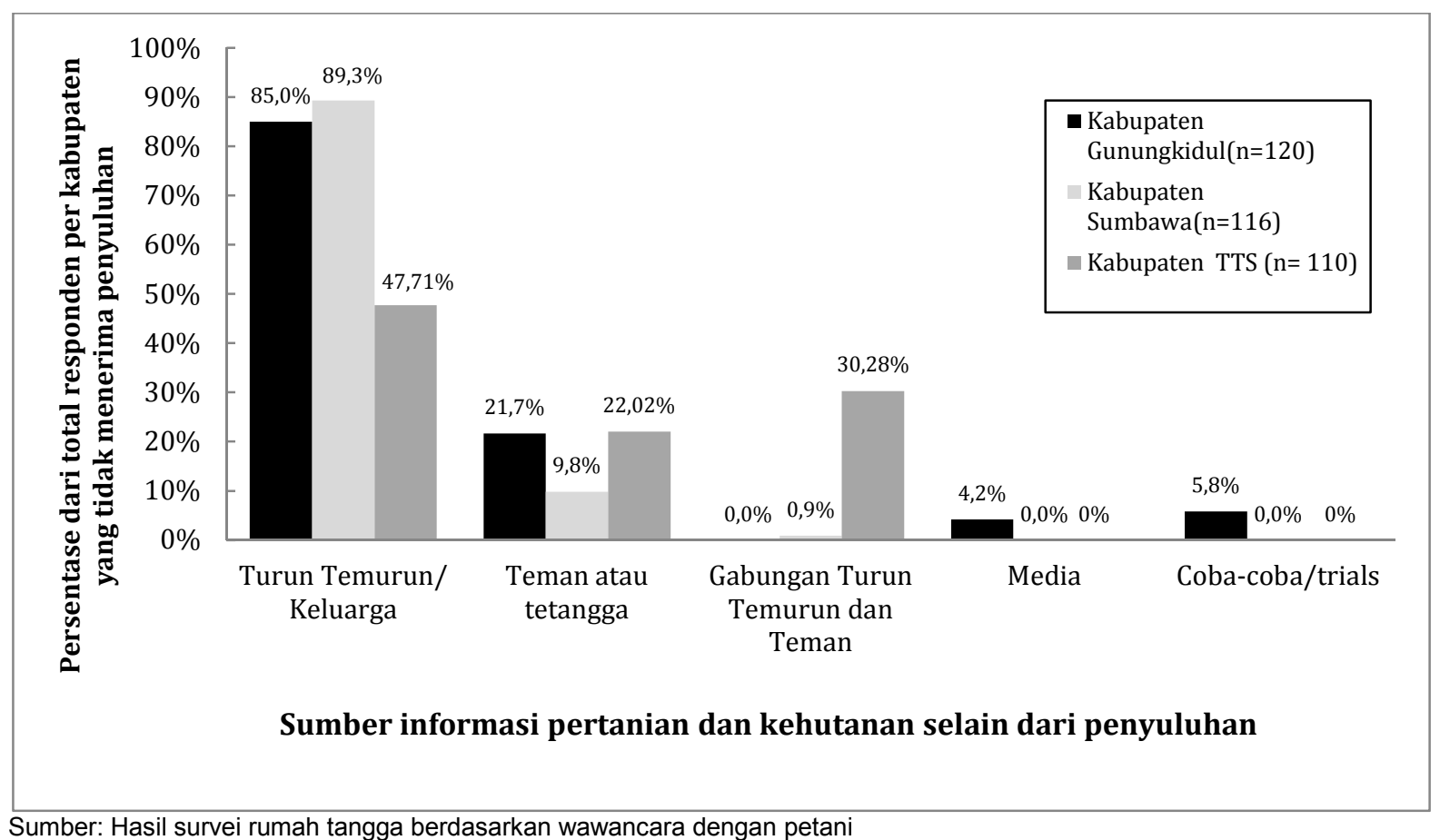

Gambar 10. Sumber Informasi tentang pertanian dan kehutanan bagi petani yang tidak menerima penyuluhan.

\subsection{Kebijakan Anggaran Penyuluhan}

\subsubsection{Anggaran Penyuluhan Kabupaten Gunungkidul, Daerah Istimewa Yogyakarta}

Anggaran penyuluhan di Badan Pelaksana Penyuluhan dan Ketahanan Pangan (BP2KP) Kabupaten Gunungkidul berasal dari Anggaran Pendapatan dan Belanja Daerah (APBD) Kabupaten Gunungkidul; Dana Alokasi Khusus (DAK); dan Anggaran Pendapatan dan Belanja Negara (APBN). APBD Kabupaten Gunungkidul dialokasikan untuk program demontrasi plot (demplot) setiap tahunnya. APBN adalah dana baku yang dialokasikan untuk operasional penyuluhan seperti: pertemuan rutin kelompok tani, transportasi kegiatan penyuluhan dan lain-lain. DAK digunakan untuk fasilitas tenaga penyuluh seperti: membangun/merenovasi kantor Balai Penyuluhan Pertanian, Perikanan dan Kehutanan (BP3K), pengadaan kendaraan bermotor, pengadaan alat kerja (laptop/komputer), dan lain-lain.

Pengajuan APBD Kabupaten dilakukan setiap tahunnya melalui proses musrenbang di kabupaten, sedangkan APBN diajukan rutin setiap tahunnya dan bentuknya baku. DAK diajukan ketika 
pentunjuk teknis penggunaan sudah diterbitkan, pengajuan DAK ditujukan ke pemerintah pusat namun melalui Badan Koordinasi Penyuluhan Provinsi.

Anggaran penyuluhan BP3K berasal dari BP2KP Kabupaten Gunungkidul yang digunakan untuk operasional penyuluhan. Menurut Wagimin anggaran operasional penyuluhan sebesar Rp 112.000/penyuluh/bulan. Anggaran tersebut tidak dapat membiayai semua program penyuluhan selama setahun yang telah disusun. Besar anggaran tersebut hanya digunakan untuk memenuhi kebutuhan camilan dan minum pada pertemuan rutin kelompok. Guna menjalankan program penyuluhan, beberapa strategi dilakukan seperti: pendekatan melalui kelompok tani dan menghadiri ketika petani melakukan kegiatan.

\subsubsection{Anggaran Penyuluhan Kabupaten Sumbawa, Nusa Tenggara Barat}

Anggaran penyuluhan di Kabupaten Sumbawa saat ini berasal dari APBD Kabupaten, APBD Provinsi, dan APBN. Menurut Kepala Sub Bagian Program BP4K Bapak Iwan Setiawan, APBD Kabupaten yang dialokasikan untuk penyuluhan kehutanan kecil. APBN didistribusikan melalui Anggaran Dekonsentrasi, dimana dilakukan oleh Badan Koordinasi Penyuluhan Provinsi langsung ke penyuluh. Dana ini digunakan untuk biaya operasional penyuluhan dimana jumlahnya sebesar Rp 400.000/bulan/penyuluh.

APBD Kabupaten dialokasikan untuk kegiatan lapangan seperti demonstrasi plot, kebun bibit rakyat (KBR) dan sekolah lapang. Anggaran tersebut cenderung mengalami penurunan setiap tahunnya. Sebagai contoh pada tahun 2013 dianggarkan ada 70 KBR, dan pada tahun 2014 dianggarkan ada 30 KBR. Secara langsung penurunan anggaran juga mempengaruhi kegiatan penyuluhan di lapangan dan tidak semua program penyuluhan yang telah disusun dapat terealisasi.

Guna tetap menjalankan kegiatan penyuluhan yang telah diprogramkan beberapa penyuluh melakukan perubahan strategi seperti:

- Mengubah pendekatan kelompok menjadi pendekatan perorangan.

- Melakukan integrasi dengan program-program terkait lainnya.

- Melakukan penyuluhan ke sekolah dengan bekerjasama dengan Dinas Pendidikan.

Issue anggaran lain yang menjadi catatan dari para penyuluh adalah kurangnya anggaran untuk peningkatan kapasitas penyuluh. Penyuluh mengharapkan adanya peningkatan anggaran untuk peningkatan kapasitas penyuluh, seperti pelatihan, seminar, atau bentuk yang lainnya. 


\subsubsection{Anggaran Penyuluhan Kabupaten Timor Tengah Selatan, Nusa Tenggara Timur}

Anggaran penyuluhan di Badan Ketahanan Pangan dan Penyuluhan (BKP2) Kabupaten Timor Tengah Selatan berasal dari APBN yang berupa Biaya Operasional Penyuluhan (BOP); APBD Kabupaten Timor Tengah Selatan; Dana Alokasi Khusus (DAK). BOP dialokasikan untuk sarana produksi (bibit, pupuk), transportasi penyuluh, dan materi penyuluhan. BOP turun setiap 3 bulan per terminnya ke BKP2 Kabupaten Timor Tengah Selatan. BOP ini akan diturunkan ke Balai Penyuluhan Kecamatan (BPK) sebesar Rp 500.000/bulan/penyuluh. Selain dari BOP ada anggaran dari APBD dan APBN yang dialokasikan untuk kegiatan Sekolah Lapang. Menurut Mariah Elisabeth Magang (perempuan, 43th) koordinator penyuluh kehutanan Kabupaten Timor Tengah Selatan, anggaran penyuluhan dari APBD Kabupaten untuk sub sektor kehutanan yang lolos sangat minim bahkan tidak ada. Hal tersebut dikarenakan program yang diajukan sering bukan menjadi prioritas pembangunan. DAK dialokasikan untuk fasilitas penyuluh seperti: membangun/merenovasi kantor BPK, pengadaan kendaraan bermotor, pengadaan alat kerja/laptop/komputer, dan lain-lain.

Pengajuan APBD Kabupaten diajukan setiap tahunnya melalui proses musrenbang di kabupaten, dan internal BKP2. Setiap bidang di BKP2 akan mengajukan Rencana Anggaran Keuangan (RAK) ke bagian program. BKP2 kemudian akan mengajukan RAK dan mempresentasikannya dalam pembahasan anggaran di Badan Perencanaan Daerah, dan akan diajukan ke Dewan Perwakilan Rakyat Daerah. BOP dari APBN diajukan rutin setiap tahunnya dan bentuknya baku. DAK diajukan ketika pentunjuk teknis penggunaan sudah diterbitkan, pengajuan DAK ditujukan ke pemerintah pusat namun melalui Badan Koordinasi Penyuluhan Provinsi.

Dari anggaran yang ada, tidak mencukupi untuk membiayai semua program penyuluhan yang telah disusun. Oleh karena itu, guna menjalankan program penyuluhan beberapa strategi dilakukan seperti: mengatur wilayah tugas penyuluh, menggunakan dana swadaya, dan pemadatan waktu kegiatan.

\subsection{Kebutuhan dan Tantangan Penyuluhan Kehutanan dan Agroforestri}

Penyuluhan merupakan salah satu proses pendidikan bagi petani dimana sebagian besar penduduk Indonesia menggantungkan hidupnya dari pertanian, perikanan dan kehutanan. Kedepannya, penyuluhan khususnya di sektor kehutanan dan agroforestri memiliki kebutuhan yang besar. Jika melihat dari hasil temuan di ketiga kabupaten lokasi studi ada beberapa hal yang menjadi kebutuhan dan tantangan di penyuluhan kehutanan yaitu:

a. Jumlah dan kualitas tenaga penyuluh kehutanan dari pemerintah untuk memberikan layanan penyuluhan. Jumlah penyuluh kehutanan saat ini rata-rata satu penyuluh dengan wilayah kerja satu kecamatan. Usia penyuluh kehutanan saat ini sebagian besar usianya di atas 50 tahun (Gunungkidul 100\%; Sumbawa 77,3\%; TTS 37,5\%), dimana dalam lima tahun ke depan akan memasuki masa pensiun. Jumlah penyuluh kehutanan pada tahun 2014 sebanyak 5.056 orang yang harus menjalankan tugas di 5.340 kecamatan yang ada di Indonesia. 
Sedangkan kebutuhan penyuluh kehutanan untuk melaksanakan penyuluhan di wilayah Indonesia sebanyak 20.241 orang.

b. Kurangnya materi penyuluhan kehutanan yang disampaikan kepada petani. Materi penyuluhan yang disampaikan kepada petani pada saat ini masih terbatas pada teknik budidaya, pembibitan (kebun bibit rakyat) dan konservasi. Materi penyuluhan yang berhubungan dengan hasil kebun dan hutan yang potensial seperti kayu dan hasil hutan bukan kayu masih sangat kurang. Materi tentang pemasaran produk kehutanan (kayu dan hasil hutan bukan kayu) dan kebijakan yang mendukung di ketiga kabupaten masih kurang bahkan tidak ada.

c. Terbatasnya anggaran untuk penyuluhan kehutanan yang dapat mempengaruhi kualitas kegiatan penyuluhan yang dilakukan. Hal ini dapat berpengaruh pada pelaksanaan program penyuluhan yang telah disusun seperti: intensitas penyuluhan, pengadaan media, penentuan metode, sarana prasarana dan keberlanjutan penyuluhan.

Berdasarakan kondisi yang ada saat ini, terdapat beberapa potensi yang dapat dikembangkan guna kerja penyuluhan kehutanan yang lebih baik, yaitu:

a. Adanya lembaga penyuluhan swasta dan swadaya -perusahaan dan lembaga swadaya masyarakat- yang telah melakukan penyuluhan dan pendampingan kepada petani. Kerjasama dengan lembaga penyuluhan swasta dan swadaya akan meningkatkan kuantitas dan kualitas penyuluhan kehutanan sehingga bisa menjangkau wilayah yang terpencil/jauh dari pusat pemerintahan.

b. Meningkatkan kolaborasi kerja antara penyuluh kehutanan, penyuluh pertanian dan penyuluh perikanan di dalam konteks penyuluhan agroforestri.

c. Meningkatkan jumlah dan peran dari Penyuluh Kehutanan Swadaya Masyarakat (PKSM) dalam membantu layanan penyuluhan kehutanan guna jangkauan yang lebih luas.

d. Hasil penelitian yang dipublikasikan oleh Balai Penelitian dan Pengembangan Kehutanan Kementerian Lingkungan Hidup dan Kehutanan dan lembaga penelitian lainnya dapat dijadikan sebagai materi penyuluhan yang disampaikan ke petani. Selama ini hasil penelitian belum optimal disampaikan kepada Badan Pelaksana Penyuluhan. Hasil penelitian selama ini cenderung disampaikan kepada Dinas Kehutanan dan Perkebunan di Kabupaten/Kota. 


\section{Kesimpulan dan Saran}

Pelaksanaan Penyuluhan Pertanian di Indonesia telah dilakukan sejak tahun 1905 dimana terus mengalami perubahan dan perkembangan bersamaan dengan perubahan politik dan pemerintahan. Sistem penyuluhan terbaru di Indonesia ditandai dengan diterbitkannya Undang-Undang No. 16/2006 yang mengatur tentang Sistem Penyuluhan Pertanian, Perikanan dan Kehutanan di Indonesia. Penyuluhan Pertanian, Perikanan dan Kehutanan di Indonesia pada era UU. No 16/2006 dilaksanakan oleh Badan Pelaksana Penyuluhan.

Analisa studi ini menunjukkan bahwa masih banyak petani di lokasi studi yang belum mendapatkan layanan penyuluhan tentang kehutanan dan agroforestri yang cukup. Hal tersebut menunjukkan belum optimalnya sistem penyuluhan kehutanan dan agroforestri. Tantangan-tantangan berikut diantaranya yang menghambat kurang optimalnya sistem penyuluhan kehutanan dan agroforestri: jumlah dan kualitas tenaga penyuluh kehutanan dari pemerintah untuk memberikan layanan penyuluhan; kurangnya materi penyuluhan kehutanan yang disampaikan kepada petani; terbatasnya anggaran untuk penyuluhan kehutanan yang dapat mempengaruhi kualitas kegiatan penyuluhan.

Adapun potensi yang dapat dikembangkan untuk meningkatkan layanan dan kinerja penyuluhan yaitu: (a) Kerjasama dengan lembaga penyuluhan swasta dan swadaya guna meningkatkan kuantitas dan kualitas penyuluhan kehutanan; (b) Kolaborasi kerja antara penyuluh kehutanan, pertanian dan perikanan di dalam konteks penyuluhan agroforestri; (c) Penyuluh Kehutanan Swadaya Masyarakat (PKSM) dalam membantu layanan penyuluhan kehutanan yang lebih luas; dan (d) Hasil penelitian yang dipublikasikan oleh Balai Penelitian dan Pengembangan Kehutanan Kementerian Lingkungan Hidup dan Kehutanan dan lembaga penelitian lainnya sebagai materi penyuluhan.

Untuk meningkatkan efektifitas pelaksanaan penyuluhan di tingkat kabupaten, perlu ada kolaborasi antara Badan Pelaksana Penyuluhan dengan lembaga penyuluhan swasta dan swadaya, sehingga dapat memperluas wilayah jangkauan penyuluhan. Kerjasama dengan badan-badan penelitian juga perlu diperkuat, sehingga dapat memperkaya dan memperbaharui materi penyuluhan kehutanan yang dapat disampaikan kepada petani. 


\section{Daftar Pustaka}

Ahmad, S. 29 Oktober 2011. Sejarah Penyuluhan Pertanian di Indonesia. http://ahmadsyufri.blogspot.com/2011/10/sejarah-penyuluhan-pertanian-di.html. 27 Juli 2015.

Badan Pusat Statistik (BPS) Kabupaten Gunungkidul, 2012. Kabupaten Gunungkidul Dalam Angka 2012. Kabupaten Gunungkidul, Daerah Istimewa Yogyakarta: BPS Kabupaten Gunungkidul.

Badan Pusat Statistik (BPS) Kabupaten Gunungkidul, 2014. Kabupaten Gunungkidul Dalam Angka 2014. Kabupaten Gunungkidul, Daerah Istimewa Yogyakarta: BPS Kabupaten Gunungkidul.

BPS Kabupaten Sumbawa, 2013. Kabupaten Sumbawa Dalam Angka 2013. Kabupaten Sumbawa, Provinsi Nusa Tenggara Barat: BPS Kabupaten Sumbawa.

BPS Kabupaten Sumbawa, 2013. Kecamatan Batulanteh Dalam Angka 2013. Kabupaten Sumbawa, Provinsi Nusa Tenggara Barat: BPS Kabupaten Sumbawa.

BPS Kabupaten Sumbawa, 2013. Kecamatan Unter Iwes Dalam Angka 2013. Kabupaten Sumbawa, Provinsi Nusa Tenggara Barat: BPS Kabupaten Sumbawa.

BPS Kabupaten Timor Tengah Selatan, 2014. Kabupaten Timor Tengah Selatan Dalam Angka 2014. Kabupaten Timor Tengah Selatan, Provinsi Nusa Tenggara Timur: BPS Kabupaten Timor Tengah Selatan.

Kesatuan Pengelolaan Hutan, 2012. Profil KPHP Model Batulanteh Provinsi Nusa Tenggara Barathttp://www.kph.dephut.go.id/index.php?option=com_content\&view=article\&id=92\&Itemid= 354. 6 Agustus 2015.

Nimwegen P, Lloyd D, Vanclay J, Murphy M, Canning N, Sare Julia, Ffoulkes David, Butarbutar T, Budisantoso E. 2009. Laporan Akhir: Prospek agroforestri kayu makanan ternak-hewan ternak terintegrasi bagi diversifikasi ekonomi di masyarakat pertanian Timor Barat-Laporan Penelitian SADI-ACIAR. Camberra Australia: Australia Centre for International Agriculture Research.

Pemerintah Daerah Sumbawa, 2015. Keputusan Bupati Sumbawa No 4012015 Tentang Penetapan Wilayah Kerja Penyuluh Pertanian, Perikanan dan Kehutanan Di Lingkungan Pemerintah Kabupaten Sumbawa. Sekretariat Daerah Sumbawa. Sumbawa.

Pemerintah Kabupaten Timor Tengah Selatan, 2012. Keputusan Bupati Timor Tengah Selatan Nomor: BKD.820/107/2012 Tentang Penempatan Penyuluh Pada Wilayah Kerja Di Kabupaten Timor Tengah Selatan. Sekretariat Daerah Timor Tengah Selatan. Timor Tengah Selatan.

Pemerintah Kabupaten Gunungkidul, 2014. Keputusan Kepala Badan Pelaksanan Penyuluhan dan Ketahanan Pangan No 36/KPTS/2014 Tentang Alih Tugas Pertanian/Perkebunan, Perikanan dan Kehutanan.: BP2KP Kabupaten Gunungkidul. Gunungkidul.

Pemerintah Kabupaten Gunungkidul, 2011. Peraturan Daerah Kabupaten Gunungkidul No 6 Tahun 2011 Tentang Rencana Tata Ruang Wilayah (RTRW) Kabupaten Gunungkidul 2010-2030. Lembar Daerah Kabupaten Gunungkidul Tahun 2011 No 3 Seri E, Sekretariat Daerah Kabupaten Gunungkidul. Gunungkidul.

Rebuplik Indonesia, 2006. Undang-Undang No 16 Tahun 2006 Tentang Sistem Penyuluhan Pertanian, Perikanan dan Kehutanan. Lembar Negara Republik Indonesia Tahun 2006 Nomor 92. Sekretariat Negara Republik Indonesia. Jakarta 
Rebuplik Indonesia, 2014. Peraturan Presiden Republik Indonesia No 154 Tahun 2014 Tentang Kelembagaan Penyuluhan Pertanian, Perikanan dan Kehutanan. Lembar Negara Republik Indonesia Tahun 2014 Nomor 311. Sekretariat Kabinet Republik Indonesia. Jakarta.

Tim Kanoppi CIFOR-ICRAF, 2014. Data Baseline Rumah Tangga Kanoppi tahun 2013

(Gunungkidul, Sumbawa dan Timor Tengah Selatan), Research Project on 'Development of timber and non-timber forest products' production and market strategies for improvement of smallholders' livelihoods in Indonesia (ACIAR FST/2012/039)', Tim Kanoppi (Kayu dan NonKayu dalam Sistem Produksi dan Pemasaran yang Terintegrasi), CIFOR (Center for International Forestry Research), \& ICRAF (the World Agroforestry Center), Bogor.

Rohadi D, Roshetko JM, Perdana A, Blyth M, Nurhayanto N, Kusumowardhani N, Pramono AA, Widyani N, Fauzi A, Sasono A, Sumardamto P, Manalu P, 2012. Final Report: Improving economic outcomes for smallholders growing teak agroforestry sustems in Indonesia. Camberra Australia: Australia Centre for International Agriculture Research.

Roshetko JM, D Rohadi, A Perdana, G Sabastian, N Nuryartono, AA Pramono, N Widyani, P Manalu, MA Fauzi, P Sumardamto, N Kusumowardhani. 2013. Teak agroforestry systems for livelihood enhancement, industrial timber production, and environmental rehabilitation. Forests, Trees, and Livelihoods 22 (4): 241-256 DOI: 10.1080/14728028.2013.855150 


\section{Lampiran 1. Keadaan wilayah, tujuan penyuluhan, materi dan metode pada program penyuluhan di Kabupaten Gunungkidul tahun}

2014.

\begin{tabular}{|c|c|c|c|c|}
\hline No & Keadaan wilayah & Tujuan Penyuluhan & Materi & Metode \\
\hline & Aspek Teknis Budidaya tanaman kehutanan & & & \\
\hline \multirow[t]{4}{*}{1} & \multirow[t]{4}{*}{$\begin{array}{l}\text { Kualitas hasil kayu Hutan Rakyat (HR) belum } \\
\text { optimal. }\end{array}$} & $\begin{array}{l}\text { Agar } 52 \% \text { petani HR mampu melakukan } \\
\text { pemupukan secara individu sesuai } \\
\text { Standar Operasional Prosedur (SOP) } \\
\text { budidaya HR yang baik }\end{array}$ & $\begin{array}{l}\text { Pemupukan tanaman secara } \\
\text { individu setiap tanaman hutan } \\
\text { rakyat }\end{array}$ & Ceramah, diskusi, demonstrasi \\
\hline & & $\begin{array}{l}\text { Agar } 50 \% \text { petani HR mengetahui cara } \\
\text { melakukan pruning jati dengan SOP } \\
\text { budidaya HR yang baik }\end{array}$ & $\begin{array}{l}\text { Teknik pruning tanaman jati pada } \\
\text { hutan rakyat }\end{array}$ & Ceramah, diskusi, kaji terap. \\
\hline & & $\begin{array}{l}\text { Agar } 48 \% \text { petani HR mengetahui cara } \\
\text { melakukan panen kayu pada umur } \\
\text { dewasa sesuai dengan SOP budidaya HR } \\
\text { yang baik }\end{array}$ & $\begin{array}{l}\text { Teknik pemanenan pohon dan } \\
\text { analisis ekonomi }\end{array}$ & Ceramah, diskusi, praktik. \\
\hline & & $\begin{array}{l}\text { Agar } 55 \% \text { petani HR mengetahui cara } \\
\text { memanfaatkan lahan bawah tegakan } \\
\text { untuk pertanaman yang produktif sesuai } \\
\text { dengan SOP budidaya HR yang baik. }\end{array}$ & $\begin{array}{l}\text { 1. Budidaya garut dan ganyong. } \\
\text { 2. Budidaya empon-empon (jahe, } \\
\text { kunir, lengkuas, dll). } \\
\text { 3. Budidaya tanaman Porang. }\end{array}$ & $\begin{array}{l}\text { Ceramah, diskusi, demonstrasi } \\
\text { percontohan, pelatihan }\end{array}$ \\
\hline \multirow[t]{2}{*}{2} & \multirow[t]{2}{*}{$\begin{array}{l}\text { Kualitas penghijauan sepadan pantai belum } \\
\text { optimal. }\end{array}$} & $\begin{array}{l}\text { Agar } 50 \% \text { petani pengelola penghijauan } \\
\text { pantai mengetahui cara menentukan dan } \\
\text { memilih jenis tanaman hutan sesuai } \\
\text { dengan SOP penghijauan pantai yang } \\
\text { baik. }\end{array}$ & $\begin{array}{l}\text { 1. Teknik memilih jenis tanaman } \\
\text { penghijauan pantai. } \\
\text { 2. Mengenali jenistanaman } \\
\text { kehutanan yang cocok untuk } \\
\text { penghijauan pantai. }\end{array}$ & $\begin{array}{l}\text { Ceramah, diskusi, demontrasi plot. } \\
\text { (demplot). }\end{array}$ \\
\hline & & $\begin{array}{l}\text { Agar } 55 \% \text { petani pengelola penghijauan } \\
\text { pantai mengetahui cara penghijauan } \\
\text { pantai sesuai dengan SOP. }\end{array}$ & $\begin{array}{l}\text { 1. Teknik pembuatan } \\
\text { penghijauan pantai } \\
\text { 2. Jarak tanam penghijauan } \\
\text { pantai } \\
\text { 3. Arah barisan tanaman. }\end{array}$ & Ceramah, diskusi, demplot, pelatihan \\
\hline
\end{tabular}




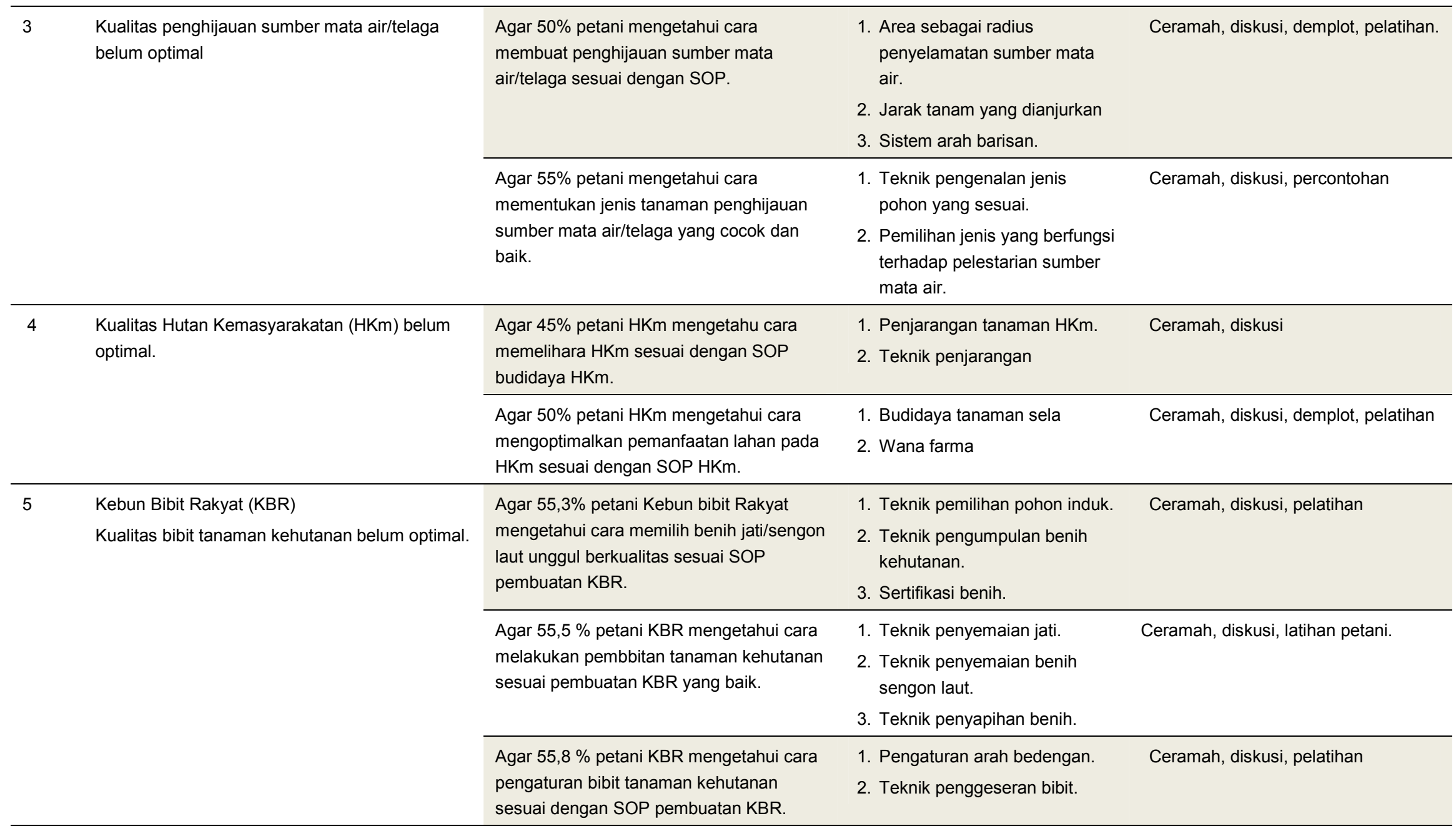




\begin{tabular}{|c|c|c|c|c|}
\hline No & Keadaan wilayah & Tujuan Penyuluhan & Materi & Metode \\
\hline & \multicolumn{4}{|l|}{ Aspek pengendalian aliran Permukaan } \\
\hline 1 & Bangunan terassering belum optimal & $\begin{array}{l}\text { 1. Agar } 50 \% \text { petani mengetahui cara } \\
\text { menanam tanaman penguat teras } \\
\text { yang baik. } \\
\text { 2. Agar } 55 \% \text { petani mengetahui cara } \\
\text { memelihara saluran teras sesuai } \\
\text { dengan SOP. }\end{array}$ & $\begin{array}{l}\text { 1. Mengenal tanaman penguat } \\
\text { teras. } \\
\text { 2. Pengaturan jarak tanaman } \\
\text { penguat teras. } \\
\text { 3. Teknik pemeliharaan saluran } \\
\text { teras. }\end{array}$ & Ceramah, diskusi, percontohan \\
\hline 2 & $\begin{array}{l}\text { Saluran Pembuangan Air (SPA) } \\
\text { Kualitas dan kuantitas saluran buangan air } \\
\text { masih sangat kurang }\end{array}$ & $\begin{array}{l}\text { 1. Agar } 55 \text { petani mengetahui cara } \\
\text { membuat Saluran Pembuangan Air } \\
\text { (SPA) sesuai dengan SOP. } \\
\text { 2. Agar } 55 \% \text { petani mengetahui cara } \\
\text { pemeliharaan SPA sesuai dengan } \\
\text { SOP. }\end{array}$ & $\begin{array}{l}\text { 1. Cara pembuatan SPA. } \\
\text { 2. Fungsi dan manfaat SPA } \\
\text { dalam konservasi tanah. } \\
\text { 3. Teknik pemeliharaan SPA } \\
\text { 4. Fungsi dan manfaat } \\
\text { pemeliharaan SPA. }\end{array}$ & Ceramah, diskusi, percontohan \\
\hline 3 & $\begin{array}{l}\text { Bangunan Terjunan Air } \\
\text { Kualitas dan kuantitas bangunan terjunan air } \\
\text { masih sangat kurang }\end{array}$ & $\begin{array}{l}\text { 1. Agar } 50 \% \text { petani mengetahui cara } \\
\text { pembuatan bangunan terjunan air } \\
\text { yang baik dan benar. } \\
\text { 2. Agar } 55 \% \text { petani mengetahui cara } \\
\text { pemeliharaan bangunan terjunan air } \\
\text { yang baik dan benar. }\end{array}$ & $\begin{array}{l}\text { 1. Teknik pembuatan bangunan } \\
\text { terjunan air. } \\
\text { 2. Fungsi dan manfaat bangunan } \\
\text { terjunan air. } \\
\text { 3. Teknik pemeliharaan } \\
\text { bangunan terjunan air }\end{array}$ & Ceramah, diskusi, percontohan \\
\hline 4 & $\begin{array}{l}\text { Dam Penahan/Embung/Gully Plug } \\
\text { Bangunan Dam Penahan belum optimal }\end{array}$ & $\begin{array}{l}\text { 1. Agar } 40 \% \text { petani mengetahui cara } \\
\text { pembuatan Dam Penahan/ embung/ } \\
\text { gullyplug yang baik dan benar. } \\
\text { 2. Agar } 45 \% \text { petani mengetahui cara } \\
\text { pemeliharaan Dam Penahan/ embung/ } \\
\text { gully plug yang baik dan benar. }\end{array}$ & $\begin{array}{l}\text { 1. Teknik pembuatan Gully Plug, } \\
\text { embung, dam penahan. } \\
\text { 2. Teknik pemeliharaan gully } \\
\text { plug, embung, dam penahan. }\end{array}$ & $\begin{array}{l}\text { Ceramah, diskusi, percontohan, } \\
\text { pelatihan }\end{array}$ \\
\hline
\end{tabular}




\begin{tabular}{|c|c|c|c|c|}
\hline No & Keadaan wilayah & Tujuan Penyuluhan & Materi & Metode \\
\hline & \multicolumn{4}{|l|}{ Aspek kelembagaan kelompok tani kehutanan } \\
\hline 1. & $\begin{array}{l}\text { Tingkat kemampuan dan kemandirian anggota } \\
\text { kelompok tani masih rendah }\end{array}$ & $\begin{array}{l}\text { Meningkatkan Perilaku- Konteks-Sikap } \\
\text { petani tentang peran dan fungsi rumpun } \\
\text { kegiatan }\end{array}$ & $\begin{array}{l}\text { 1. Kelompok sebagai wahana } \\
\text { belajar bersama. } \\
\text { 2. Kelompok sebagai unit usaha }\end{array}$ & Ceramah, pendampingan \\
\hline 2. & $\begin{array}{l}\text { Tingkat kemampuan dan kemandirian kelompok } \\
\text { tani dalam penyusunan Participatory Rural } \\
\text { Appraisal (PRA) rendah. }\end{array}$ & $\begin{array}{l}\text { Meningkatkan Perilaku Konteks Sikap } \\
\text { kelompok tani tentang teknik penyususnan } \\
\text { PRA. }\end{array}$ & $\begin{array}{l}\text { 1. Identifikasi potensi wilayah. } \\
\text { 2. Penyusunan Program Desa. }\end{array}$ & Pendampingan kelompok \\
\hline 3. & Manajemen kelompok & $\begin{array}{l}\text { Meningkatkan Perilaku Konteks Sikap } \\
\text { pengurus kelompok tani mengenai } \\
\text { manajemen dan organisasi kelembagaan } \\
\text { petani. }\end{array}$ & $\begin{array}{l}\text { 1. Manajemen kelompok } \\
\text { tanaman hutan/penghijauan } \\
\text { 2. Pembagian tugas dalam } \\
\text { kelompok. }\end{array}$ & Pertemuan \\
\hline 4 & $\begin{array}{l}\text { Kelompok tani belum memiliki Anggaran } \\
\text { Dasar/Anggran Rumah Tangga (AD/ART), } \\
\text { aturan dan sanksi. }\end{array}$ & $\begin{array}{l}\text { Meningkatakan Perilaku Konteks Sikap } \\
\text { pengurus kelompok tani tentang teknik } \\
\text { penyususnan AD/ART, aturan dan sanksi. }\end{array}$ & $\begin{array}{l}\text { 1. Penyusunan Draf AD/ART } \\
\text { 2. Mengenal budaya lokal }\end{array}$ & Pertemuan, pendampingan, diskusi \\
\hline 5 & Legatitas kelompok tani kehutanan masih lemah & $\begin{array}{l}\text { Meningkatkan Perilaku Konteks Sikap } \\
\text { pengurus dan anggota agar memiliki } \\
\text { legalitas }\end{array}$ & $\begin{array}{l}\text { 1. Kelompok tani kehutanan } \\
\text { sebagai lembaga tani yang } \\
\text { sah. } \\
\text { 2. Pengusulan legalitas. }\end{array}$ & Ceramah, pendampingan \\
\hline 6 & $\begin{array}{l}\text { Gabungan/paguyuban kelompok tani kehutanan } \\
\text { dan anggota belum optimal }\end{array}$ & $\begin{array}{l}\text { Meningkatkan Perilaku Konteks Sikap } \\
\text { pengurus kelompok tani tentang } \\
\text { pembentukan gabungan kelompok. }\end{array}$ & $\begin{array}{l}\text { 1. Pendatan kelompok tani } \\
\text { kehutanan } \\
\text { 2. Gabungan kelompok tani } \\
\text { gabungan }\end{array}$ & Diskusi diskusi \\
\hline 7 & $\begin{array}{l}\text { Pembagian tugas pengurus dalam kelompok tani } \\
\text { kehutanan belum ada }\end{array}$ & $\begin{array}{l}\text { Meningkatkan Perilaku Konteks Sikap } \\
\text { pengurus kelompok tani tentang } \\
\text { pembagian tugas di dalam kelompok. }\end{array}$ & $\begin{array}{l}\text { 1. Teknik pembagian tugas } \\
\text { dalam kelompok. }\end{array}$ & Pertemuan, diskusi \\
\hline
\end{tabular}




\begin{tabular}{|c|c|c|c|c|}
\hline No & Keadaan wilayah & Tujuan Penyuluhan & Materi & Metode \\
\hline & Aspek ekonomi Kehutanan & & & \\
\hline 1 & Sistem pemasaran hasil kehutanan masih rendah & $\begin{array}{l}\text { Meningkatkan Perilaku Konteks Sikap } \\
\text { petani tentang sistem pemasaran hasil }\end{array}$ & Teknik sistem pemasaran hasil. & Ceramah, diskusi \\
\hline 2 & Pengembangan usaha produktif masih rendah & $\begin{array}{l}\text { Meningkatkan Perilaku Konteks Sikap } \\
\text { petani tentang penumbuhan kelompok } \\
\text { usaha produktif }\end{array}$ & $\begin{array}{l}\text { Teknik penumbuhan kelompok } \\
\text { usaha produktif }\end{array}$ & $\begin{array}{l}\text { Pertemuan } \\
\text { Demo kelompok usaha produktif } \\
\text { Pendampingan }\end{array}$ \\
\hline 3 & $\begin{array}{l}\text { Pengembangan modal usaha kehutanan masih } \\
\text { rendah }\end{array}$ & $\begin{array}{l}\text { Meningkatkan Perilaku Konteks Sikap } \\
\text { petani tentang permodalan dengan } \\
\text { penumbuhan kopreasi kelompok hutan } \\
\text { rakyat. }\end{array}$ & $\begin{array}{l}\text { 1. Penguatan modal kelompok. } \\
\text { 2. Membangun kemitraan pihak } \\
\text { ke } 3 \text {. }\end{array}$ & $\begin{array}{l}\text { Pertemuan } \\
\text { Pemberdayaan }\end{array}$ \\
\hline 4 & $\begin{array}{l}\text { Pengolahan hasil kayu dan bukan kayu masih } \\
\text { rendah dan terbatas }\end{array}$ & $\begin{array}{l}\text { Meningkatkan Perilaku Konteks Sikap } \\
\text { petani tentang pengolahan hasil hutan. }\end{array}$ & $\begin{array}{l}\text { Teknik pengolahan hasil menjadi } \\
\text { setengah jadi dan atau barang } \\
\text { jadi. }\end{array}$ & $\begin{array}{l}\text { Pelatihan } \\
\text { Temu usaha }\end{array}$ \\
\hline V & Aspek kesejahteraan petani & & & \\
\hline 1 & $\begin{array}{l}\text { Masih terdapat adanya masyarakat yang rawan } \\
\text { pangan sandang, dan papan. }\end{array}$ & $\begin{array}{l}\text { Meningkatkan Perilaku Konteks Sikap } \\
\text { masyarakat desa dalam hal penyediaan } \\
\text { pangan sandang papan yang cukup dan } \\
\text { layak. }\end{array}$ & $\begin{array}{l}\text { 1. Teknik membangun sentra } \\
\text { penyuluhan kehutanan } \\
\text { perdesaan. } \\
\text { 2. Pemberdayaan masyarakat } \\
\text { desa. }\end{array}$ & $\begin{array}{l}\text { Pelatihan } \\
\text { Pendampingan }\end{array}$ \\
\hline
\end{tabular}




\section{Lampiran 2. Keadaan wilayah, tujuan penyuluhan, materi dan metode pada program penyuluhan kehutanan Kabupaten Sumbawa}

\begin{tabular}{|c|c|c|c|c|}
\hline No & Keadaan wilayah & Tujuan Penyuluhan & Materi & Metode \\
\hline 1 & $\begin{array}{l}\text { Tegakan hutan dalam kawasan setiap } \\
\text { tahun makin berkurang akibat kegiatan } \\
\text { illegal logging. }\end{array}$ & $\begin{array}{l}\text { Menumbuhkan kesadaran pelaku utama dan } \\
\text { pelaku usaha dalam menjaga dan melestarikan } \\
\text { kawasan hutan. }\end{array}$ & $\begin{array}{l}\text { UU No. } 18 \text { Tahun } 2013 \text { tentang } \\
\text { pencegahan dan perusakan hutan }\end{array}$ & Ceramah, diskusi \\
\hline 2 & $\begin{array}{l}\text { Kegiatan penanaman dan pemeliharaan } \\
\text { tanaman rehabilitasi lahan di luar dan } \\
\text { dalam kawasan hutan belum optimal }\end{array}$ & $\begin{array}{l}\text { Pelaku utama mau dan mampu menerapkan pola } \\
\text { penanaman dan pemeliharaan tanaman kayu- } \\
\text { kayuan dan Multi Purpose Tree Spesies (MPTs) } \\
\text { sesuai teknis }\end{array}$ & $\begin{array}{l}\text { Teknik penanaman dan } \\
\text { pemeliharaan tanaman kayu dan } \\
\text { MPTs }\end{array}$ & Ceramah,diskusi, demonstrasi \\
\hline 3 & $\begin{array}{l}\text { Potensi Hasil Hutan Bukan Kayu (HHBK) } \\
\text { belum dimanfaatkan secara optimal }\end{array}$ & $\begin{array}{l}\text { Meningkatkan Perilaku- Konteks- Sikap pelaku } \\
\text { utama dalam memanfaatkan dan mengelola HHBK }\end{array}$ & $\begin{array}{l}\text { Jenis - jenis HHBK, pengembangan } \\
\text { dan pengolahan HHBK }\end{array}$ & $\begin{array}{l}\text { Ceramah, diskusi, pelatihan dan praktek } \\
\text { lapangan }\end{array}$ \\
\hline 4 & Sumber mata air semakin berkurang & Menjaga dan memelihara sumber-sumber mata air & $\begin{array}{l}\text { Pemeliharaan dan perlindungan } \\
\text { mata air }\end{array}$ & $\begin{array}{l}\text { Ceramah, diskusi, demontrasi dan } \\
\text { kampanye. }\end{array}$ \\
\hline 5 & $\begin{array}{l}\text { Pengolahan lahan kurang memperhatikan } \\
\text { kaidah konservasi tanah dan air }\end{array}$ & $\begin{array}{l}\text { Meningkatkan Perilaku Konteks Sikap pelaku } \\
\text { utama tentang pengolahan lahan sesuai kaidah } \\
\text { konservasi tanah dan air }\end{array}$ & Teknik konservasi tanah dan air & Ceramah, diskusi, demonstrasi \\
\hline 6 & $\begin{array}{l}\text { Kelembagaan kelompok tani hutan masih } \\
\text { didominasi kelas pemula }\end{array}$ & Peningkatan kelas kelompok tani hutan & $\begin{array}{l}\text { Penguatan kelembagaan dan } \\
\text { pengelolaan kelompok tani hutan. }\end{array}$ & Kunjungan dan studi banding \\
\hline 7 & $\begin{array}{l}\text { Pelaku utama belum memahami prosedur } \\
\text { penatausahaan hasil hutan }\end{array}$ & $\begin{array}{l}\text { Pelaku utama memahami prosedur } \\
\text { penatausahaan hasil hutan }\end{array}$ & $\begin{array}{l}\text { Permenhut No. 30/2012, 41/2014, } \\
42 / 2014,35 / 2012\end{array}$ & Ceramah, diskusi \\
\hline
\end{tabular}

Sumber: Program penyuluhan kehutanan Kabupaten Sumbawa, 2016 



\section{WORKING PAPERS WITH DOIS}

\section{5}

1. Agroforestry in the drylands of eastern Africa: a call to action

2. Biodiversity conservation through agroforestry: managing tree species diversity within a network of community-based, nongovernmental, governmental and research organizations in western Kenya.

3. Invasion of prosopis juliflora and local livelihoods: Case study from the Lake Baringo area of Kenya

4. Leadership for change in farmers organizations: Training report: Ridar Hotel, Kampala, 29th March to 2nd April 2005.

5. Domestication des espèces agroforestières au Sahel : situation actuelle et perspectives

6. Relevé des données de biodiversité ligneuse: Manuel du projet biodiversité des parcs agroforestiers au Sahel

7. Improved land management in the Lake Victoria Basin: TransVic Project's draft report.

8. Livelihood capital, strategies and outcomes in the Taita hills of Kenya

9. Les espèces ligneuses et leurs usages: Les préférences des paysans dans le Cercle de Ségou, au Mali

10. La biodiversité des espèces ligneuses: Diversité arborée et unités de gestion du terroir dans le Cercle de Ségou, au Mali

\section{6}

11. Bird diversity and land use on the slopes of Mt. Kilimanjaro and the adjacent plains, Tanzania

12. Water, women and local social organization in the Western Kenya Highlands

13. Highlights of ongoing research of the World Agroforestry Centre in Indonesia

14. Prospects of adoption of tree-based systems in a rural landscape and its likely impacts on carbon stocks and farmers' welfare: The FALLOW Model Application in Muara Sungkai, Lampung, Sumatra, in a 'Clean Development Mechanism' context

15. Equipping integrated natural resource managers for healthy Agroforestry landscapes.

17. Agro-biodiversity and CGIAR tree and forest science: approaches and examples from Sumatra.

18. Improving land management in eastern and southern Africa: A review of policies.

19. Farm and household economic study of Kecamatan Nanggung, Kabupaten Bogor, Indonesia: A socioeconomic base line study of Agroforestry innovations and livelihood enhancement.

20. Lessons from eastern Africa's unsustainable charcoal business.

21. Evolution of RELMA's approaches to land management: Lessons from two decades of research and development in eastern and southern Africa

22. Participatory watershed management: Lessons from RELMA's work with farmers in eastern Africa.

23. Strengthening farmers' organizations: The experience of RELMA and ULAMP.

24. Promoting rainwater harvesting in eastern and southern Africa.

25. The role of livestock in integrated land management.

26. Status of carbon sequestration projects in Africa: Potential benefits and challenges to scaling up.

27. Social and Environmental Trade-Offs in Tree Species Selection: A Methodology for Identifying Niche Incompatibilities in Agroforestry [Appears as AHI Working Paper no. 9]

28. Managing tradeoffs in agroforestry: From conflict to collaboration in natural resource management. [Appears as AHI Working Paper no. 10]

29. Essai d'analyse de la prise en compte des systemes agroforestiers pa les legislations forestieres au Sahel: Cas du Burkina Faso, du Mali, du Niger et du Senegal.

30. Etat de la recherche agroforestière au Rwanda etude bibliographique, période 1987-2003 
31. Science and technological innovations for improving soil fertility and management in Africa: A report for NEPAD's Science and Technology Forum.

32. Compensation and rewards for environmental services.

33. Latin American regional workshop report compensation.

34. Asia regional workshop on compensation ecosystem services.

35. Report of African regional workshop on compensation ecosystem services.

36. Exploring the inter-linkages among and between compensation and rewards for ecosystem services CRES and human well-being

37. Criteria and indicators for environmental service compensation and reward mechanisms: realistic, voluntary, conditional and pro-poor

38. The conditions for effective mechanisms of compensation and rewards for environmental services.

39. Organization and governance for fostering Pro-Poor Compensation for Environmental Services.

40. How important are different types of compensation and reward mechanisms shaping poverty and ecosystem services across Africa, Asia \& Latin America over the Next two decades?

41. Risk mitigation in contract farming: The case of poultry, cotton, woodfuel and cereals in East Africa.

42. The RELMA savings and credit experiences: Sowing the seed of sustainability

43. Yatich J., Policy and institutional context for NRM in Kenya: Challenges and opportunities for Landcare.

44. Nina-Nina Adoung Nasional di So! Field test of rapid land tenure assessment (RATA) in the Batang Toru Watershed, North Sumatera.

45. Is Hutan Tanaman Rakyat a new paradigm in community based tree planting in Indonesia?

46. Socio-Economic aspects of brackish water aquaculture (Tambak) production in Nanggroe Aceh Darrusalam.

47. Farmer livelihoods in the humid forest and moist savannah zones of Cameroon.

48. Domestication, genre et vulnérabilité : Participation des femmes, des Jeunes et des catégories les plus pauvres à la domestication des arbres agroforestiers au Cameroun.

49. Land tenure and management in the districts around Mt Elgon: An assessment presented to the Mt Elgon ecosystem conservation programme.

50. The production and marketing of leaf meal from fodder shrubs in Tanga, Tanzania: A pro-poor enterprise for improving livestock productivity.

51. Buyers Perspective on Environmental Services (ES) and Commoditization as an approach to liberate ES markets in the Philippines.

52. Towards Towards community-driven conservation in southwest China: Reconciling state and local perceptions.

53. Biofuels in China: An Analysis of the Opportunities and Challenges of Jatropha curcas in Southwest China.

54. Jatropha curcas biodiesel production in Kenya: Economics and potential value chain development for smallholder farmers

55. Livelihoods and Forest Resources in Aceh and Nias for a Sustainable Forest Resource Management and Economic Progress

56. Agroforestry on the interface of Orangutan Conservation and Sustainable Livelihoods in Batang Toru, North Sumatra. 
57. Assessing Hydrological Situation of Kapuas Hulu Basin, Kapuas Hulu Regency, West Kalimantan.

58. Assessing the Hydrological Situation of Talau Watershed, Belu Regency, East Nusa Tenggara.

59. Kajian Kondisi Hidrologis DAS Talau, Kabupaten Belu, Nusa Tenggara Timur.

60. Kajian Kondisi Hidrologis DAS Kapuas Hulu, Kabupaten Kapuas Hulu, Kalimantan Barat.

61. Lessons learned from community capacity building activities to support agroforest as sustainable economic alternatives in Batang Toru orang utan habitat conservation program (Martini, Endri et al.)

62. Mainstreaming Climate Change in the Philippines.

63. A Conjoint Analysis of Farmer Preferences for Community Forestry Contracts in the Sumber Jaya Watershed, Indonesia.

64. The highlands: a shared water tower in a changing climate and changing Asia

65. Eco-Certification: Can It Deliver Conservation and Development in the Tropics.

66. Designing ecological and biodiversity sampling strategies. Towards mainstreaming climate change in grassland management.

67. Towards mainstreaming climate change in grassland management policies and practices on the Tibetan Plateau

68. An Assessment of the Potential for Carbon Finance in Rangelands

69 ECA Trade-offs Among Ecosystem Services in the Lake Victoria Basin.

69. The last remnants of mega biodiversity in West Java and Banten: an in-depth exploration of RaTA (Rapid Land Tenure Assessment) in Mount Halimun-Salak National Park Indonesia

70. Le business plan d'une petite entreprise rurale de production et de commercialisation des plants des arbres locaux. Cas de quatre pépinières rurales au Cameroun.

71. Les unités de transformation des produits forestiers non ligneux alimentaires au Cameroun. Diagnostic technique et stratégie de développement Honoré Tabuna et Ingratia Kayitavu.

72. Les exportateurs camerounais de safou (Dacryodes edulis) sur le marché sous régional et international. Profil, fonctionnement et stratégies de développement.

73. Impact of the Southeast Asian Network for Agroforestry Education (SEANAFE) on agroforestry education capacity.

74. Setting landscape conservation targets and promoting them through compatible land use in the Philippines.

75. Review of methods for researching multistrata systems.

76. Study on economical viability of Jatropha curcas L. plantations in Northern Tanzania assessing farmers' prospects via cost-benefit analysis

77. Cooperation in Agroforestry between Ministry of Forestry of Indonesia and International Center for Research in Agroforestry

78. "China's bioenergy future. an analysis through the Lens if Yunnan Province

79. Land tenure and agricultural productivity in Africa: A comparative analysis of the economics literature and recent policy strategies and reforms

80. Boundary organizations, objects and agents: linking knowledge with action in Agroforestry watersheds

81. Reducing emissions from deforestation and forest degradation (REDD) in Indonesia: options and challenges for fair and efficient payment distribution mechanisms 
82. Mainstreaming climate change into agricultural education: challenges and perspectives

83. Challenging conventional mindsets and disconnects in conservation: the emerging role of ecoagriculture in Kenya's landscape mosaics

84. Lesson learned RATA garut dan bengkunat: suatu upaya membedah kebijakan pelepasan kawasan hutan dan redistribusi tanah bekas kawasan hutan

85. The emergence of forest land redistribution in Indonesia

86. Commercial opportunities for fruit in Malawi

87. Status of fruit production processing and marketing in Malawi

88. Fraud in tree science

89. Trees on farm: analysis of global extent and geographical patterns of agroforestry

90. The springs of Nyando: water, social organization and livelihoods in Western Kenya

91. Building capacity toward region-wide curriculum and teaching materials development in agroforestry education in Southeast Asia

92. Overview of biomass energy technology in rural Yunnan (Chinese - English abstract)

93. A pro-growth pathway for reducing net GHG emissions in China

94. Analysis of local livelihoods from past to present in the central Kalimantan Ex-Mega Rice Project area

95. Constraints and options to enhancing production of high quality feeds in dairy production in Kenya, Uganda and Rwanda

2010

96. Agroforestry education in the Philippines: status report from the Southeast Asian Network for Agroforestry Education (SEANAFE)

97. Economic viability of Jatropha curcas L. plantations in Northern Tanzania- assessing farmers' prospects via cost-benefit analysis.

98. Hot spot of emission and confusion: land tenure insecurity, contested policies and competing claims in the central Kalimantan Ex-Mega Rice Project area

99. Agroforestry competences and human resources needs in the Philippines

100. CES/COS/CIS paradigms for compensation and rewards to enhance environmental Services

101. Case study approach to region-wide curriculum and teaching materials development in agroforestry education in Southeast Asia

102. Stewardship agreement to reduce emissions from deforestation and degradation (REDD): Lubuk Beringin's Hutan Desa as the first village forest in Indonesia

103. Landscape dynamics over time and space from ecological perspective

104. Komoditisasi atau koinvestasi jasa lingkungan: skema imbal jasa lingkungan program peduli sungai di DAS Way Besai, Lampung, Indonesia

105. Improving smallholders' rubber quality in Lubuk Beringin, Bungo district, Jambi province, Indonesia: an initial analysis of the financial and social benefits

106. Rapid Carbon Stock Appraisal (RACSA) in Kalahan, Nueva Vizcaya, Philippines

107. Tree domestication by ICRAF and partners in the Peruvian Amazon: lessons learned and future prospects in the domain of the Amazon Initiative eco-regional program

108. Memorias del Taller Nacional: "Iniciativas para Reducir la Deforestación en la region Andino Amazónica", 09 de Abril del 2010. Proyecto REALU Peru

109. Percepciones sobre la Equidad y Eficiencia en la cadena de valor de REDD en Perú -Reporte de Talleres en Ucayali, San Martín y Loreto, 2009. Proyecto REALU-Perú. 
110. Reducción de emisiones de todos los Usos del Suelo. Reporte del Proyecto REALU Perú Fase 1

111. Programa Alternativas a la Tumba-y-Quema (ASB) en el Perú. Informe Resumen y Síntesis de la Fase II. 2da. versión revisada

112. Estudio de las cadenas de abastecimiento de germoplasma forestal en la amazonía Boliviana

113. Biodiesel in the Amazon

114. Estudio de mercado de semillas forestales en la amazonía Colombiana

115. Estudio de las cadenas de abastecimiento de germoplasma forestal en Ecuador http://dx.doi.org10.5716/WP10340.PDF

116. How can systems thinking, social capital and social network analysis help programs achieve impact at scale?

117. Energy policies, forests and local communities in the Ucayali Region, Peruvian Amazon

118. NTFPs as a Source of Livelihood Diversification for Local Communities in the Batang Toru Orangutan Conservation Program

119. Studi Biodiversitas: Apakah agroforestry mampu mengkonservasi keanekaragaman hayati di DAS Konto?

120. Estimasi Karbon Tersimpan di Lahan-lahan Pertanian di DAS Konto, Jawa Timur

121. Implementasi Kaji Cepat Hidrologi (RHA) di Hulu DAS Brantas, Jawa Timur. http://dx.doi.org/10.5716/WP10338.PDF

122. Kaji Cepat Hidrologi di Daerah Aliran Sungai Krueng Peusangan, NAD,Sumatra http://dx.doi.org/10.5716/WP10337.PDF

123. A Study of Rapid Hydrological Appraisal in the Krueng Peusangan Watershed, NAD, Sumatra. http://dx.doi.org/10.5716/WP10339.PDF

2011

124. An Assessment of farm timber value chains in Mt Kenya area, Kenya

125. A Comparative financial analysis of current land use systems and implications for the adoption of improved agroforestry in the East Usambaras, Tanzania

126. Agricultural monitoring and evaluation systems

127. Challenges and opportunities for collaborative landscape governance in the East Usambara Mountains, Tanzania

128. Transforming Knowledge to Enhance Integrated Natural Resource Management Research, Development and Advocacy in the Highlands of Eastern Africa http://dx.doi.org/10.5716/WP11084.PDF

129. Carbon-forestry projects in the Philippines: potential and challenges The Mt Kitanglad Range forestcarbon development http://dx.doi.org10.5716/WP11054.PDF

130. Carbon forestry projects in the Philippines: potential and challenges. The Arakan Forest Corridor forest-carbon project. http://dx.doi.org10.5716/WP11055.PDF

131. Carbon-forestry projects in the Philippines: potential and challenges. The Laguna Lake Development Authority's forest-carbon development project. http://dx.doi.org/10.5716/WP11056.PDF

132. Carbon-forestry projects in the Philippines: potential and challenges. The Quirino forest-carbon development project in Sierra Madre Biodiversity Corridor http://dx.doi.org10.5716/WP11057.PDF

133. Carbon-forestry projects in the Philippines: potential and challenges. The Ikalahan Ancestral Domain forest-carbon development http://dx.doi.org10.5716/WP11058.PDF

134. The Importance of Local Traditional Institutions in the Management of Natural Resources in the Highlands of Eastern Africa. http://dx.doi.org/10.5716/WP11085.PDF 
135. Socio-economic assessment of irrigation pilot projects in Rwanda. http://dx.doi.org/10.5716/WP11086.PDF

136. Performance of three rambutan varieties (Nephelium lappaceum L.) on various nursery media. http://dx.doi.org/10.5716/WP11232.PDF

137. Climate change adaptation and social protection in agroforestry systems: enhancing adaptive capacity and minimizing risk of drought in Zambia and Honduras http://dx.doi.org/10.5716/WP11269.PDF

138. Does value chain development contribute to rural poverty reduction? Evidence of asset building by smallholder coffee producers in Nicaragua http://dx.doi.org/10.5716/WP11271.PDF

139. Potential for biofuel feedstock in Kenya. http://dx.doi.org/10.5716/WP11272.PDF

140. Impact of fertilizer trees on maize production and food security in six districts of Malawi. http://dx.doi.org/10.5716/WP11281.PDF

\section{2}

141. Fortalecimiento de capacidades para la gestión del Santuario Nacional Pampa Hermosa:

Construyendo las bases para un manejo adaptativo para el desarrollo local. Memorias del Proyecto. http://dx.doi.org/10.5716/WP12005.PDF

142. Understanding rural institutional strengthening: A cross-level policy and institutional framework for sustainable development in Kenya http://dx.doi.org/10.5716/WP12012.PDF

143. Climate change vulnerability of agroforestry http://dx.doi.org/10.5716/WP16722.PDF

144. Rapid assesment of the inner Niger delta of Mali http://dx.doi.org/10.5716/WP12021.PDF

145. Designing an incentive program to reduce on-farm deforestationin the East Usambara Mountains, Tanzania http://dx.doi.org/10.5716/WP12048.PDF

146. Extent of adoption of conservation agriculture and agroforestry in Africa: the case of Tanzania, Kenya, Ghana, and Zambia http://dx.doi.org/10.5716/WP12049.PDF

147. Policy incentives for scaling up conservation agriculture with trees in Africa: the case of Tanzania, Kenya, Ghana and Zambia http://dx.doi.org/10.5716/WP12050.PDF

148. Commoditized or co-invested environmental services? Rewards for environmental services scheme: River Care program Way Besai watershed, Lampung, Indonesia. http://dx.doi.org/10.5716/WP12051.PDF

149. Assessment of the headwaters of the Blue Nile in Ethiopia. http://dx.doi.org/10.5716/WP12160.PDF

150. Assessment of the uThukela Watershed, Kwazaulu. http://dx.doi.org/10.5716/WP12161.PDF

151. Assessment of the Oum Zessar Watershed of Tunisia. http://dx.doi.org/10.5716/WP12162.PDF

152. Assessment of the Ruwenzori Mountains in Uganda. http://dx.doi.org/10.5716/WP12163.PDF

153. History of agroforestry research and development in Viet Nam. Analysis of research opportunities and gaps. http://dx.doi.org/10.5716/WP12052.PDF

154. REDD+ in Indonesia: a Historical Perspective. http://dx.doi.org/10.5716/WP12053.PDF

155. Agroforestry and Forestry in Sulawesi series: Livelihood strategies and land use system dynamics in South Sulawesi http://dx.doi.org/10.5716/WP12054.PDF

156. Agroforestry and Forestry in Sulawesi series: Livelihood strategies and land use system dynamics in Southeast Sulawesi. http://dx.doi.org/10.5716/WP12055.PDF

157. Agroforestry and Forestry in Sulawesi series: Profitability and land-use systems in South and Southeast Sulawesi. http://dx.doi.org/10.5716/WP12056.PDF

158. Agroforestry and Forestry in Sulawesi series: Gender, livelihoods and land in South and Southeast Sulawesi http://dx.doi.org/10.5716/WP12057.PDF 
159. Agroforestry and Forestry in Sulawesi series: Agroforestry extension needs at the community level in AgFor project sites in South and Southeast Sulawesi, Indonesia. http://dx.doi.org/10.5716/WP12058.PDF

160. Agroforestry and Forestry in Sulawesi series: Rapid market appraisal of agricultural, plantation and forestry commodities in South and Southeast Sulawesi. http://dx.doi.org/10.5716/WP12059.PDF

\section{3}

161. Diagnosis of farming systems in the Agroforestry for Livelihoods of Smallholder farmers in Northwestern Viet Nam project http://dx.doi.org/10.5716/WP13033.PDF

162. Ecosystem vulnerability to climate change: a literature review. http://dx.doi.org/10.5716/WP13034.PDF

163. Local capacity for implementing payments for environmental services schemes: lessons from the RUPES project in northeastern Viet Nam http://dx.doi.org/10.5716/WP13046.PDF

164. Seri Agroforestri dan Kehutanan di Sulawesi: Agroforestry dan Kehutanan di Sulawesi: Strategi mata pencaharian dan dinamika sistem penggunaan lahan di Sulawesi Selatan http://dx.doi.org/10.5716/WP13040.PDF

165. Seri Agroforestri dan Kehutanan di Sulawesi: Mata pencaharian dan dinamika sistem penggunaan lahan di Sulawesi Tenggara http://dx.doi.org/10.5716/WP13041.PDF

166. Seri Agroforestri dan Kehutanan di Sulawesi: Profitabilitas sistem penggunaan lahan di Sulawesi Selatan dan Sulawesi Tenggara http://dx.doi.org/10.5716/WP13042.PDF

167. Seri Agroforestri dan Kehutanan di Sulawesi: Gender, mata pencarian dan lahan di Sulawesi Selatan dan Sulawesi Tenggara http://dx.doi.org/10.5716/WP13043.PDF

168. Seri Agroforestri dan Kehutanan di Sulawesi: Kebutuhan penyuluhan agroforestri pada tingkat masyarakat di lokasi proyek AgFor di Sulawesi Selatan dan Tenggara, Indonesia. http://dx.doi.org/10.5716/WP13044.PDF

169. Seri Agroforestri dan Kehutanan di Sulawesi: Laporan hasil penilaian cepat untuk komoditas pertanian, perkebunan dan kehutanan di Sulawesi Selatan dan Tenggara http://dx.doi.org/10.5716/WP13045.PDF

170. Agroforestry, food and nutritional security http://dx.doi.org/10.5716/WP13054.PDF

171. Stakeholder Preferences over Rewards for Ecosystem Services: Implications for a REDD+ Benefit Distribution System in Viet Nam http://dx.doi.org/10.5716/WP13057.PDF

172. Payments for ecosystem services schemes: project-level insights on benefits for ecosystems and the rural poor http://dx.doi.org/10.5716/WP13001.PDF

173. Good practices for smallholder teak plantations: keys to success http://dx.doi.org/10.5716/WP13246.PDF

174. Market analysis of selected agroforestry products in the Vision for Change Project intervention Zone, Côte d'Ivoire http://dx.doi.org/10.5716/WP13249.PDF

175. Rattan futures in Katingan: why do smallholders abandon or keep their gardens in Indonesia's 'rattan district'? http://dx.doi.org/10.5716/WP13251.PDF

176. Management along a gradient: the case of Southeast Sulawesi's cacao production landscapes http://dx.doi.org/10.5716/WP13265.PDF 
177. Are trees buffering ecosystems and livelihoods in agricultural landscapes of the Lower Mekong Basin? Consequences for climate-change adaptation. http://dx.doi.org/10.5716/WP14047.PDF

178. Agroforestry, livestock, fodder production and climate change adaptation and mitigation in East Africa: issues and options. http://dx.doi.org/10.5716/WP14050.PDF

179. Trees on farms: an update and reanalysis of agroforestry's global extent and socio-ecological characteristics. http://dx.doi.org/10.5716/WP14064.PDF

180. Beyond reforestation: an assessment of Vietnam's REDD+ readiness. http://dx.doi.org/10.5716/WP14097.PDF

181. Farmer-to-farmer extension in Kenya: the perspectives of organizations using the approach. http://dx.doi.org/10.5716/WP14380.PDF

182. Farmer-to-farmer extension in Cameroon: a survey of extension organizations. http://dx.doi.org/10.5716/WP14383.PDF

183. Farmer-to-farmer extension approach in Malawi: a survey of organizations: a survey of organizations http://dx.doi.org/10.5716/WP14391.PDF

184. Seri Agroforestri dan Kehutanan di Sulawesi: Kuantifikasi jasa lingkungan air dan karbon pola agroforestri pada hutan rakyat di wilayah sungai Jeneberang

185. Options for Climate-Smart Agriculture at Kaptumo Site in Kenyahttp://dx.doi.org/10.5716/WP14394.PDF

\section{5}

186. Agroforestry for Landscape Restoration and Livelihood Development in Central Asia http://dx.doi.org/10.5716/WP14143.PDF

187. "Projected Climate Change and Impact on Bioclimatic Conditions in the Central and South-Central Asia Region" http://dx.doi.org/10.5716/WP14144.PDF

188. Land Cover Changes, Forest Loss and Degradation in Kutai Barat, Indonesia. http://dx.doi.org/10.5716/WP14145.PDF

189. The Farmer-to-Farmer Extension Approach in Malawi: A Survey of Lead Farmers. http://dx.doi.org/10.5716/WP14152.PDF

190. Evaluating indicators of land degradation and targeting agroforestry interventions in smallholder farming systems in Ethiopia. http://dx.doi.org/10.5716/WP14252.PDF

191. Land health surveillance for identifying land constraints and targeting land management options in smallholder farming systems in Western Cameroon

192. Land health surveillance in four agroecologies in Malawi

193. Cocoa Land Health Surveillance: an evidence-based approach to sustainable management of cocoa landscapes in the Nawa region, South-West Côte d'Ivoire http://dx.doi.org/10.5716/WP14255.PDF

194. Situational analysis report: Xishuangbanna autonomous Dai Prefecture, Yunnan Province, China. http://dx.doi.org/10.5716/WP14255.PDF

195. Farmer-to-farmer extension: a survey of lead farmers in Cameroon. http://dx.doi.org/10.5716/WP15009.PDF

196. From transition fuel to viable energy source Improving sustainability in the sub-Saharan charcoal sector http://dx.doi.org/10.5716/WP15011.PDF

197. Mobilizing Hybrid Knowledge for More Effective Water Governance in the Asian Highlands http://dx.doi.org/10.5716/WP15012.PDF

198. Water Governance in the Asian Highlands http://dx.doi.org/10.5716/WP15013.PDF

199. Assessing the Effectiveness of the Volunteer Farmer Trainer Approach in Dissemination of Livestock Feed Technologies in Kenya vis-à-vis other Information Sources

http://dx.doi.org/10.5716/WP15022.PDF 
200. The rooted pedon in a dynamic multifunctional landscape: Soil science at the World Agroforestry Centre http://dx.doi.org/10.5716/WP15023.PDF

201. Characterising agro-ecological zones with local knowledge. Case study: Huong Khe district, Ha Tinh, Viet Nam http://dx.doi.org/10.5716/WP15050.PDF

202. Looking back to look ahead: Insight into the effectiveness and efficiency of selected advisory approaches in the dissemination of agricultural technologies indicative of Conservation Agriculture with Trees in Machakos County, Kenya. http://dx.doi.org/10.5716/WP15065.PDF

203. Pro-poor Biocarbon Projects in Eastern Africa Economic and Institutional Lessons. http://dx.doi.org/10.5716/WP15022.PDF

204. Projected climate change impacts on climatic suitability and geographical distribution of banana and coffee plantations in Nepal. http://dx.doi.org/10.5716/WP15294.PDF

205. Agroforestry and Forestry in Sulawesi series: Smallholders' coffee production and marketing in Indonesia. A case study of two villages in South Sulawesi Province. http://dx.doi.org/10.5716/WP15690.PDF

206. Mobile phone ownership and use of short message service by farmer trainers: a case study of Olkalou and Kaptumo in Kenya http://dx.doi.org/10.5716/WP15691.PDF

207. Associating multivariate climatic descriptors with cereal yields: a case study of Southern Burkina Faso http://dx.doi.org/10.5716/WP15273.PDF

208. Preferences and adoption of livestock feed practices among farmers in dairy management groups in Kenya http://dx.doi.org/10.5716/WP15675.PDF

209. Scaling up climate-smart agriculture: lessons learned from South Asia and pathways for success http://dx.doi.org/10.5716/WP15720.PDF

210. Agroforestry and Forestry in Sulawesi series: Local perceptions of forest ecosystem services and collaborative formulation of reward mechanisms in South and Southeast Sulawesi http://dx.doi.org/10.5716/WP15721.PDF

211. Potential and challenges in implementing the co-investment of ecosystem services scheme in Buol District, Indonesia. http://dx.doi.org/10.5716/WP15722.PDF

212. Tree diversity and its utilization by the local community in Buol District, Indonesia http://dx.doi.org/10.5716/WP15723.PDF

213 Vulnerability of smallholder farmers and their preferences on farming practices in Buol District, Indonesia http://dx.doi.org/10.5716/WP15724.PDF

214. Dynamics of Land Use/Cover Change and Carbon Emission in Buol District, Indonesia http://dx.doi.org/10.5716/WP15725.PDF

215. Gender perspective in smallholder farming practices in Lantapan, Phillippines. http://dx.doi.org/10.5716/WP15726.PDF

216. Vulnerability of smallholder farmers in Lantapan, Bukidnon. http://dx.doi.org/10.5716/WP15727.PDF

217. Vulnerability and adaptive capacity of smallholders in Ho Ho sub-watershed, north-central Viet Nam http://dx.doi.org/10.5716/WP15728.PDF

218. Local knowledge on the role of trees to enhance livelihoods and ecosystem services in Ho Ho Subwatershed, north-central Viet Nam http://dx.doi.org/10.5716/WP15729.PDF

219. Landuse/cover change in Ho Ho Sub-watershed, north-central Viet Nam. http://dx.doi.org/10.5716/WP15730.PDF 
220. Agroforestry and Forestry in Sulawesi series: Evaluation of the Agroforestry Farmer Field Schools on agroforestry management in South and Southeast Sulawesi, Indonesia.

http://dx.doi.org/10.5716/WP16002.PDF

221 Farmer-to-farmer extension of livestock feed technologies in Rwanda: A survey of volunteer farmer trainers and organizations. http://dx.doi.org/10.5716/WP16005.PDF

222 Projected Climate Change Impact on Hydrology, Bioclimatic Conditions, and Terrestrial Ecosystems in the Asian Highlands http://dx.doi.org/10.5716/WP16006.PDF

223 Adoption of Agroforestry and its impact on household food security among farmers in Malawi http://dx.doi.org/10.5716/WP16013.PDF

224 Agroforestry and Forestry in Sulawesi series: Information channels for disseminating innovative agroforestry practices to villages in Southern Sulawesi, Indonesia http://dx.doi.org/10.5716/WP16034.PDF

225 Agroforestry and Forestry in Sulawesi series: Unravelling rural migration networks.Land-tenure arrangements among Bugis migrant communities in Southeast Sulawesi. http://dx.doi.org/10.5716/WP16035.PDF

226 Agroforestry and Forestry in Sulawesi series: Women's participation in agroforestry: more benefit or burden? A gendered analysis of Gorontalo Province. http://dx.doi.org/10.5716/WP16036.PDF

227 Kajian Kelayakan dan Pengembangan Desain Teknis Rehabilitasi Pesisir di Sulawesi Tengah. http://dx.doi.org/10.5716/WP16037.PDF

228. Selection of son tra clones in North West Vietnam. http://dx.doi.org/10.5716/WP16038.PDF

229. Growth and fruit yield of seedlings, cuttings and grafts from selected son tra trees in Northwest Vietnam http://dx.doi.org/10.5716/WP16046.PDF

230. Gender-Focused Analysis of Poverty and Vulnerability in Yunnan, China. http://dx.doi.org/10.5716/WP16071.PDF

231. Seri Agroforestri dan Kehutanan di Sulawesi: Kebutuhan Penyuluhan Agroforestri untuk Rehabilitasi Lahan di Sumba Timur, Nusa Tenggara Timur, Indonesia.http://dx.doi.org/10.5716/WP16077.PDF

232. Agroforestry and Forestry in Sulawesi series: Agroforestry extension needs for land rehabilitation in East Sumba, East Nusa Tenggara, Indonesia. http://dx.doi.org/10.5716/WP16078.PDF

233. Central hypotheses for the third agroforestry paradigm within a common definition. http://dx.doi.org/10.5716/WP16079.PDF

234. Assessing smallholder farmers' interest in shade coffee trees: The Farming Systems of Smallholder Coffee Producers in the Gisenyi Area, Rwanda: a participatory diagnostic study. http://dx.doi.org/10.5716/WP16104.PDF

235. Review of agricultural market information systems in |sub-Saharan Africa. http://dx.doi.org/10.5716/WP16110.PDF

236. Vision and road map for establishment of a protected area in Lag Badana, Lower Jubba, Somalia. http://dx.doi.org/10.5716/WP16127.PDF

237. Replicable tools and frameworks for Bio-Carbon Development in West Africa. http://dx.doi.org/10.5716/WP16138.PDF

238. Existing Conditions, Challenges and Needs in the Implementation of Forestry and Agroforestry Extension in Indonesia. http://dx.doi.org/10.5716/WP16141.PDF

239. Situasi Terkini, Tantangan dan Kebutuhan Pelaksanaan Penyuluhan Kehutanan dan Agroforestri di Indonesia. http://dx.doi.org/10.5716/WP16142.PDF 

The World Agroforestry Centre is an autonomous, non-profit research organization whose vision is a rural transformation in the developing world as smallholder households increase their use of trees in agricultural landscapes to improve food security, nutrition, income, health, shelter, social cohesion, energy resources and environmental sustainability. The Centre generates science-based knowledge about the diverse roles that trees play in agricultural landscapes, and uses its research to advance policies and practices, and their implementation that benefit the poor and the environment. It aims to ensure that all this is achieved by enhancing the quality of its science work, increasing operational efficiency, building and maintaining strong partnerships, accelerating the use and impact of its research, and promoting greater cohesion, interdependence and alignment within the organization.

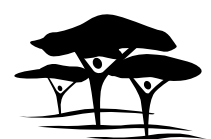

United Nations Avenue, Gigiri • PO Box 30677 • Nairobi, $00100 \cdot$ Kenya Telephone: +254 207224000 or via USA +1 6508336645 Fax: +254207224001 or via USA +1 6508336646

Email: worldagroforestry@cgiar.org•www.worldagroforestry.org

Southeast Asia Regional Program • Sindang Barang • Bogor 16680

PO Box $161 \cdot$ Bogor $16001 \cdot$ Indonesia

Telephone: +62 2518625415 • Fax: +62 2518625416

- Email: icraf-indonesia@cgiar.org

www.worldagroforestry.org/region/southeast-asia

blog.worldagroforestry.org 